\title{
Deposit Model for Heavy-Mineral Sands in Coastal Environments
}

Chapter L of

Mineral Deposit Models for Resource Assessment

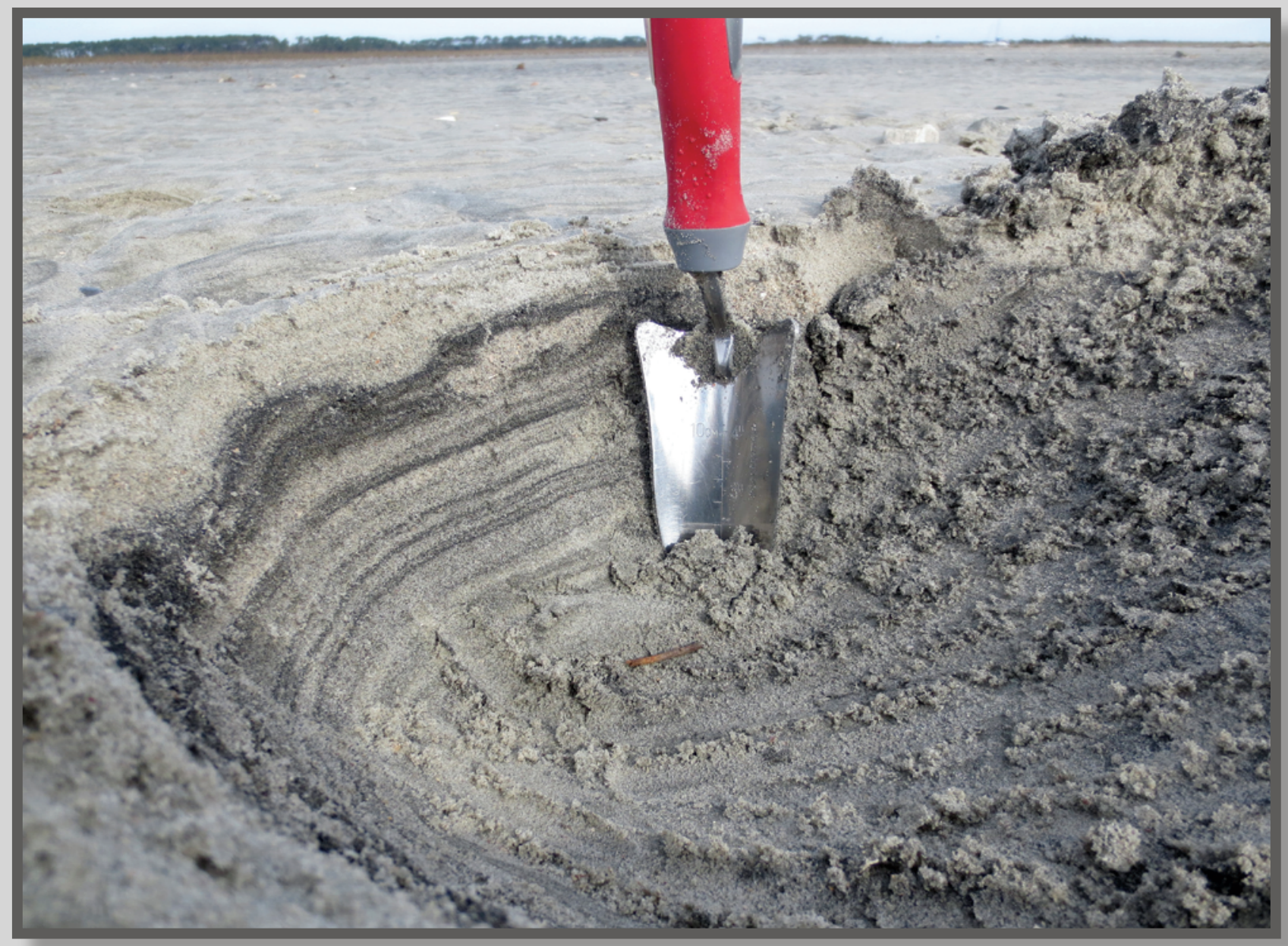

Scientific Investigations Report 2010-5070-L 
COVER. Layered deposit of heavy-mineral sands in a modern beach at Folly Beach, South Carolina.

Photograph by Carleton Bern, U.S. Geological Survey, February 2013. 


\section{Deposit Model for Heavy-Mineral Sands in Coastal Environments}

By Bradley S. Van Gosen, David L. Fey, Anjana K. Shah, Philip L. Verplanck, and Todd M. Hoefen

Chapter L of

Mineral Deposit Models for Resource Assessment

Scientific Investigations Report 2010-5070-L 


\section{U.S. Department of the Interior \\ SALLY JEWELL, Secretary \\ U.S. Geological Survey \\ Suzette M. Kimball, Acting Director}

U.S. Geological Survey, Reston, Virginia: 2014

For more information on the USGS - the Federal source for science about the Earth, its natural and living resources, natural hazards, and the environment, visit http://www.usgs.gov or call 1-888-ASK-USGS.

For an overview of USGS information products, including maps, imagery, and publications, visit http://www.usgs.gov/pubprod

To order this and other USGS information products, visit http://store.usgs.gov

Any use of trade, firm, or product names is for descriptive purposes only and does not imply endorsement by the U.S. Government.

Although this information product, for the most part, is in the public domain, it also may contain copyrighted materials as noted in the text. Permission to reproduce copyrighted items must be secured from the copyright owner.

Suggested citation:

Van Gosen, B.S., Fey, D.L., Shah, A.K., Verplanck, P.L., and Hoefen, T.M., 2014, Deposit model for heavy-mineral sands in coastal environments: U.S. Geological Survey Scientific Investigations Report 2010-5070-L, 51 p., http://dx.doi.org/10.3133/sir20105070L.

ISSN 2328-0328 (online) 


\section{Contents}

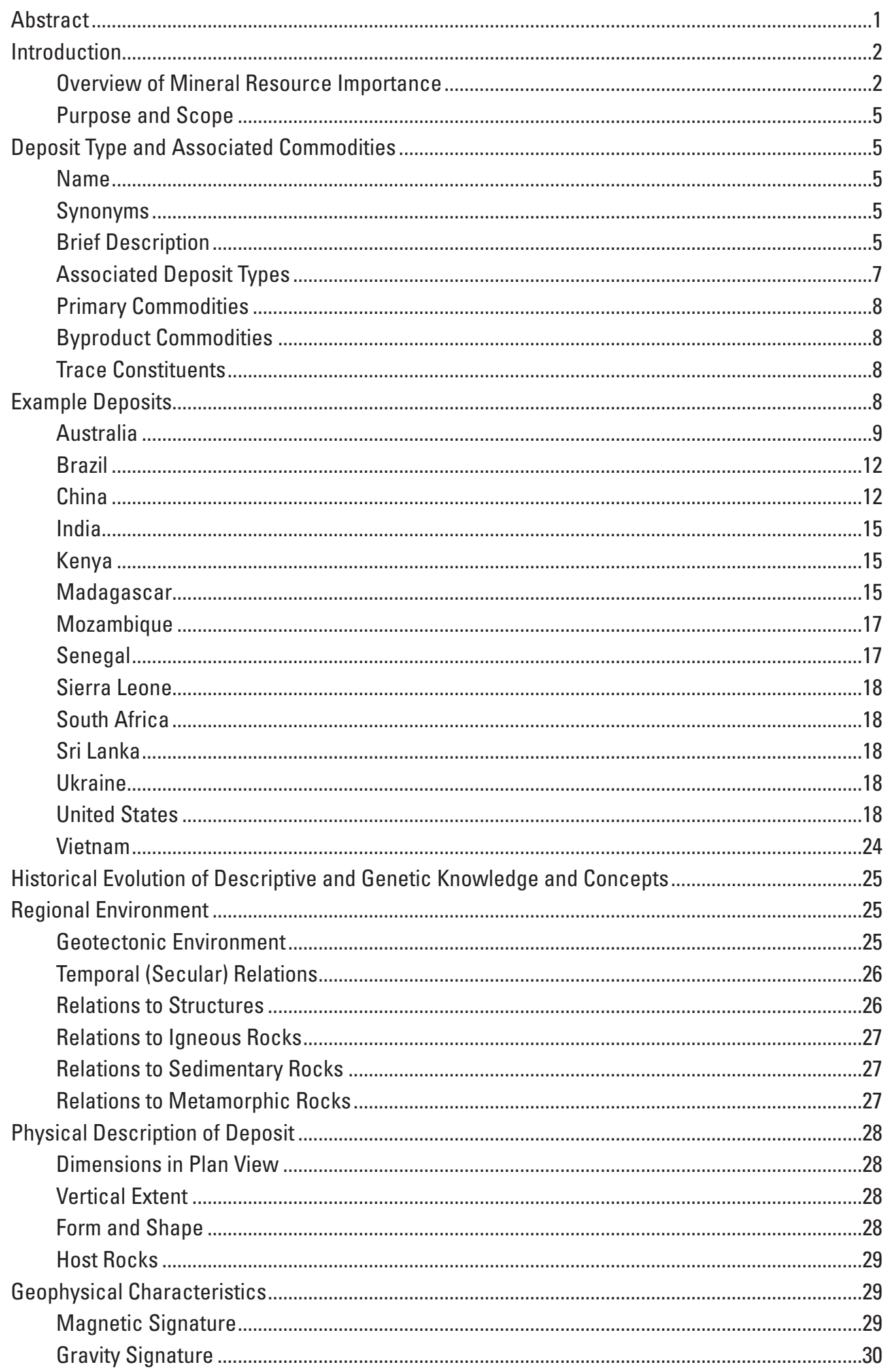




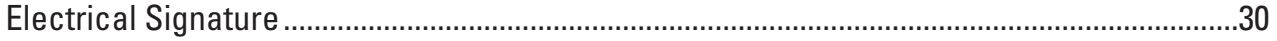

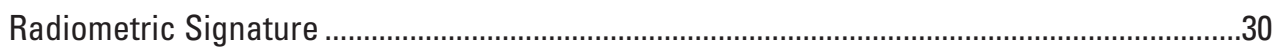

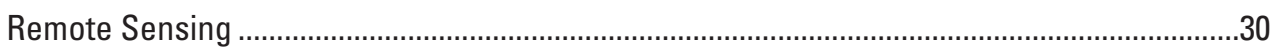

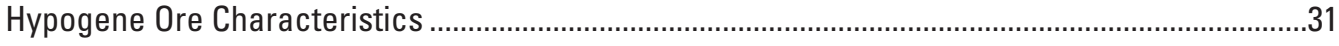

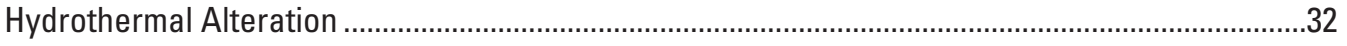

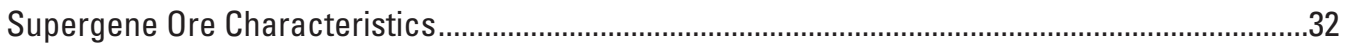

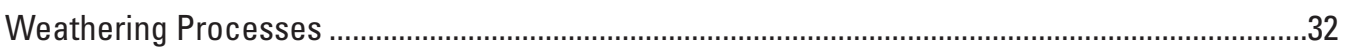

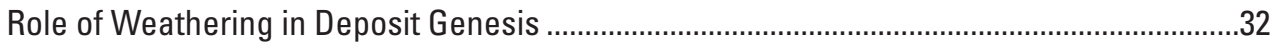

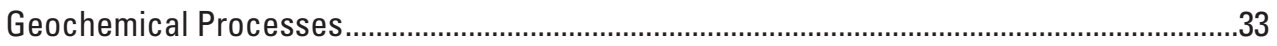

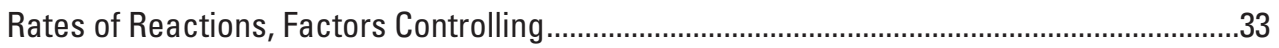

Effects of Microclimates and Macroclimates ……...........................................................3

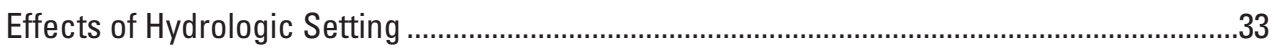

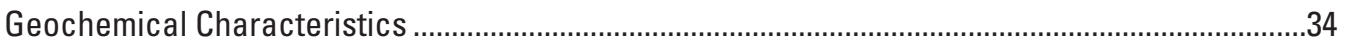

Trace Elements and Element Associations ......................................................................

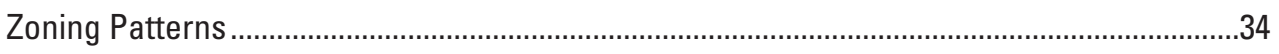

Fluid-Inclusion Thermometry and Geochemistry ……...................................................34

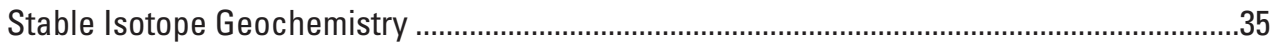

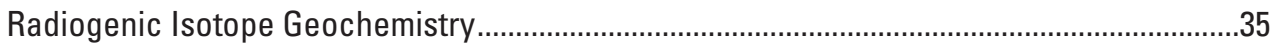

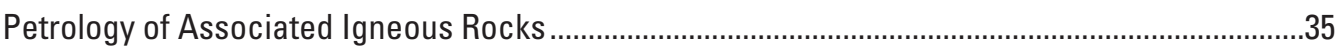

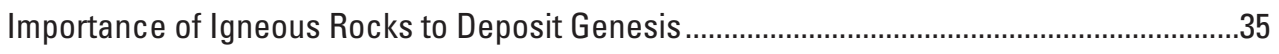

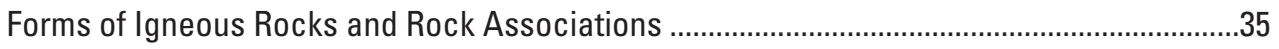

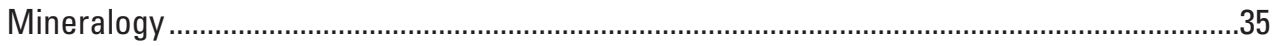

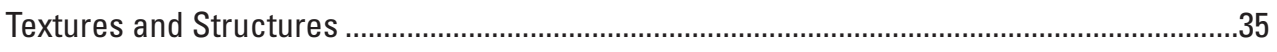

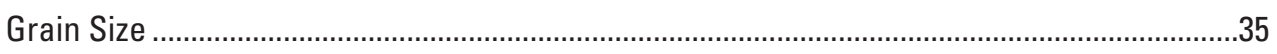

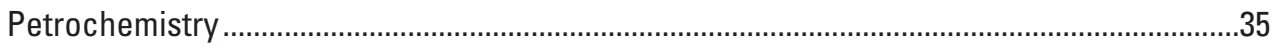

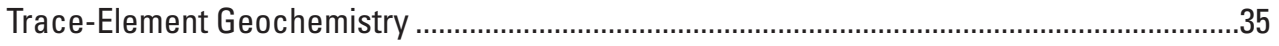

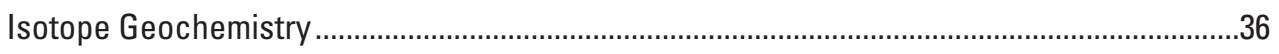

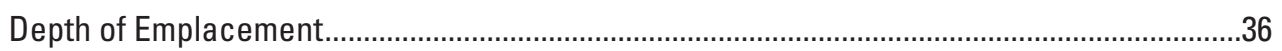

Petrology of Associated Sedimentary Rocks.............................................................................

Importance of Sedimentary Rocks to Deposit Genesis........................................................36

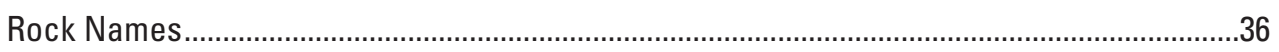

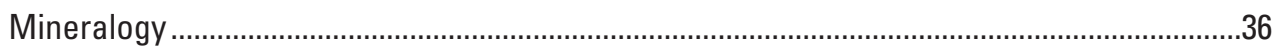

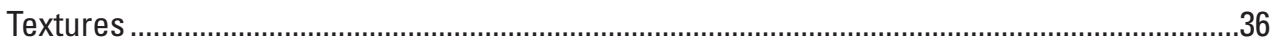

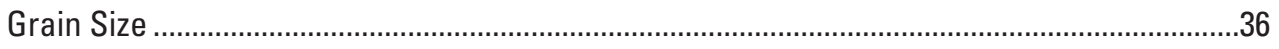

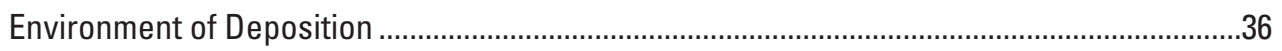

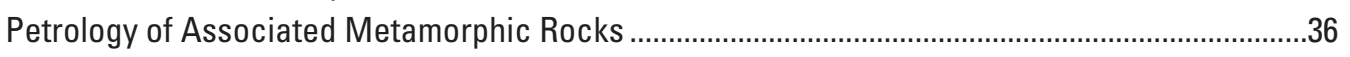

Importance of Metamorphic Rocks to Deposit Genesis ........................................................

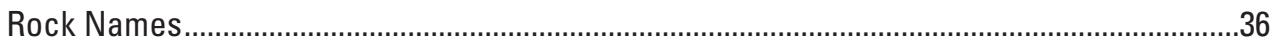

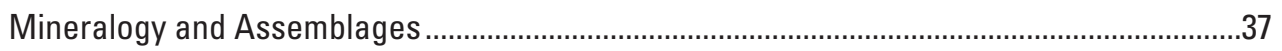

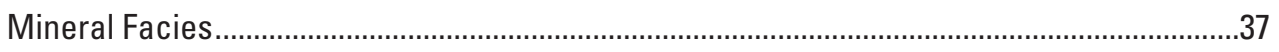

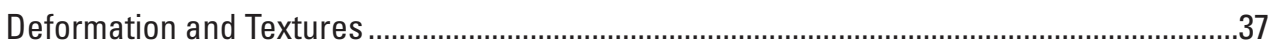

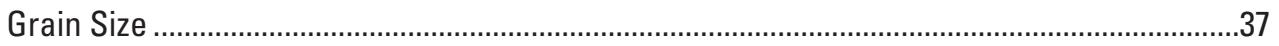

Environment of Deposition ............................................................................................

Theory of Deposit Formation...........................................................................................

Exploration and Resource Assessment Guides .........................................................................38 


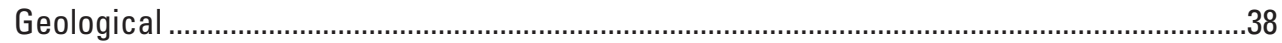

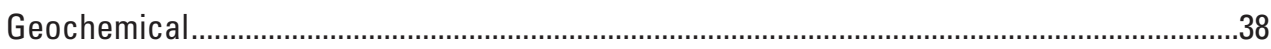

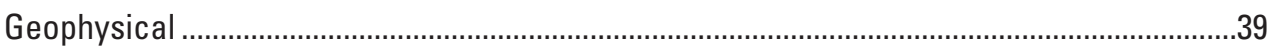

Attributes Required for Inclusion in Permissive Tracts at Various Scales ..............................39

Knowledge That Enables Favorability Zonation of Permissive Tracts .....................................39

Factors Influencing Estimates of Size and Density of Undiscovered Deposits.......................40

Geoenvironmental Features and Effects of Mining ...................................................................... 40

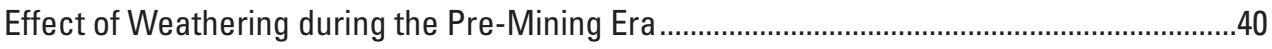

Pre-Mining Baseline Signatures in Soil, Sediment, and Water ................................................40

Past and Potential Future Mining Methods and Ore Treatment ...............................................40

Volume of Mine Waste and Tailings and Sizes of Operations................................................41

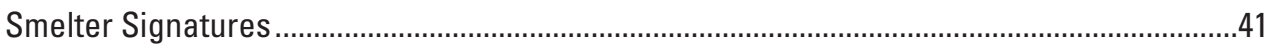

Mine Waste Characteristics ............................................................................................

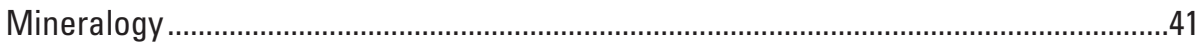

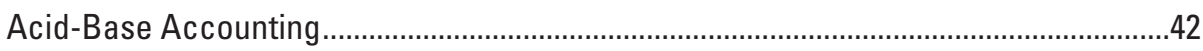

Geochemical Characteristics .....................................................................................

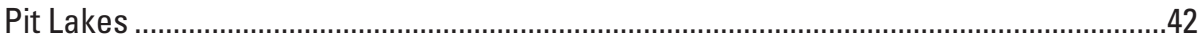

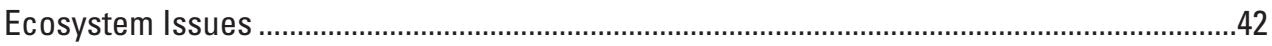

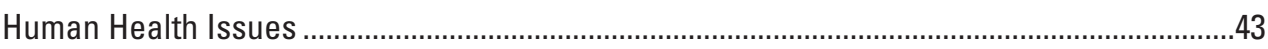

Climate Effects on Geoenvironmental Signatures ...............................................................4

Knowledge Gaps and Future Research Directions ......................................................................

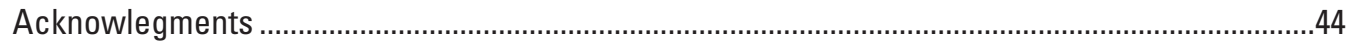

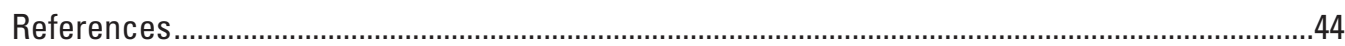

\section{Figures}

1. Photograph of heavy-mineral layers ("black sand") in quartz beach sand, Chennai,

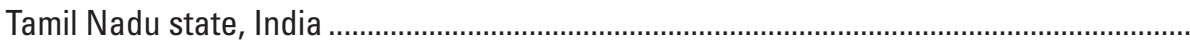

2. Photograph of an area of Assateague Island, Maryland, before and after Hurricane Sandy (October 28-30, 2012).

3. Schematic cross-section showing features commonly used to describe shoreline (strandline) depositional environments associated with deposits of heavy-mineral sands

4. Index map of Australian Cenozoic sedimentary basins and other districts (Tiwi Islands, Cape York, North Stradbroke Island) hosting deposits of heavy-mineral sands that were being mined as of 2013 .

5. Index map of central coastline of Brazil showing monazite-producing placer deposits

6. Index map of southernmost China showing selected monazite-bearing placer districts.

7. Index map of southern India and northern Sri Lanka showing locations of historical and active heavy-mineral sands operations discussed in this report and areas of Quaternary and Neogene sediments

8. Index map of Africa showing locations of active heavy-mineral-sands operations and advanced projects that are discussed in this report

9. Index map of southwestern Sri Lanka showing the Bentota Ganga River 
10. Index map of southeastern United States showing the extent of Late Cretaceous and Tertiary (Paleogene and Neogene) sediments in the coastal plain of this region...........20

11. Photograph of the Concord heavy-mineral-sands mine in south-central Virginia..........21

12. Index map showing locations of heavy-mineral-sands samples and mines in southeastern Georgia and northeastern Florida .............................................................22

13. Map of the Lakehurst area, New Jersey, showing locations of former heavymineral-sands mines

14. Index map showing extent of the Late Cretaceous McNairy Sand in the area surrounding Bruceton, western Tennessee.

15. Map of southeastern Vietnam outlining the general area containing the largest, most productive heavy-mineral-sands deposits in Vietnam

16. Diagram of reflectance of quartz sand sample GDS74 showing the mid-infrared region of the spectrum.

17. Diagram of reflectance showing quartz sand, zircon, monazite and ilmenite spectra in the visible to near-infrared range.

18. Chondrite-normalized plot showing the rare earth element distribution in selected monazites separated from heavy-mineral-sands deposits in four regions: Asia, North America, India, and Australia....

19. Photograph of a truck-mounted rotary drill designed to sample unconsolidated sediments

\section{Table}

1. Common minerals in heavy-mineral sands deposits 


\section{Conversion Factors}

Inch/Pound to SI

\begin{tabular}{|c|c|c|}
\hline Multiply & By & To obtain \\
\hline & Length & \\
\hline inch (in.) & 25.4 & millimeter (mm) \\
\hline foot $(\mathrm{ft})$ & 0.3048 & meter $(\mathrm{m})$ \\
\hline mile (mi) & 1.609 & kilometer $(\mathrm{km})$ \\
\hline \multirow[t]{2}{*}{$\operatorname{yard}(\mathrm{yd})$} & 0.9144 & meter $(\mathrm{m})$ \\
\hline & Area & \\
\hline acre & 0.4047 & hectare (ha) \\
\hline \multirow[t]{2}{*}{ square mile $\left(\mathrm{mi}^{2}\right)$} & 259.0 & hectare (ha) \\
\hline & Volume & \\
\hline \multirow[t]{2}{*}{ cubic yard $\left(\mathrm{yd}^{3}\right)$} & 0.7646 & cubic meter $\left(\mathrm{m}^{3}\right)$ \\
\hline & Density & \\
\hline pound per cubic foot $\left(\mathrm{lb} / \mathrm{ft}^{3}\right)$ & 0.01602 & $\begin{array}{l}\text { gram per cubic centimeter } \\
\qquad\left(\mathrm{g} / \mathrm{cm}^{3}\right)\end{array}$ \\
\hline \multicolumn{3}{|l|}{ SI to Inch/Pound } \\
\hline \multirow[t]{2}{*}{ Multiply } & By & To obtain \\
\hline & Length & \\
\hline millimeter $(\mathrm{mm})$ & 0.03937 & inch (in.) \\
\hline meter $(\mathrm{m})$ & 3.281 & foot $(\mathrm{ft})$ \\
\hline kilometer $(\mathrm{km})$ & 0.6214 & mile (mi) \\
\hline \multirow[t]{2}{*}{ meter $(\mathrm{m})$} & 1.094 & yard (yd) \\
\hline & Area & \\
\hline hectare (ha) & 2.471 & acre \\
\hline \multirow[t]{2}{*}{ hectare (ha) } & 0.003861 & square mile $\left(\mathrm{mi}^{2}\right)$ \\
\hline & Volume & \\
\hline \multirow[t]{2}{*}{ cubic meter $\left(\mathrm{m}^{3}\right)$} & 264.2 & gallon (gal) \\
\hline & Density & \\
\hline $\begin{array}{l}\text { gram per cubic centimeter } \\
\qquad\left(\mathrm{g} / \mathrm{cm}^{3}\right)\end{array}$ & 62.4220 & $\begin{array}{l}\text { pound per cubic foot } \\
\left(\mathrm{lb} / \mathrm{ft}^{3}\right)\end{array}$ \\
\hline
\end{tabular}

NOTE TO USGS USERS: Use of hectare (ha) as an alternative name for square hectometer $\left(\mathrm{hm}^{2}\right)$ is restricted to the measurement of small land or water areas. Use of liter (L) as a special name for cubic decimeter $\left(\mathrm{dm}^{3}\right)$ is restricted to the measurement of liquids and gases. No prefix other than milli should be used with liter. Metric ton ( $\mathrm{t}$ ) as a name for megagram (Mg) should be restricted to commercial usage, and no prefixes should be used with it. 


\section{Abbreviations Used in This Report}

$\begin{array}{ll}\mathrm{Bq} / \mathrm{m}^{3} & \text { becquerel per cubic meter } \\ \mathrm{g} / \mathrm{cm}^{3} & \text { gram per cubic centimeter } \\ \mathrm{ha} & \text { hectare } \\ \mathrm{km} & \text { kilometer } \\ \mathrm{km}^{2} & \text { square kilometer } \\ \mathrm{m} & \text { meter } \\ \mathrm{m}^{3} & \text { cubic meter } \\ \mu \mathrm{m} & \text { micrometer } \\ \mathrm{Ma} & \text { mega-annum } \\ \mathrm{mm} & \text { millimeter } \\ \mathrm{Mt} & \text { megatonne } \\ \mathrm{nT} & \text { nanotesla } \\ \mathrm{t} & \text { tonne (metric ton; 1,000 kilograms) } \\ & \\ \mathrm{IP} & \text { induced polarity } \\ \mathrm{MIR} & \text { mid-infrared spectrum } \\ \mathrm{NIR} & \text { near-infrared spectrum } \\ \mathrm{REE} & \text { rare earth element } \\ \text { US\$ } & \text { U.S. dollar } \\ \mathrm{VIS} & \text { visible spectrum }\end{array}$




\title{
Deposit Model for Heavy-Mineral Sands in Coastal Environments
}

\author{
By Bradley S. Van Gosen, David L. Fey, Anjana K. Shah, Philip L. Verplanck, and Todd M. Hoefen
}

\section{Abstract}

This report provides a descriptive model of heavy-mineral sands, which are sedimentary deposits of dense minerals that accumulate with sand, silt, and clay in coastal environments, locally forming economic concentrations of the heavy minerals. This deposit type is the main source of titanium feedstock for the titanium dioxide $\left(\mathrm{TiO}_{2}\right)$ pigments industry, through recovery of the minerals ilmenite $\left(\mathrm{Fe}^{2+} \mathrm{TiO}_{3}\right)$, rutile $\left(\mathrm{TiO}_{2}\right)$, and leucoxene (an alteration product of ilmenite). Heavy-mineral sands are also the principal source of zircon $\left(\mathrm{ZrSiO}_{4}\right)$ and its zirconium oxide; zircon is often recovered as a coproduct. Other heavy minerals produced as coproducts from some deposits are sillimanite/kyanite, staurolite, monazite, and garnet. Monazite $\left[(\mathrm{Ce}, \mathrm{La}, \mathrm{Nd}, \mathrm{Th}) \mathrm{PO}_{4}\right]$ is a source of rare earth elements as well as thorium, which is used in thorium-based nuclear power under development in India and elsewhere.

The processes that form coastal deposits of heavy-mineral sands begin inland. High-grade metamorphic and igneous rocks that contain heavy minerals weather and erode, contributing detritus composed of sand, silt, clay, and heavy minerals to fluvial systems. Streams and rivers carry the detritus to the coast, where they are deposited in a variety of coastal environments, such as deltas, the beach face (foreshore), the nearshore, barrier islands or dunes, and tidal lagoons, as well as the channels and floodplains of streams and rivers in the coastal plain. The sediments are reworked by waves, tides, longshore currents, and wind, which are effective mechanisms for sorting the mineral grains on the basis of differences in their size and density. The finest-grained, most dense heavy minerals are the most effectively sorted. The result is that heavy minerals accumulate together, forming laminated or lens-shaped, heavymineral-rich sedimentary packages that can be several meters and even as much as tens of meters thick. Most economic deposits of heavy-mineral sands are Paleogene, Neogene, and Quaternary in age; some are modern coastal deposits.

Superimposed on these basic processes of ore formation are a multitude of contributing and modifying factors, such as the following:

- Strong, sustained wave action moves sand from offshore to the shore, where the sand and heavy minerals are sorted by size and density. Mineral sorting occurs mainly on the upper part of the hightide swash (wave) zone.

- Fine-grained sands and heavy minerals on the foreshore can be remobilized by winds, forming heavy mineral-rich sand dunes behind the beach.

- Longshore drift combined with the geomorphology of the coast exert strong influence on the location of the heavy-mineral sands deposits.

- Sea level changes are a function of climatic changes, such as ice ages. Rises in regional sea level (transgression) and lowering of sea level (regression) strongly influence the deposition and preservation of heavy-mineral sands. The majority of heavy-mineral sands accumulation appears related to seaward progradation of the shore during regression events.

- Local faulting may affect the geomorphology of the coast, which controls the distribution of heavy mineral deposition in a coastal basin.

- Heavy mineral grains appear to weather primarily after their deposition in the coastal plain; this weathering is caused by groundwaters, humic acids, and other intrabasinal fluids. This weathering can enhance the $\mathrm{TiO}_{2}$ content of ilmenite. Iron is leached from ilmenite during weathering, which thereby upgrades the $\mathrm{TiO}_{2}$ content of the ilmenite, forming leucoxene.

The resulting deposits of heavy-mineral sands can be voluminous. Individual bodies of heavy mineral-rich sands are typically about 1 kilometer wide and more than 5 kilometers long. Many heavy-mineral sands districts extend for more than 10 kilometers and contain several individual deposits that are spread along an ancient or modern strandline. Reported thicknesses of economic deposits range from 3 to 45 meters. Individual ore deposits typically comprise at least 10 megatonnes of ore (the total size of the individual sand-silt body), whose overall heavy-mineral content is 2 to greater than 10 percent.

Heavy-mineral sands deposits are relatively easy to mine because they are weakly to poorly consolidated, and they are relatively easy to process. From a geoenvironmental standpoint, mining of heavy mineral-sands generates little 
or no acid or solubilized metals. However, environmental and human health concerns related to such mining include potential effects on indigenous flora and fauna, effects on local hydrology, and issues related to processing and storing thorium-bearing monazite, owing to its radioactivity.

Regional exploration for deposits of heavy-mineral sands can utilize the analyses of stream sediment samples for Ti, Hf, the rare earth elements, Th, and $\mathrm{U}$, and geophysical surveys, particularly radiometric (gamma-ray spectrometry for $\mathrm{K}, \mathrm{U}$, and Th) and magnetic methods. Geophysical anomalies may be small, and surveys are generally more successful when conducted close to sources of interest.

\section{Introduction}

This report is a descriptive model for voluminous deposits of heavy minerals hosted by sediments of sand, silt, and clay deposited in coastal environments. These types of sedimentary deposits can contain economic concentrations of heavy minerals, in which the ore minerals (heavy minerals) are relatively easy to recover and then are used in a variety of industrial mineral applications. This deposit type is commonly referred to as "heavy-mineral sands."

Rivers and streams carry sediments to coastal areas, where the detritus are deposited, reworked by waves, tides, and wind, and thus concentrated in a variety of coastal depositional environments. Sedimentation can occur in deltas, the beach face (foreshore), sand dunes behind the shore, offshore, barrier islands, and tidal lagoons, as well as in the channels and floodplains of streams and rivers within a coastal plain. The sediments brought to the coast carry varying amounts of heavy, dense minerals, which can ultimately compose several percent of the resulting sedimentary deposit. The actions of waves, longshore currents, wind, and tides naturally sort and concentrate the heavy, dense minerals ("heavies") into layers (fig. 1).
These deposits have been, and continue to be, the principal global source of several important "heavy" industrial minerals, in particular titanium-bearing ore minerals (ilmenite, rutile, and leucoxene) and zircon. Other coexisting heavy minerals are often produced as coproducts, such as sillimanite/ kyanite, staurolite, monazite, and garnet (table 1). Dozens of coastal deposits are mined and processed to extract heavy minerals on every continent except Antarctica. Economic deposits typically contain heavy-mineral contents of at least 2 percent. For decades, these deposits have been referred to in the industrial minerals business and the scientific literature as heavy-mineral sands.

Economic deposits of heavy-mineral sands encompass modern and ancient examples. Heavy-mineral sands operations exploit deposits that range in age from Cretaceous to Holocene. They include Holocene (Recent) sediments on modern coasts as well as coastal deposits formed by transgressions and regressions of the seas during intervals in the Quaternary, Tertiary, and Cretaceous. Through an understanding of modern sedimentary systems, we are able to readily interpret and understand the geology and form of the Cretaceous to Holocene deposits (fig. 2).

Many heavy-minerals sands deposits are currently worked by modern mining operations. Examples of these deposits are briefly described in this report, providing a perspective on the size, common characteristics, and production typical of commercial deposits.

\section{Overview of Mineral Resource Importance}

Deposits of heavy-mineral sands in coastal environments play a substantial role in the global mineral economy. As the most noteworthy example, heavy-mineral sands are the world's primary source of titanium feedstock for the titanium dioxide $\left(\mathrm{TiO}_{2}\right)$ pigments industry (Gambogi, 2012); the titanium is obtained from the minerals ilmenite $\left(\mathrm{Fe}^{2+} \mathrm{TiO}_{3}\right)$, rutile $\left(\mathrm{TiO}_{2}\right)$, and leucoxene (an alteration product of ilmenite).

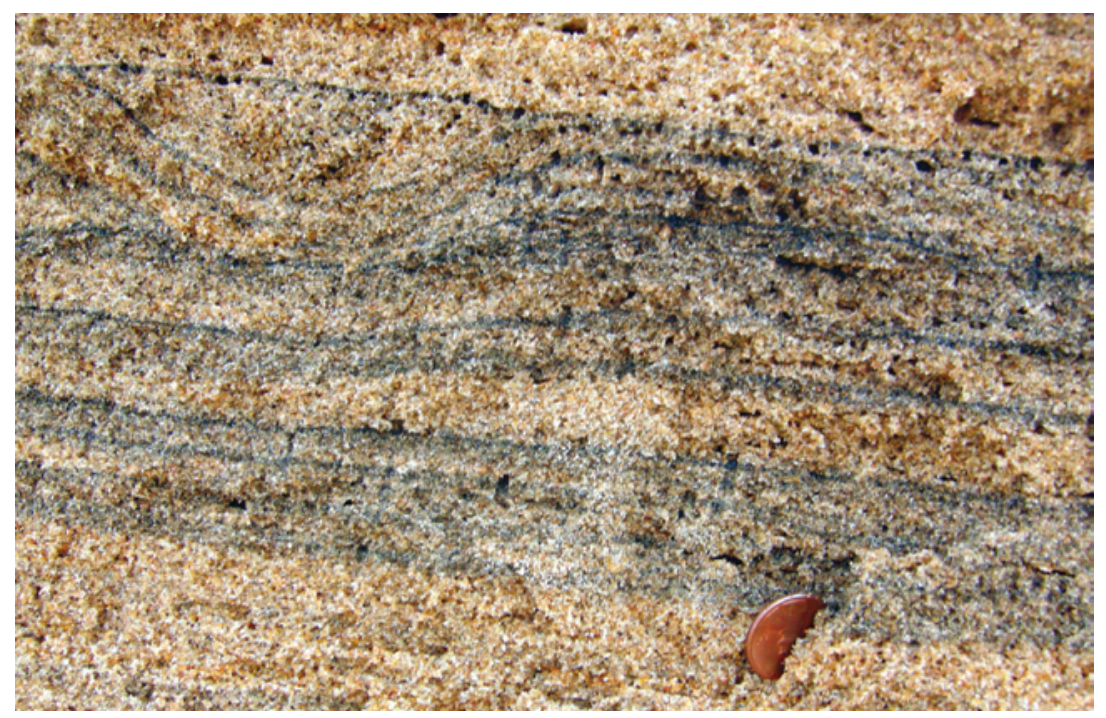

Figure 1. Heavy-mineral layers ("black sand") in quartz beach sand, Chennai, Tamil Nadu state, India. Photograph by Mark A. Wilson, Department of Geology, The College of Wooster, Wooster, Ohio, and used with permission. Penny for scale. 
Table 1. Common minerals in heavy-mineral sands deposits.

[Listed in order of average specific gravity — highest density to lowest - not by abundance. Leucoxene is an informal name for altered ilmenite, not an officially recognized mineral. In nature, the specific gravity of a mineral varies from the mineral's pure form owing to impurities and alteration. "Heavy minerals" are generally defined as dense minerals that have a specific gravity greater than 2.85]

\begin{tabular}{|c|c|c|}
\hline Specific gravity & Mineral & Ideal composition \\
\hline & Heavy mineral & \\
\hline 5.3 & Hematite & $\mathrm{Fe}_{2} \mathrm{O}_{3}$ \\
\hline 5.2 & Magnetite & $\mathrm{Fe}_{3} \mathrm{O}_{4}$ \\
\hline 5.0 & Pyrite & $\mathrm{FeS}_{2}$ \\
\hline 4.8 & Pyrolusite & $\mathrm{MnO}_{2}$ \\
\hline $4.6-5.4$ & Monazite & $(\mathrm{Ce}, \mathrm{La}, \mathrm{Y}, \mathrm{Th}) \mathrm{PO}_{4}$ \\
\hline 4.7 & Ilmenite & $\mathrm{FeTiO}_{3}$ \\
\hline 4.7 & Zircon & $(\mathrm{Zr}, \mathrm{Hf}, \mathrm{U}) \mathrm{SiO}_{4}$ \\
\hline $4.4-5.1$ & Xenotime & $\mathrm{YPO}_{4}$ \\
\hline 4.4 & Goethite & $\alpha \mathrm{FeO} \cdot \mathrm{OH}$ \\
\hline $4.2-4.3$ & Rutile & $\mathrm{TiO}_{2}$ \\
\hline 4.0 & Corundum & $\mathrm{Al}_{2} \mathrm{O}_{3}$ \\
\hline $3.8-4.2$ & Leucoxene & $\mathrm{FeTiO}_{3}$ to mostly $\mathrm{TiO}_{2}$ \\
\hline $3.7-3.8$ & Staurolite & $\mathrm{Fe}_{2} \mathrm{Al}_{9} \mathrm{O}_{6}\left(\mathrm{SiO}_{4}\right)_{4}(\mathrm{O}, \mathrm{OH})_{2}$ \\
\hline $3.6-4.0$ & Limonite & $\mathrm{FeO} \cdot \mathrm{OH} \cdot n \mathrm{H}_{2} \mathrm{O}$ \\
\hline $3.5-4.1$ & Spinel & $\mathrm{MgAl}_{2} \mathrm{O}_{4}$ \\
\hline $3.4-3.6$ & Sphene & $\mathrm{CaTiO}\left(\mathrm{SiO}_{4}\right)$ \\
\hline $3.4-3.5$ & Epidote & $\mathrm{Ca}_{2}(\mathrm{Al}, \mathrm{Fe}) \mathrm{Al}_{2} \mathrm{O}\left(\mathrm{SiO}_{4}\right)\left(\mathrm{Si}_{2} \mathrm{O}_{7}\right)(\mathrm{OH})$ \\
\hline $3.1-4.3$ & Garnets & $(\mathrm{Mg}, \mathrm{Fe}, \mathrm{Mn}, \mathrm{Ca}) \mathrm{Al}_{2} \mathrm{Si}_{3} \mathrm{O}_{12}$ \\
\hline $3.6-3.7$ & Kyanite & $\mathrm{Al}_{2} \mathrm{SiO}_{5}$ \\
\hline 3.2 & Sillimanite & $\mathrm{Al}_{2} \mathrm{SiO}_{5}$ \\
\hline 3.2 & Andalusite & $\mathrm{Al}_{2} \mathrm{SiO}_{5}$ \\
\hline $3.0-3.3$ & Tourmaline & $(\mathrm{Na}, \mathrm{Ca})(\mathrm{Li}, \mathrm{Mg}, \mathrm{Al})(\mathrm{Al}, \mathrm{Fe}, \mathrm{Mn})_{6}\left(\mathrm{BO}_{3}\right)_{3}\left(\mathrm{Si}_{6} \mathrm{O}_{18}\right)(\mathrm{OH})_{4}$ \\
\hline \multirow[t]{2}{*}{$2.85-3.6$} & Amphibole & $\mathrm{W}_{0-1} \mathrm{X}_{2} \mathrm{Y}_{5} \mathrm{Z}_{8} \mathrm{O}_{22}(\mathrm{OH}, \mathrm{F})_{2}$ (general formula) \\
\hline & Light mineral & \\
\hline $2.8-3.2$ & Biotite & $\mathrm{K}(\mathrm{Mg}, \mathrm{Fe})_{3}\left(\mathrm{AlSi}_{3} \mathrm{O}_{10}\right)(\mathrm{OH})_{2}$ \\
\hline $2.8-2.9$ & Muscovite & $\mathrm{KAl}_{2}\left(\mathrm{AlSi}_{3} \mathrm{O}_{10}\right)(\mathrm{OH})_{2}$ \\
\hline 2.65 & Quartz & $\mathrm{SiO}_{2}$ \\
\hline 2.6 & Kaolinite & $\mathrm{Al}_{2} \mathrm{Si}_{2} \mathrm{O}_{5}(\mathrm{OH})_{4}$ \\
\hline $2.56-2.76$ & Feldspar & $(\mathrm{K}, \mathrm{Na}, \mathrm{Ca}) \mathrm{AlSi}_{3} \mathrm{O}_{8}$ \\
\hline
\end{tabular}



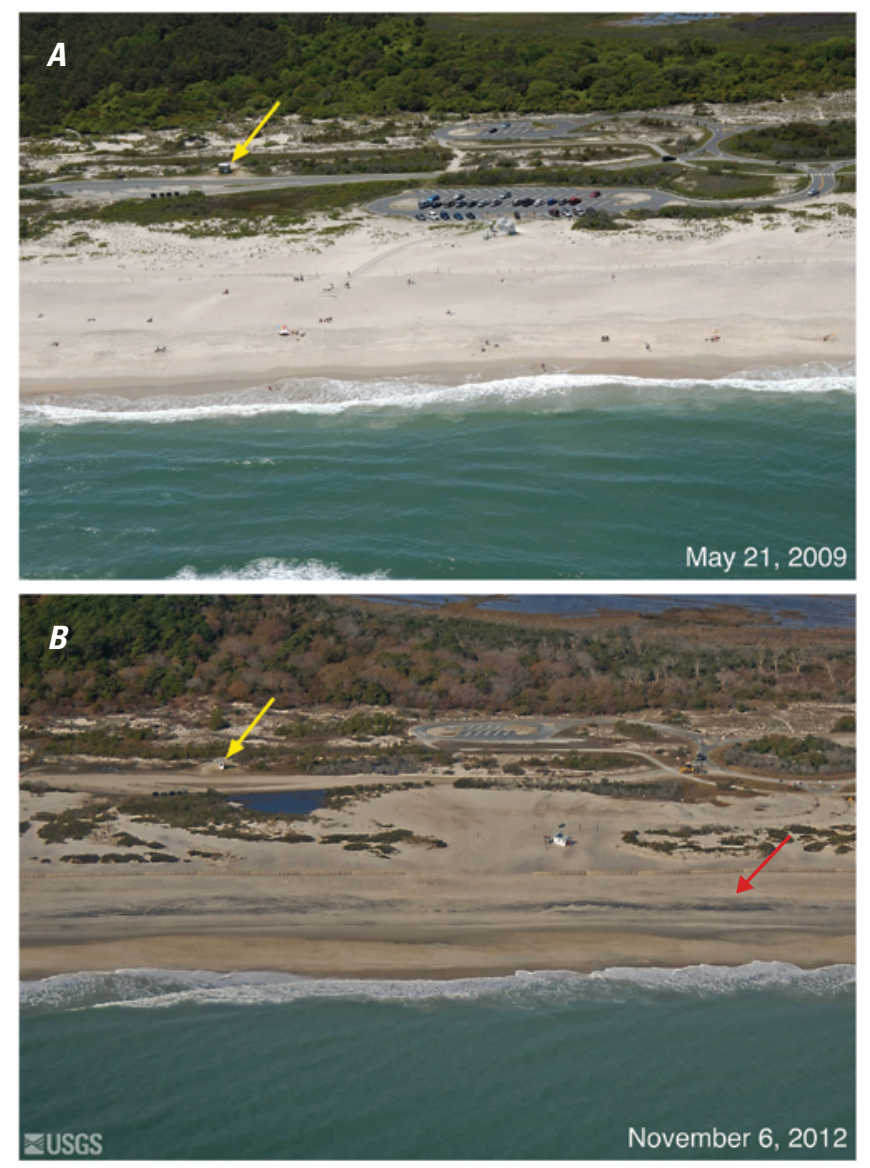

Figure 2. Two views of an area of Assateague Island, Maryland, photographed before and after Hurricane Sandy, which hit the region October 28-30, 2012. The storm surge moved sand over and through the low dunes at this location and deposited considerable sand in the parking lot. Yellow arrow $(A, B)$ points to same feature; red arrow $(B)$ points to dark concentrations of heavy minerals on the upper shoreface. Photographs courtesy of U.S. Geological Survey St. Petersburg Coastal and Marine Science Center (http://coastal.er.usgs.gov/ hurricanes/sandy/photo-comparisons/delaware-maryland.php).

Another source of titanium is anorthosite bodies, represented by two mines, one in Canada (Lac Tio in Quebec) and one in Norway (Tellnes) (Woodruff and others, 2013). In 2012, about 95 percent of the titanium mineral concentrates produced in the United States, predominantly from heavy-mineral sands, were used in the $\mathrm{TiO}_{2}$ pigment industry. Powdered titanium dioxide is bright white; it is the most widely used white pigment owing to its high brightness and very high refractive index. As a result, $\mathrm{TiO}_{2}$ in powder form is used extensively to provide even whiteness in paints and coatings, plastics and rubber, and paper (Gambogi, 2012; Bedinger, 2013). In 2011, world global titanium oxide pigment consumption was 5.33 megatonnes (Mt) and growing (Adams, 2012). In 2012, about 5 percent of domestic titanium mineral concentrates was used in welding rod coatings and the manufacture of carbides, chemicals, and metal. In 2012, the value of titanium mineral concentrates consumed in the United States was about United States dollars (US\$)735 million. Thus, titanium mineral concentrates, produced from deposits of heavy-mineral sands, represent a major industry in the United States as well as in many other nations.

Heavy-mineral sands are also the principal source of the mineral zircon $\left(\mathrm{ZrSiO}_{4}\right)$, obtained as a coproduct during the separation and recovery of the titanium minerals. Zirconium oxide offers high light reflectivity and thermal stability, and thus it is used mostly in refractory products as an opacifier for glazes on ceramics such as tiles, and by the foundry industry (Loferski, 2013a, b). Zircon and zirconium oxide are also used in abrasives, chemicals, metal alloys, and welding rod coatings.

In some heavy-mineral-sands deposits, the mineral monazite $\left[(\mathrm{Ce}, \mathrm{La}, \mathrm{Nd}, \mathrm{Th}) \mathrm{PO}_{4}\right]$ is a coproduct mineral recovered for its content of rare earth elements and thorium. In particular, India oversees a State-administered program designed specifically to recover monazite, along with other heavy minerals, derived from mining and processing multiple heavy-mineral sands deposits along India's southern coast (Malhotra, 2012; Indian Rare Earths Limited, 2013; Kerala Minerals \& Metals Limited, 2013). India has a particular interest in stockpiling monazite to later extract its thorium, a fuel needed for their nationalized effort to develop and operate thorium-based nuclear power plants (Martin, 2012).

Heavy-mineral sands deposits will continue to serve as a major source of titanium and a few other industrial minerals because these deposits have several advantages:

- Heavy-mineral sands deposits are usually voluminous and cover areas that can comprise hundreds of square kilometers. Individual heavy-mineral sands deposits typically comprise at the least $10 \mathrm{Mt}$ of ore (the total size of the individual sand-silt body) with heavy-mineral contents typically of 2 percent or greater. Combined resources within some districts, which typically represent a group of separate heavy-mineral sands deposits, have been estimated to exceed 1,000 Mt in total with an average heavymineral content exceeding 5 percent.

- These deposits are generally easy to excavate, which spares costs associated with blasting, rock crushing, and grinding. Most heavy-minerals sands deposits range in coherence from unconsolidated (modern beaches and dunes) to poorly consolidated; thus, these deposits are generally easy to excavate and work with heavy equipment.

- The mineral-separation techniques used in modern heavy-mineral processing plants are well established, highly mechanized, and efficient. Modern plants can 
control a continuous feed of high volumes of ore material (sand) that thereby maintains an effective pace of mineral separation, which can produce highpurity mineral products within hours.

- A single heavy-mineral sands deposit can supply several salable minerals as coproducts to the titanium minerals, such as zircon, staurolite, and monazite.

\section{Purpose and Scope}

This report is intended to provide an overview of the principal geological, mineral resource, and environmental characteristics of the deposit type that is commonly referred to as heavy-mineral sands. The report is part of an effort by the U.S. Geological Survey Mineral Resources Program to update existing mineral deposit models and develop new descriptive models as needed.

This descriptive model will focus on deposits of heavymineral sands formed in coastal plain settings. In general, coastal deposits of heavy minerals are considerably larger in volume and more continuous than their alluvial placer counterparts in stream and river deposits. The great majority of the largest heavy-mineral producers in the world are those that mine and process heavy-mineral sands deposits formed in a coastal environment, including examples of modern and ancient deposits.

\section{Deposit Type and Associated Commodities}

\section{Name}

Heavy-mineral sands in coastal environments

\section{Synonyms}

\section{Placers}

Placer deposits

Placer heavy minerals deposits

Beach placers

Black sand deposits

Mineral sands

Shoreline-related sands (Force, 1991)

Much of the terminology used to describe heavy-mineral sands is not formally used in the geologic literature. Thus, to aid the reader, below are some terms often used in discussions of this deposit type (fig. 3); these terms are likewise used descriptively in this report
- "Heavies" - informal term for heavy minerals.

- Heavy minerals - dense minerals that have a specific gravity greater than 2.85 . For comparison, quartz has a specific gravity of approximately 2.65 .

- Heavy mineral suite - entire group of heavy minerals identified within a particular deposit.

- Grade - with respect to a heavy-mineral-sands deposit, most often refers to average heavy-mineral content, typically reported in weight percent.

- Backshore - the berm that forms at the upper limit of wave action at high tide.

- Foreshore - the lower beach zone that is covered and uncovered by the sea from high tide to low tide. Sometimes also called the beach face or simply "the shore" or "the beach."

- Shoreface - the sloping zone that is permanently covered by water, seaward of the beach or foreshore. In this zone, beach sands are continuously reworked by waves.

- Strandline or shoreline - the level at which a standing body of water meets the land. In the context of this deposit type, the strandline is the beach area that lies above the sea or ocean.

\section{Brief Description}

Heavy-mineral sands are formed by the physical-mechanical concentration of bedrock minerals freed by weathering. The process begins inland of the coast where igneous, metamorphic, and sedimentary rocks erode and contribute detritus of sand, silt, clay, and heavy minerals to stream drainages. Streams and rivers carry the sediments to a coastal area, where they are deposited and redistributed in a variety of environments, such as deltas (Frihy, 1994), the beach face (foreshore), the shoreface, barrier islands, dunes, and tidal lagoons. Along the coast, the actions of waves, tides, and wind mechanically sort the mineral grains, naturally segregating heavy, high density minerals from lower density minerals. These sorting processes can form discrete thin layers and composite intervals in the sediments composed of dominantly heavy minerals (fig. 1). Studies indicate that the most significant sites of heavy-mineral accumulation are where the sediments are deposited in aeolian sand dunes, and the foreshore, shoreface, and lagoonal environments (fig. 3) (Force, 1991).

The economic heavy minerals in coastal deposits are particularly durable and resistant to chemical breakdown, and thus they survive the turbulent journey from the bedrock source area to the coast. The suite of heavy minerals most 


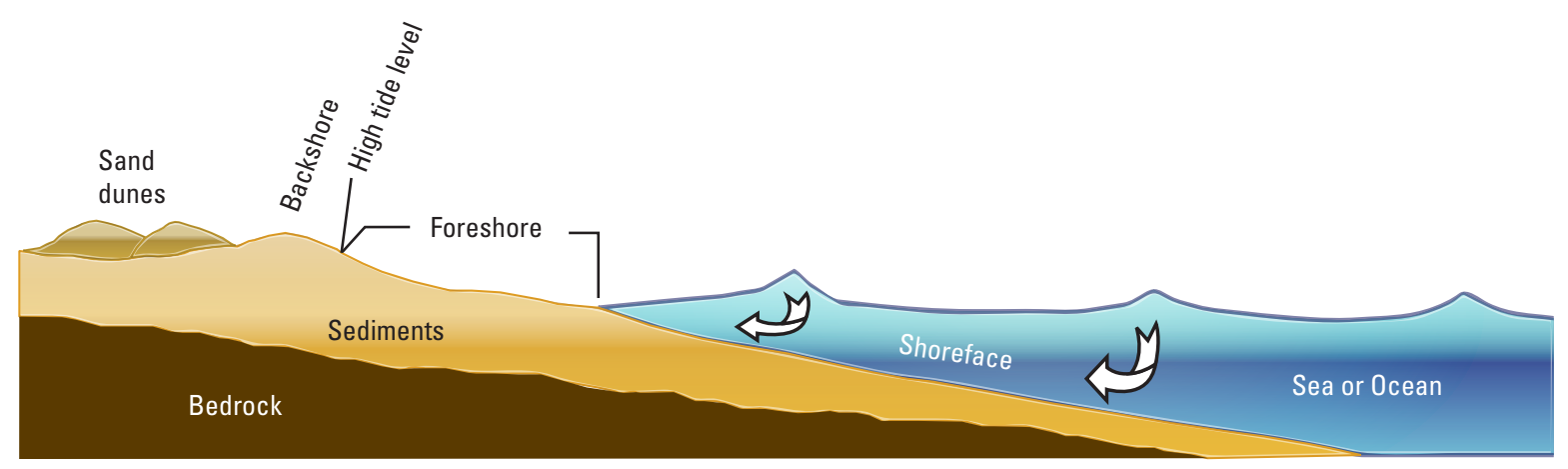

Figure 3. Features commonly used to describe shoreline (strandline) depositional environments associated with deposits of heavy-mineral sands. Not to scale.

commonly includes titanium-bearing minerals (ilmenite, rutile, and leucoxene) and zircon, and can also contain sillimanite/ kyanite, staurolite, monazite, and garnet (table 1). In the vast majority of heavy-mineral sands, ilmenite is the most abundant heavy mineral and the principal ore mineral, followed by rutile, leucoxene (altered ilmenite), and zircon. Together, ilmenite, rutile, and zircon often compose more than 80 percent of the heavy mineral suite. Other heavy minerals that are sometimes recovered as economic coproducts include garnets, sillimanite, staurolite, and monazite. Some economic deposits can contain less than 1 percent heavy-mineral content, but composite grades are typically more than 2 percent and locally can exceed 10 percent.

The light minerals (gangue) in heavy-minerals sands are dominated by quartz sand, clay minerals, and silt-size quartz and iron-hydroxide minerals. Feldspars are typically minor or absent, and carbonate minerals are rare.

Estimated (inferred) mineral resources within heavymineral sands deposits are highly variable, but tonnages are extremely large in comparison to most other ore types. Estimates of heavy-minerals sands resources that lump many deposits within a single district can exceed more than $1,000 \mathrm{Mt}$ of ore (total sand bodies). The heavy mineral-rich sand deposits that form a district can be vast in size, ranging from several kilometers to as much as tens of kilometers in length, such as the 100-kilometer $(\mathrm{km})$-long sand dunes complex that forms the Grande Côte deposit (Mineral Deposits Limited, 2013) along the west coast of Senegal, and a 72-km-long stretch of heavy-minerals sands along the northeastern shore of Sri Lanka (Lanka Minerals Sands Limited, 2013). Economic deposits of heavy-mineral sands range in thickness from about 3 to 45 meters (m) with widths of 0.4 to $4 \mathrm{~km}$.

Roy (1999) suggests that mature development of a heavy mineral suite is enhanced by (1) relatively low rates of sediment supply, (2) long periods of erosion, (3) strong sustained wave action that moves fluxes of sand onshore and along the shore, and (4) fluctuations in sea levels, particularly sea transgressions. He suggests these combined processes effectively move up to the shoreface heavy minerals previously deposited on the shelf. Important mechanisms for sorting and concentrating heavy minerals in the shore environment are interpreted to be (1) surf wave action in the swash zone of a beach, (2) high energy surf and surge driven by turbulence during storm events (fig. 2), and (3) long-shore drift (Baxter, 1977; Force, 1991). The forces of waves, tides, and longshore drift work the detritus, selectively carrying off lighter grains and leaving a fine-grained accumulation of heavy, dense mineral grains. Variations in particle settling velocities due to differences in mineral densities (table 1) work in concert with wave and tide actions in the swash zone to effectively segregate heavies from lights. The resulting sands are typically well sorted, medium- to fine-grained, well-rounded, and not indurated (Force, 1991).

Specific processes of heavy mineral enrichment, particularly on the beach face, are discussed by Force (1991). The principal zone of mineral separation is the upper part of the beach face, also known as the swash zone (the foreshore). The heaviest grains, which have the highest settling velocities, are deposited at the bottom of the swash zone. Coarse low-density detritus is carried by backwash to the wave zone, whereas heavy minerals tend to settle out and accumulate on the upper beach face (Komar and Wang, 1984). Thus, Force (1991, p. 75) describes heavy-mineral concentration as "a process involving lag enrichment on the swash face," in which erosion dominates deposition and "backwash efficiently sorts the available material, to produce a layer enriched in fine dense minerals." Economic deposits of heavy-mineral sands represent innumerable thin layers of heavy mineral accumulations separated by very small unconformities.

After sands accumulate on the beach, particularly in the backshore, winds can rework these sands and form sand dunes. Some of these aeolian deposits can contain substantial concentrations of heavy minerals. Wind can be a very effective mechanism for sorting the heavy, dense minerals from the lighter grains of sand. Aeolian processes created many of the world's largest fossil and recent heavy-mineral deposits, such as 
1. Brazil - the Quaternary Guaju deposits on the easternmost coastal area of Brazil (Sabedot and Sampaio, 2006), which are coastal dunes rich in ilmenite;

2. Brazil - deposits mined near Bujuru on the southern coast of Brazil, which are late Holocene backshore dune deposits (Dillenburg and others, 2004);

3. Senegal - the extensive Grande Côte heavy-mineral sands deposit (Mineral Deposits Limited, 2013), which is a Holocene mobile dune field extending about $100 \mathrm{~km}$ along the Senegal coast;

4. South Bay - the Richards Bay area deposits (Richards Bay Minerals, 2013) on the eastern coast of South Africa, where zircon, rutile, and ilmenite are recovered from a Quaternary stacked dune; and

5. Florida - the Trail Ridge deposits in north-central Florida, formed by a Pliocene dune field (Force and Rich, 1989).

Variations in coastal heavy-mineral sands deposits exist owing to many factors, but some common features characterize fossil and modern examples. Force (1991) notes that strandline deposits of Quaternary age share three basic characteristics: the deposits lie on passive margins of continents, the heavy minerals originate primarily in high-grade metamorphic terranes, and these deposits occur at latitudes less than $35^{\circ}$. These sand body complexes are generally oriented parallel to the coast and the paleostrandlines, corresponding to past fluctuations in local sea level. Many modern coastal plains and shores provide analogs to fossil heavy-mineral sands deposits. Modern examples are typically coastlines along passive margins that experience turbulent-swell wave action, are cut by rivers and streams that supply sediments from inland metamorphic and (or) crystalline rocks, and lie at middle to low latitudes $\left(35^{\circ} \mathrm{N}\right.$. to $35^{\circ} \mathrm{S}$.). The southwestern and southeastern coasts of India meet these criteria (Ali and others, 2001).

\section{Associated Deposit Types}

Fluvial deposits of heavy minerals are spatially and genetically associated with coastal deposits of heavy-mineral sands. Fluvial systems transport the sediments that carry heavy minerals from the source area to the coastal plain and shore. Where the alluvial sediments are deposited before they reach the coastal plain, they are another potential source of heavy mineral deposits. Alluvial deposits containing economic or potentially economic concentrations of heavy minerals are traditionally referred to as "placer deposits" or simply "placers."

Force (1991) noted that many nonmarine placer deposits of titanium oxide minerals are known. However, thus far (2013) only one such deposit, a rutile-rich fluvial placer in Sierra Leone, has been of economic significance. Force (1991, p. 65-66) explained that the paucity of economic placer deposits of titanium relative to shoreline placers is primarily due to the small scale of the fluvial placers and the enhanced favorability for shoreline placer deposits to undergo extensive ilmenite alteration, thereby increasing the titanium content. Regarding the first point, fluvial deposits are typically poorly sorted, and thus they offer little preconcentration of the heavies.

Gold placers within fluvial drainages are the most well recognized examples of economic heavy-mineral placers worldwide. Numerous examples of gold placer deposits exist and are well documented. In contrast, gold rarely occurs in economic concentrations in coastal heavy-mineral sands. The very high density of gold (specific gravity of 15-19.3), particularly relative to the other heavies, means that gold is commonly deposited inland within a fluvial placer environment before it reaches the coastal plain.

Tin placers, which are fluvial deposits rich in cassiterite $\left(\mathrm{SnO}_{2}\right)$, can be regionally associated with but occur upstream from coastal heavy-mineral sands. These cassiterite-rich alluvial deposits are inland of the coast, but the host streams and rivers move bedload carrying heavy minerals farther downstream and ultimately reach the coastal plain. Examples occur in Malaysia. Prior to the domination of global yttrium production by China in the late 1980s (Tse, 2011), xenotimebearing alluvial tin placer deposits in Malaysia were the largest sources of yttrium in the world (Castor and Hedrick, 2006). Malaysia's tin placer deposits carry considerable cassiterite, which is accompanied by ilmenite, monazite, and xenotime. Recently, tailings produced from past tin placer mining have been reprocessed to recover monazite and xenotime. In this manner, 350 tonnes $(t)$ of rare-earth oxides were produced from Malaysia in 2012 (Gambogi, 2013).

Monazite-bearing alluvial placers are well known, and some in the southeastern United States produced monazite as a coproduct or byproduct commodity in the past. In fact, prior to the mid-1960s when full-scale mining and production began from the Mountain Pass carbonatite deposit, California, alluvial placers were the primary source of rare earth elements for the United States. A century ago, monazite was produced from alluvial placers in mountain valleys of North Carolina and South Carolina. The monazite found in stream placers of this region is thought to have the same source - high-grade metamorphic rocks of the Piedmont region - as the monazite found in the coastal heavy-mineral sands of the southeastern United States.

In 1887, a few tons of monazite were produced from stream deposits in the Piedmont region of North and South Carolina, giving this region the distinction of being the world's first supplier of thorium (Olson and Overstreet, 1964). Monazite-bearing placers of this region were worked by smallscale sluice operations from 1887 to 1911 and 1915 to 1917, producing a total of about 5,000 t of monazite (Overstreet and others, 1968). Monazite mining ended here in 1917, not because reserves had been exhausted, but rather because the beach deposits of India and Brazil were producing thorium at lower cost. 
The high-grade monazite placers of the Piedmont of North Carolina and South Carolina lie between the Catawba River in the northeast and the Savannah River in the southwest, along a belt that extends from east-central Virginia southwestward into Alabama (Mertie, 1975). Concentrations of the heavy minerals are greatest in the headwaters areas. Stacked layers of unconsolidated gravel, sand, clay, and clayey silt average about $4.5 \mathrm{~m}$ thickness in these areas (Staatz and others, 1979). Monazite typically occurs in all units but is generally most abundant in the basal gravel layers and least abundant in the clay layers. Dredging in this region between the summers of 1955 and 1958 (Williams, 1967) indicated heavy-mineral contents of about 1 to 1.5 percent; monazite formed about 8 percent of the heavies (Mertie, 1975). Dredging operations recovered monazite, ilmenite, rutile, zircon, and staurolite (Williams, 1967).

The heavy-mineral content of the placer deposits of the Piedmont region ranges from 0.15 to 2.0 percent, and monazite forms about 3.5-13 percent of the heavy minerals (Staatz and others, 1979). Other parts of the heavy-mineral fraction include 20-70 percent ilmenite, 2-50 percent garnet, $0.3-7$ percent rutile, trace to 14 percent zircon, and trace to 20 percent combined sillimanite and kyanite. Additional heavy minerals include epidote, magnetite, xenotime, tourmaline, sphene, staurolite, andalusite, and an unidentified black radioactive mineral (Staatz and others, 1979). Analysis of 52 samples of alluvial monazite from this region (Mertie, 1975) found that the monazite contains 60-63 percent total rare earth element (REE) oxides and 2.5-7.8 percent thorium oxide.

In southwestern Sri Lanka, monazite-bearing stream sediments of the Bentota River have been described as "one of the world's most thorium-rich sediments" (Rupasinghe and others, 1983, p. 1). Monazite is brought by this river system to the coast near Kaikawala and Beruwala, thereby forming monazite-rich seasonal beach sand deposits at these areas.

In addition to heavy minerals, the diverse depositional environments within coastal plains can host a variety of sedimentary industrial mineral deposits. For example, alluvium can be exploited for industrial sand and gravel. Coastal plains can contain deposits of peat, salt, sea shell accumulations (a source of calcium carbonate), or sulfur; these deposit types are in some places mined by artisanal methods.

\section{Primary Commodities}

The principal economic minerals in the majority of heavy-mineral sands operations are the titanium minerals, mainly ilmenite, rutile, and leucoxene, as well as zircon. As noted above, heavy-mineral sands are a primary source of titanium raw feedstock for the $\mathrm{TiO}_{2}$ pigments industry (Gambogi, 2012). Heavy-minerals sands are also the principal source of zirconium. In most coastal deposits, ilmenite is the most abundant of the heavy minerals.

Not all heavy-mineral sands are ilmenite dominant. In some locations, deposits contain more zircon than ilmenite, such as at the Jacinth and Ambrosia deposits in the Eucla basin of South Australia (Hou and others, 2011; Reid and others, 2013) and at several deposits in the Murray basin in Victoria and New South Wales, Australia (Geoscience Australia, 2012). In southwestern Sierra Leone, heavy-mineral sands near Mokaba are stated to be the world's largest primary rutile resource; these sands contain 1.48 percent rutile, 0.74 percent ilmenite, and 0.31 percent zircon (Sierra Rutile Limited, 2013).

In general, the primary commodities produced from heavy-mineral sands are ilmenite, rutile, and leucoxene, and commonly zircon. Ilmenite is usually the most abundant mineral in the heavy mineral suite, and ilmenite is overall the highest quantity of mineral product recovered and sold from heavy-mineral sands. Other heavy minerals (table 1), if retrieved and sold, are regarded as a coproduct.

\section{Byproduct Commodities}

Byproduct (coproduct) mineral production varies among differing heavy-mineral deposits and their particular mining and processing operations. Sillimanite, staurolite, garnet, monazite, and xenotime (table 1) are minerals reportedly recovered from various heavy-mineral sands and sold as coproducts of titanium and zirconium production. Orris and Grauch (2002) list 264 shoreline placers with enrichments in rare earth elements; these rare earths occur primarily in monazite and less consistently in xenotime.

Byproduct monazite has been recovered from historical placer deposits in Australia, Brazil, China, Indonesia, Korea, Malaysia, New Zealand, Sri Lanka, Thailand, Zaire, and the United States. Recently, monazite has been recovered from beach and alluvial placers in India, Malaysia, Sri Lanka, Thailand, and Brazil. Indian beach placers are the principal present-day source for the production of monazite (described in Example Deposits).

\section{Trace Constituents}

Other constituents of the heavy mineral suite can include cassiterite, kyanite, corundum, and tourmaline (table 1). According to recent company reports, none of these minerals is currently recovered in the processing of a deposit and thereby valued as a coproduct.

\section{Example Deposits}

Heavy-mineral sands deposits are found on every continent, with the possible exception of Antarctica. The examples that follow should not be regarded as a complete list of all known deposits of this type throughout the world. Rather, these are examples of deposits of heavy-mineral sands that have been worked in the past or are being mined today (or both); thus, they typify economic deposits of heavymineral sands. 
Detailed descriptions of individual heavy-mineral sands deposits are generally lacking in the literature for much of the world. Information on grade and tonnage for deposits are relatively easy to obtain through company Web sites owing to resource disclosure requirements, particularly for deposits in development or those under consideration for development. However, detailed geologic descriptions of heavy-mineral sands deposits are generally sparse in the geologic literature or in company Web sites.

\section{Australia}

The vast majority of the heavy-mineral resources of Australia are hosted by ancient beach and sand dune deposits that formed along middle Eocene to Pleistocene strandlines (Hoatson and others, 2011). Extensive fossil beach deposits of heavy minerals occur in three inland Cenozoic-age sedimentary basins (the Perth, Murray, and Eucla basins) of western and southern Australia (fig. 4). The Perth basin lies in the southwestern part of Western Australia, comprising the Eneabba and Cooljarloo strandline deposits north of Perth (Figure 4, locations 7 and 9) and the Yoganup and Happy Valley strandline deposits south of Perth (fig. 4, locations 8 and 10). Heavy-mineral beach deposits of the Murray basin developed in Cenozoic paleostrandlines in New South Wales, Victoria, and South Australia. The Eucla basin bounds the coast of the southwestern part of South Australia.

Eucla Basin, South Australia. Since 2009, Iluka Resources has been mining and processing mineral sands of the Jacinth-Ambrosia deposits (fig. 4), located about $270 \mathrm{~km}$ northwest of Ceduna, South Australia. The property consists of two contiguous heavy-mineral deposits - Jacinth and Ambrosia. Iluka Resources (2013a; see also "Eucla Basin, South Australia" link on the company website) reports: "Mining is continuing on the Jacinth deposit, which is approximately 900 metres wide by 5 kilometres in length. The ore body is between 20 metres and 45 metres thick and is covered by up to 8 metres of overburden." The company is evaluating several nearby deposits for potential development. The actively mined heavy-mineral sands of this area, the contiguous Jacinth and Ambrosia deposits, contain about 50 percent zircon in the heavy-mineral suite (Geoscience Australia, 2012); as a result, zircon is the main product from Iluka Resources' operations here. The Jacinth-Ambrosia operation has been the world's largest zircon recovery project for several decades. Rutile and ilmenite are also abundant and recovered for sale. In January of 2011, Iluka Resources reported that their recently discovered Atacama deposit (fig. 4), located northeast of the JacinthAmbrosia mine, contains 29.2 Mt of sands containing 11.3 percent heavy minerals; the heavy mineral suite is composed of 75 percent ilmenite and leucoxene, 15 percent zircon, and 2 percent rutile, with a heavy-mineral cut-off grade of 5 percent (Geoscience Australia, 2012).

Also in the Eucla basin, in the southeastern part of Western Australia near its border with South Australia, Image
Resources NL has drilled extensively into part of the Jacinth heavy-mineral sands deposit (Image Resources NL, 2013). In this same area, Diatreme Resources drilled their Cyclone, Cyclone Extended, and Monsoon deposits (fig. 4) (Image Resources NL, 2013). In 2010, Diatreme Resources Limited reported a measured, indicated, and inferred resource for the Cyclone deposit of $132.1 \mathrm{Mt}$ of sand grading 2.33 percent heavy minerals, which includes 980,000 t of zircon, 388,000 t of rutile, 551,000 t of high-Ti ilmenite and 382,000 t of altered ilmenite (Geoscience Australia, 2012).

Murray Basin, Victoria and New South Wales. The Murray basin (fig. 4) contains more than 100 Pliocene coastal sand deposits, which are estimated to hold, in total, heavy-mineral resources of more than $80 \mathrm{Mt}$ (Roy and Whitehouse, 2003). The high concentrations of heavy minerals found in strandline sands in the Murray basin were deposited during Pliocene seashore progradation events driven by sea level oscillations (Roy and others, 2000; Roy and Whitehouse, 2003). They suggest that the heavy minerals in the sand deposits were derived from storm and wave reworking of underlying heavy-mineralbearing Miocene sands, and that erosion and deposition were aided by growth faults.

In 2005, Bemax Resources Limited commenced the first heavy-mineral sands operation in the Murray basin with the Ginkgo mine (fig. 4). In 2010, the company opened the Snapper mine (fig. 4), about $10 \mathrm{~km}$ from the Ginkgo mine. For 2010, Bemax reported production from the combined Ginkgo and Snapper mines of 239,355 t of ilmenite, 32,564 t of zircon, and $84,863 \mathrm{t}$ of rutile (Geoscience Australia, 2012).

Since 2006, Iluka Resources has developed several heavy-mineral sands deposits within the Murray basin in Victoria, including reopening four former mines (Douglas, Bondi East, Echo, and Kulwin) and an active mining district (Woornack, Rownack, and Pirro mines) (fig. 4). The company also has two more proposed mine sites within the basin (Ikuka Resources, 2013a), both located in New South Wales. The longest deposit in the active mining district is approximately $14.5 \mathrm{~km}$ in length; individual deposits are as much as $130 \mathrm{~m}$ wide and 3-6 m thick (Iluka Resources, 2013a). During 2010, Iluka reported total production from their Murray basin operations of 198,400 $\mathrm{t}$ of rutile, 56,800 $\mathrm{t}$ of ilmenite, and 156,600 t of zircon (Geoscience Australia, 2012).

Exploration by Astron Limited led to their Donald Mineral Sands project in the south-central part of the Murray basin; their properties include the Donald and Jackson deposits (fig. 4). In December of 2011, the company reported total measured, indicated, and inferred resources for their combined deposits of 2,630 Mt grading 5.3 percent heavy minerals; the heavy mineral assemblage comprises 33 percent ilmenite, 19 percent zircon, 12 percent leucoxene, and 7 percent rutile (Astron Limited, 2013).

Also within the Murray basin, in western Victoria, the WIM150 mineral sands deposit (fig. 4) reportedly contains substantial resources of monazite and xenotime (O'Driscoll, 1988), associated with titanium minerals and zircon in its 


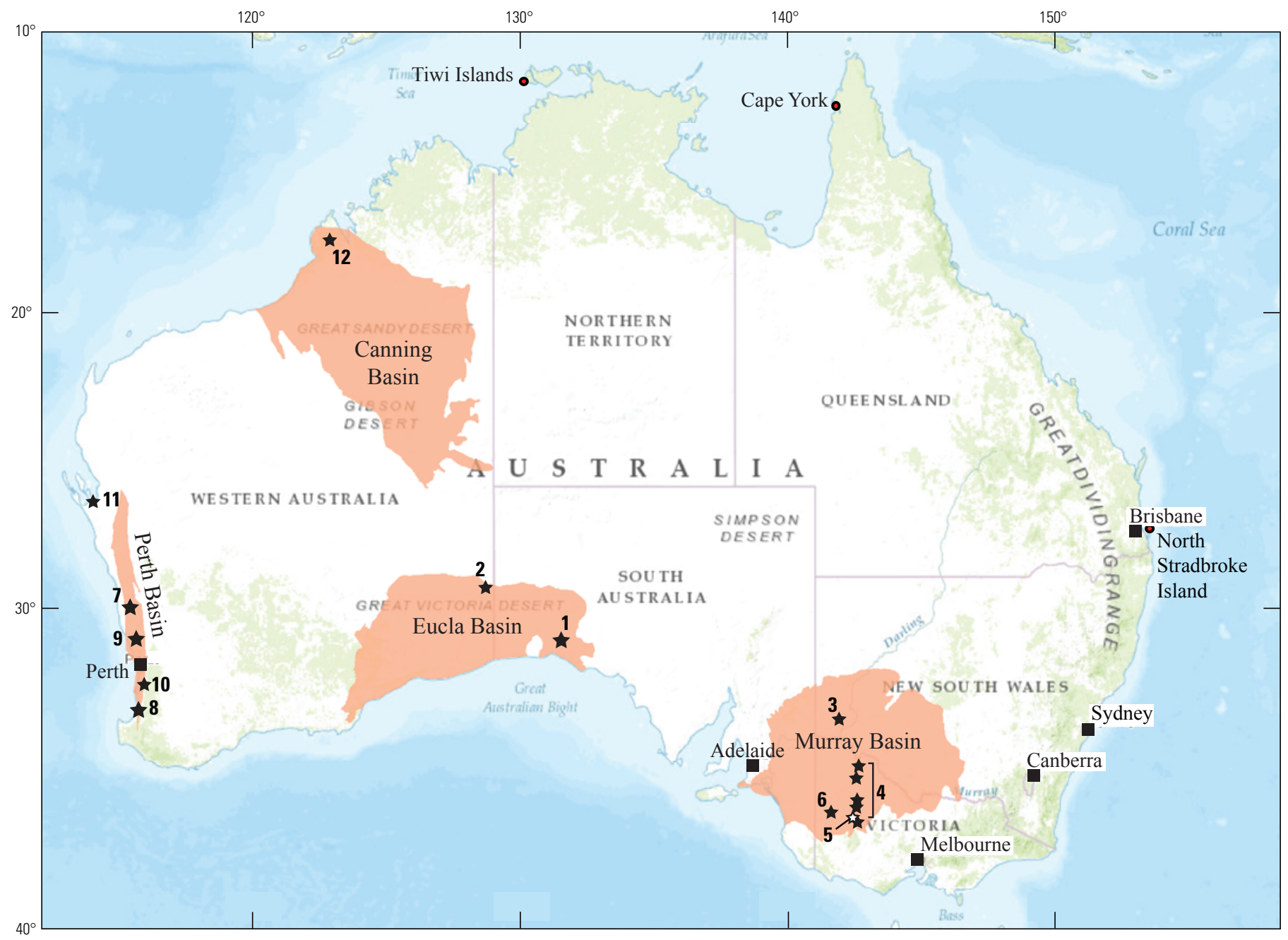

Figure 4. Australian Cenozoic sedimentary basins and other districts (Tiwi Islands, Cape York, North Stradbroke Island) hosting deposits of heavy-mineral sands that were being mined as of 2013. Numbered locations are active heavy-mineral-sands districts, mines, and projects in development discussed in this report.

1. Jacinth-Ambrosia deposits and Atacama deposit

2. Cyclone, Cyclone Extended, and Monsoon deposits

3. Ginkgo and Snapper mines

4. Elongate district with several mines, including (north to south): Kulwin, Woornack, Rownack, Pirro, Echo, Bondi East, Douglas

5. Donald and Jackson deposits

6. WIM150 deposit

7. Eneabba mining district

8. Tutunup South mine; Gwindinup and Happy Valley deposits

9. McCalls project; Boonanarring and Atlas deposits

10. MZI Resources Limited project

11. Gunson Resources Limited project

12. Dampier project 
heavy mineral suite. The deposit, which is about $14 \mathrm{~m}$ thick, comprises titanium- and zircon-rich sand bodies formed along a Tertiary strandline. The mineral sands project in 2013 was in an advanced stage of premining development and permitting (Australian Zircon NL, 2013), with plans to mine the sands for the titanium minerals and zircon. The deposit contains more than 580,000 $t$ of monazite and 170,000 $t$ of xenotime, although these minerals are unlikely to be exploited (O’Driscoll, 1988).

Perth Basin, Western Australia. Ancient beach and dune sands in the Cenozoic Perth basin of Western Australia (fig. 4) have been extensively mined for their heavy minerals since the late 1970s. The sands were deposited along strandlines during the Pliocene to early Pleistocene. The Eneabba mining district (fig. 4) in the northern part of the Perth basin has been a substantial producer of rutile and zircon. In recent years, Iluka Resources (2013a) has generated valuable zircon and ilmenite production by operating heavy-mineral mines and mineral separation plants both north and south of Perth. The Tutunup South mine of Iluka Resources, located on the southern end of the basin near Capel (fig. 4), began heavy-minerals production in June 2011. This mine produced ilmenite as its primary product, as well as zircon and rutile. In 2010, Iluka Resources reported a mining and processing output from their Perth basin operations of 41,500 t of rutile, 347,500 t of synthetic rutile, 255,800 t of ilmenite, and 46,200 t of zircon (Geoscience Australia, 2012). In February 2013, Iluka Resources (2013a) announced that its mining operations at Eneabba and Tutunup South would go on idle status owing to low demand.

The Eneabba mining district, in addition to its substantial production of rutile, zircon, and ilmenite, was also a former producer of coproduct monazite. Prior to 1995, about 2,500 t of monazite were recovered annually as a coproduct of titanium minerals and zircon processing in the Eneabba district (Castor and Hedrick, 2006; Hoatson and others, 2011). The source of the monazite in the ancient dune and beach sands is thought to be underlying Mesozoic sedimentary rocks, with Archean crystalline rocks of the basement being the original source (Shepherd, 1990). In the Eneabba deposits, monazite concentrations can be as much as 7 percent near the southern end of the barrier complex, deposited in the direction of the longshore drift near a relic headland (Shepherd, 1990). On average, heavy minerals compose about 6 percent of the paleoshore sands mined in this district; monazite composes 0.5 percent to 7.0 percent of this heavy mineral suite (Shepherd, 1990).

Sheffield Resources Limited has six ongoing advanced exploration projects in the Eneabba district. Their Yandanooka, Durack, Ellengail, and West Mine North deposits have reported measured, indicated, and inferred combined resources of $250 \mathrm{Mt}$ of sand grading 2.3 percent heavy minerals. The heavies comprise 66 percent ilmenite, 11.1 percent zircon, 5.5 percent rutile, and 4.4 percent leucoxene (Sheffield Resources Limited, 2013). About $110 \mathrm{~km}$ north of Perth near the town of Gingin, the McCalls project (fig. 4) contains an inferred resource of $4.4 \mathrm{Bt}$ of sands with 1.2 percent heavymineral content (Sheffield Resources Limited, 2013).
Bemax Resources Limited mines heavy-mineral sands in the southwestern part of Western Australia, at the Gwindinup and Happy Valley deposits (fig. 4), which contain a total of 2.9 Mt of heavy minerals, of which about 10 percent are zircon (Bemax Resources Limited, 2013). Ilmenite and leucoxene are also produced from these deposits (Geoscience Australia, 2012).

Since 1988, Tiwest Joint Venture has mined and processed heavy-mineral sands in the Eneabba district (fig. 4) near Cooljarloo, $14 \mathrm{~km}$ north of Cataby, Western Australia. Their mines include dredging and dry-mining operations. Reported production in 2010 was approximately $462,000 \mathrm{t}$ of ilmenite, 70,000 t of zircon, 36,000 t of rutile, and 26,000 t of leucoxene (Geoscience Australia, 2012).

In the northern part of the Perth basin, exploration and extensive drilling by Image Resources NL (2013) has identified numerous heavy-mineral sands deposits along subparallel, northwest-trending paleo-strandlines. Their combined Boonanarring and Atlas deposits, near Gingin (fig. 4), are about 7-km-long, as much as 400-m-wide, and contain a reported total resource of $32.3 \mathrm{Mt}$ of sand with 8.1 percent heavy minerals, which include zircon, rutile, leucoxene, and ilmenite (Image Resources NL, 2013).

MZI Resources Limited is developing a zirconleucoxene-rich mineral sands deposit at Keysbrook, located about $70 \mathrm{~km}$ southeast of Perth (fig. 4) (MZI Resources Limited, 2013). The sand deposit is aeolian and about 2-5 $\mathrm{m}$ deep, and it covers about $14 \mathrm{~km}^{2}$ (MZI Resources Limited, 2013).

On the basis of a drilling program conducted since 2000, Gunson Resources Limited has defined a substantial heavyminerals sand deposit near Coburn in western West Australia (fig. 4). The deposit is more than $35 \mathrm{~km}$ long, as much as $3 \mathrm{~km}$ wide, and 10-50 m thick (Gunson Resources Limited, 2013). Reported reserves are $308 \mathrm{Mt}$ averaging 1.2 percent heavy minerals. The heavy mineral suite comprises 23 percent zircon, 48 percent high titanium (61 percent $\mathrm{TiO}_{2}$ ) ilmenite, 7 percent rutile, and 5 percent leucoxene (Gunson Resources Limited, 2013).

Canning Basin, northeastern Western Australia. Sheffield Resources Limited operates their Dampier heavy-mineral sands project near Derby in the Canning basin (fig. 4), located inland of the coast of northern Western Australia. They report indicated and inferred resources in the Thunderbird deposit of the Dampier project of 1,374 Mt of sand with a heavy-mineral content of 6.1 percent; the heavy-mineral suite contains 29 percent ilmenite, 6.9 percent zircon, 4.3 percent leucoxene, and 1.6 percent rutile (Sheffield Resources Limited, 2013).

North Stradbroke Island, Queensland. Sibelco Australia has mined Quaternary deposits of heavy-mineral sands on North Stradbroke Island (fig. 4) since 1966 and dredged sediments offshore (Sibelco Australia, 2013). Their Pinkenba processing plant separates rutile, zircon, and ilmenite.

Cape York, Queensland. Oresome Australia Party Limited conducts ongoing exploration, permitting, and environmental assessment activities at their Cape York Minerals Sands project in northernmost Queensland (fig. 4). They report a resource of $2.8 \mathrm{Mt}$ of heavy-minerals sands containing 7 percent heavy 
minerals to a maximum depth of $3 \mathrm{~m}$ (Oresome Australia Pty. Limited, 2013).

Tiwi Islands, Northern Territory. MZI Resources Limited operated heavy-mineral sands mines and mineral processing from 2006 to early 2013 on Tiwi Islands (fig. 4), about $50 \mathrm{~km}$ north of Darwin in northern Australia. They extracted zircon, rutile, and leucoxene (MZI Resources Limited, 2013). Their Lethbridge West deposit on Melville Island was mined out in 2010 and the site is now remediated (2013). Their Lethbridge South mine, $4 \mathrm{~km}$ to the southeast, which operated from 2010 to January 2013, is now undergoing final cleanup. The company reports that their Lethbridge South deposit was four times as large as the Lethbridge West deposit but half the grade; the heavy-mineral content was 2.5 percent. Concentrate produced from Lethbridge South contained more than 30 percent zircon and 30 percent rutile (MZI Resources Limited, 2013). Currently, MZI Resources Limited is conducting drilling and a scoping study for their Kilimiraka deposit on the southwestern part of Barthurst Island within the Tiwi Islands.

\section{Brazil}

The monazite placers of the Brazilian coast include elevated paleobeaches, modern beaches, sand dunes, and the banks, channels, and bars of streams that deposit sediments near the shore. Cretaceous and Tertiary sandstones that formed along paleostrandlines crop out near the modern beach; some sandstone intervals are rich in monazite, ilmenite, and zircon. These sandstones are eroded and disaggregated by high-tide waves and storm surges. This erosional process redeposits sand and heavy minerals into the surf zone, where the heavy minerals are again reworked and sorted by waves, longshore drift, and tides. Thus, the Cretaceous-Tertiary strandline deposits, which formed in slightly higher outcrops near the modern beach, are another and often richer source of monazite. Leonardos (1974) indicated that the principal inland sources of detrital monazite along the central Brazilian coast are Archean amphibolite- to granulite-facies rocks, and the Cretaceous and Tertiary sedimentary rocks derived from erosion of the Archean rocks.

More than one dozen monazite-bearing placer districts have been developed intermittently along the central Brazilian coast (fig. 5) (Overstreet, 1967; Orris and Grauch, 2002). Past placer producers of monazite are found along the Brazilian coast between the city of Campos in the state of Rio de Janeiro to the south and southernmost Rio Grande do Norte state to the north end (fig. 5). Monazite was recovered as a coproduct of the mining of the more profitable titanium minerals (ilmenite, rutile) and zircon. In contrast to most heavy-mineral sands operations, many of the Brazilian deposits were mined primarily for their monazite, sought foremost as a source of thorium with titanium minerals and zircon treated as coproduct commodities. Overstreet (1967) stated that from 1900 to 1947 Brazil exported 56,350 t of monazite concentrate recovered from beach placers. Since the early 1990s, the Buena placer district (fig. 5), which includes the Buena Norte and Buena Sol deposits, has been the only active Brazilian producer of monazite; it participates in a state-administered program (Indústrias Nucleares do Brasil SA (INB), 2013).

The coastal sand deposits of Brazil have some of the highest monazite concentrations known in the world - as much as 8 percent average monazite in some sand bodies (Overstreet, 1967). The Guarapari coastline of Espiroto Santo (fig. 5) is a popular tourist destination known for its white sand beaches, but this shoreline is also known for its very high level of background radioactivity due to abundant monazite. The actively mined Buena Norte deposit has a reported monazite content of 0.83 percent (Jackson and Christiansen, 1993). Analyses of Brazilian monazites suggest that their average REE oxide content is typically 57-60 percent and that they are preferentially enriched in light REEs (Overstreet, 1967; Orris and Grauch, 2002).

Summarizing the monazite endowment in Brazil's coastal deposits state by state, Hedrick (1997) reported the following "measured reserves" of monazite, which more properly should have been stated as measured resources: 16,622 $\mathrm{t}$ grading 53.88 percent REE oxide in Bahia; 29,210 t grading 57 percent REE oxide in Ceara; 697,382 t grading 60 percent REE oxide in Espirito Santo; 326,766 t grading 59.72 percent REE oxide in Minas Gerais; and 17,166 t grading 60 percent REE oxide in the state of Rio De Janeiro. The proximity of many of these mineral-rich beach deposits to resorts and other population centers has been a major factor in restricting development of the monazite resources.

Millenium Chemical (formerly Millenium Inorganic Chemicals of Brazil) has operated the Guaju heavy-mineral sands mine on the easternmost coastal area of Brazil, near the city of Mataraca in the State of Paraiba, since 1983. The deposits are coastal dunes rich in ilmenite, the primary product of the mine; zircon, considered low quality owing to mineral inclusions, is recovered as a byproduct (Sabedot and Sampaio, 2006). Small amounts of monazite are reported in these deposits (Ferreira and others, 2007).

Near Bujuru on the southern coast of Brazil, heavy minerals are concentrated in backshore dune deposits that formed in the late Holocene. The heavy-mineral-rich zones in these deposits average about $3.5 \mathrm{~m}$ in thickness. Ore reserves have been estimated at $150.8 \mathrm{Mt}$ of sand with an average heavymineral content of 4.66 percent, of which about 60 percent is ilmenite (Dillenburg and others, 2004).

\section{China}

China has considerable resources of monazite within placer deposits; however, scant information on the characteristics and production of these resources has been published. Jackson and Christiansen (1993) reported that China produced 10,200 $\mathrm{t}$ of rare-earth oxides from placer deposits in 1989. Since that time, information about rare-earth production from placer deposits in China is unavailable. 


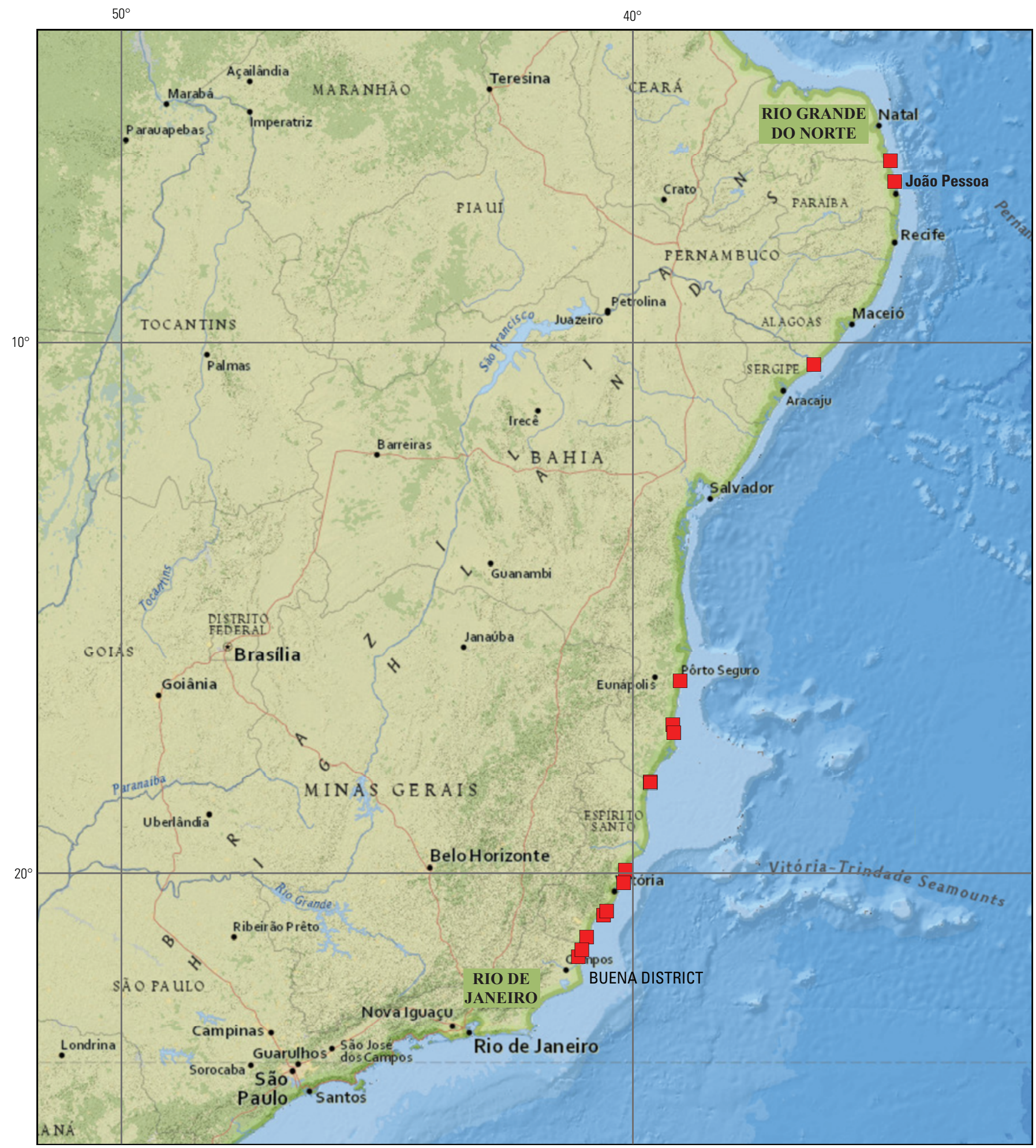

Figure 5. Central coastline of Brazil showing past and present monazite-producing placer deposits (red squares). The only active monazite producer in 2013 is the Buena district (Indústrias Nucleares do Brasil SA (INB), 2013), the southernmost placer district shown on the map. 
Some of the productive monazite-bearing placer districts in southern China (fig. 6) (Jackson and Christiansen, 1993; Orris and Grauch, 2002) are listed below.

- Beihai district $\left(21^{\circ} 29^{\prime}\right.$ N., $109^{\circ} 06^{\prime}$ E., Guangxi province): A mixture of river and marine placers along the coast contains about 1.5 percent heavy minerals comprising ilmenite, rutile, zircon, and monazite. A producer of byproduct monazite.

- Haikang district, $\left(20^{\circ} 56^{\prime}\right.$ N., $110^{\circ} 04^{\prime}$ E., Guangdong province): A mixture of river and marine placers contains ilmenite, zircon, rutile, monazite, and xenotime. A producer of byproduct monazite.

- Dianbai district $\left(21^{\circ} 30^{\prime}\right.$ N., $111^{\circ} 01^{\prime}$ E., Guangdong province): Placers on the coast contain about 2.3 percent heavy minerals comprising ilmenite, rutile, zircon, and monazite. A producer of byproduct monazite.

- Nanshanhai district $\left(21^{\circ} 32^{\prime} 45^{\prime \prime}\right.$ N., 111 $41^{\circ} 00^{\prime \prime}$ E., Guangdong province): Coastal placers contain ilmenite, zircon, rutile, monazite, and xenotime. A producer of byproduct monazite.

- Sai-Lao, Wuzhaung, and Xinglong placer districts (Hainan Island): Placers contain ilmenite, zircon, anatase, cassiterite, monazite, magnetite, and chromite. Producers of byproduct monazite (Orris and Grauch, 2002).

Many other monazite-bearing deposits in China, including alluvial and shoreline types, have been exploited for monazite but information in the English literature is lacking.

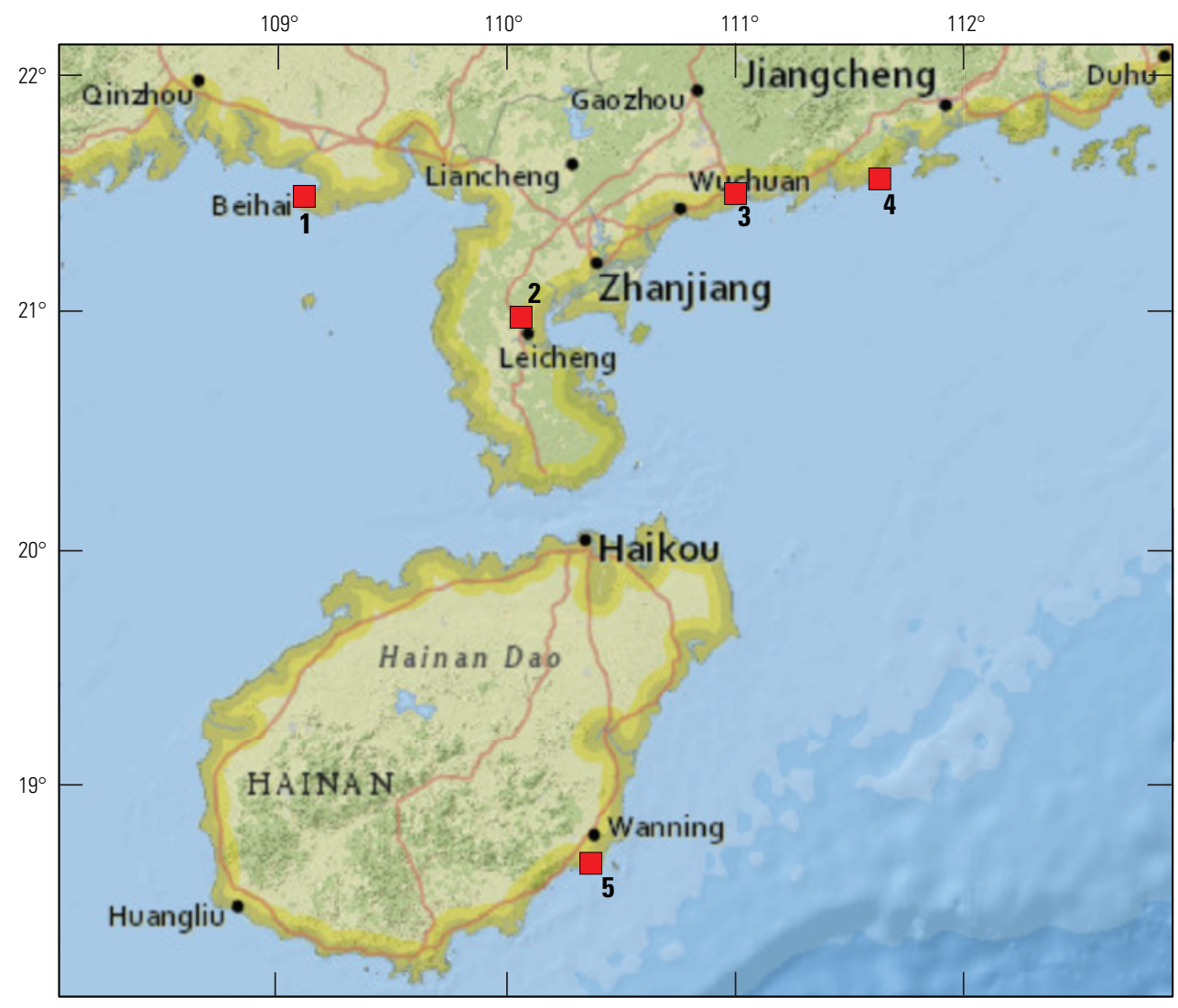

Figure 6. Southernmost China showing selected monazite-bearing placer districts that are described in the text.

1. Beihai district

2. Haikang district

3. Dianbai district

4. Nanshanhai district

5. Sai-Lao, Wuzhaung, and Xinglong placer districts 


\section{India}

The southern coasts of India contain extensive deposits of heavy-mineral sands, such as ilmenite-rich beach and dune sand deposits along the coasts of the States of Kerala (Chavara), Tamil Nadu (Manavalakurichi, Midalam, Vayakallur deposits), Andhra Pradesh (Kakinada, Pentakota, Bhimunipatnam, Konada-Kandivalasa-Mukumpeta-Bendicreek-Donkuru deposits), Odisha (formerly Orissa) (Sanaekasangi-Gopalpur, Chatrapur, Bajarkot, Satpara, Puri deposits), and Maharashtra (Kalbadevi, Newre, Malgund deposits) (fig. 7) (Ali and others, 2001). In the southeastern and southwestern coastal areas of southernmost India, deposits of detrital heavy minerals occur in piedmont lakes, sand bars across the mouth of rivers, deltas, sand dunes behind the beaches, the shallow ocean floor, and the beach (Bhola and others, 1958). Ali and others (2001) report that the Indian resources of coastal placer minerals are estimated at $348 \mathrm{Mt}$ of ilmenite, $107 \mathrm{Mt}$ of garnet, $21 \mathrm{Mt}$ of zircon, $18 \mathrm{Mt}$ of rutile, $8 \mathrm{Mt}$ of monazite and $130 \mathrm{Mt}$ of sillimanite; they suggest these quantities represent about 35 percent of the global resources of ilmenite, 10 percent of rutile, 14 percent of zircon, and 71.4 percent of monazite.

Beaches on the southwestern coast of India have been mined for heavy minerals for more than a century. Beach sands at Manavalakurichi (fig. 7) were first worked in 1911, primarily for their titanium minerals, supplying feedstock for the rapid development of the Ti-oxide pigment industries in Europe and the United States. Development of the region's shore sands followed the discovery of monazite in these beaches in 1909 (The Kerala Minerals \& Metals Limited, 2013). Beach deposits along the Arabian Sea between Chavara and Kollam, Kerala state (fig. 7), also have a long history of heavy-mineral development, which continues today. These deposits are currently mined and processed by The Kerala Minerals \& Metals Limited (2013), which extracts rutile, leucoxene, and ilmenite and further processes them to produce Ti-oxide pigments, along with zircon, sillimanite, and monazite as coproducts.

Also in the Kerala state, about $10 \mathrm{~km}$ north at Kollam (fig. 7), Indian Rare Earths Limited (2013) mines and processes heavy-minerals sands that are rich in ilmenite, rutile, and zircon. The company operates a processing plant about $25 \mathrm{~km}$ north of Kanyakumari (Cape Comorin, the southern tip of India) that "annually produces about 90,000 t ilmenite of 55 percent $\mathrm{TiO}_{2}$ grade, 3,500 $\mathrm{t}$ rutile and 10,000 $\mathrm{t}$ zircon in addition to 3,000 $\mathrm{t}$ monazite and 10,000 $\mathrm{t}$ garnet based primarily on beach washing supplied by fishermen of surrounding five villages" (Indian Rare Earths Limited, 2013).

The eastern and western shores of southern India host one of the largest thorium resources in the world; thorium is found in detrital grains of monazite within the heavy mineral suite of coastal sands. Mahadevan and others (1958) evaluated the ilmenite and monazite content of about 1,000 acres of beach sands along the southern tip of India and found that these sands contain estimated reserves of 492,000 $t$ of monazite; the monazite averaged 0.75 weight percent of the raw beach sand samples. Monazite is recovered from beach sands along the southwestern coast in Kerala state (Sabha, 2011; Kerala Minerals \& Metals Limited, 2013), obtained as a coproduct with ilmenite, leucoxene, and rutile as the primary products. The monazite is stockpiled as part of a government-industry cooperative designed to provide source material for thoriumbased nuclear power under development by the Department of Atomic Energy of the Indian government. The typical composition of monazite from the Kerala deposits is reportedly 57.5 percent REE oxide and 7.96 percent Th oxide (Kerala Minerals \& Metals Limited, 2013). Monazite is currently processed by the Rare Earths Division of Indian Rare Earths Limited (2013).

Heavy-mineral bearing beach deposits of similar characteristics also exist on the coast of southeastern India. The Trimex Group is developing the Srikurmam heavy-mineral sands deposit, covering an area of $7.2 \mathrm{~km}^{2}$ of the shoreline along the Bay of Bengal, about $15 \mathrm{~km}$ southeast of Srikakulam, in the Andhra Pradesh State (fig. 7). The company plans to produce ilmenite, rutile, zircon, garnet, and sillimanite from this deposit (Trimex Industries, 2013).

Farther north on the east coast of India, along the coastlines of the Odisha State (formerly Orissa), many beach sands and coastal sand dunes have a substantial heavy-mineral content. An 18-km-long deposit between the mouth of the Rushikulya River at Ganjam and the town of Gopalpur (fig. 7) has been referred to as the Chhatrapur Mineral Sands Deposit. A study of the heavy minerals in beach sands of this area by Behera (2003) found high concentrations of sillimanite (as much as 50 percent), as well as ilmenite, garnet, rutile, and monazite. On the coast near Chhatrapur (fig. 7), Indian Rare Earths Limited (2013) operates a dredging mine and separation plant to recover sillimanite, garnet, rutile, ilmenite, and monazite.

\section{Kenya}

Base Resources Limited plans to produce ilmenite, rutile, and zircon from their Kwale mineral sands project (fig. 8), located about $50 \mathrm{~km}$ southwest of Mombasa and $10 \mathrm{~km}$ inland from the coast. The Kwale deposit is interpreted to be hosted by ancient coastal dunes, which locally hold high concentrations of heavy minerals. The company reports an estimate for the Kwale deposit of $146 \mathrm{Mt}$ of measured plus indicated resources (combined) grading 4.89 percent heavy-minerals; an estimated 2.59 percent of the deposit is ilmenite, 0.65 percent is rutile, and 0.29 percent is zircon (Base Resources Limited, 2013).

\section{Madagascar}

Near Taolagnaro in southeastern Madagascar, QIT Madagascar Minerals SA (QMM) has produced ilmenite and zircon from ancient beach sands at their Fort Dauphin mine since 2009 (fig. 8) (Rio Tinto, 2013). Their operation uses dry and dredge mining techniques. 


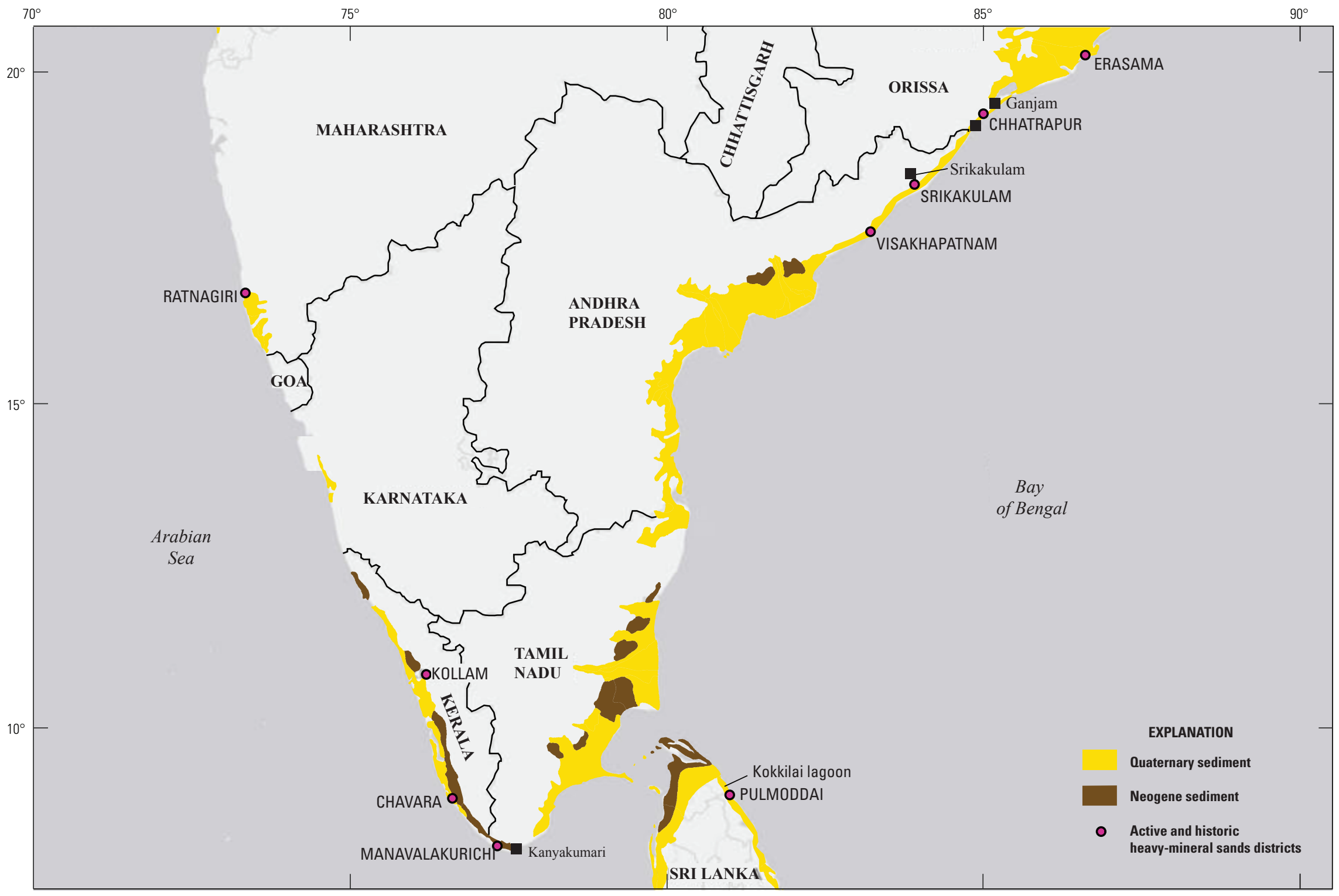

Figure 7. Southern India and northern Sri Lanka showing locations of historical and active heavy-mineral sands operations discussed in this report and areas of Quaternary and Neogene sediments. 


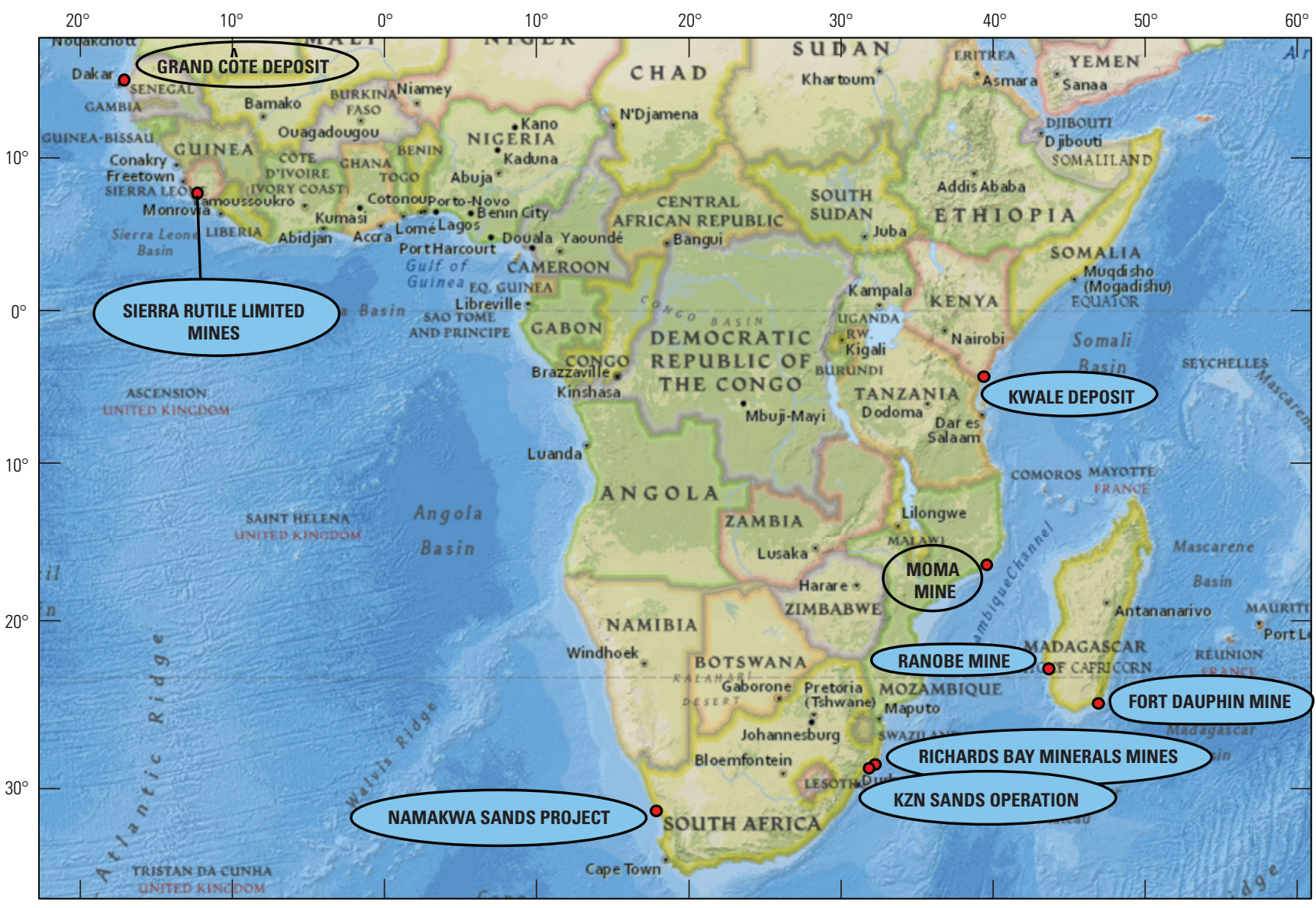

Figure 8. Part of Africa showing locations of active heavy-mineral-sands operations and advanced projects that are discussed in this report.

North of Toliara in southwestern Madagascar, inland but paralleling the coast, World Titanium Resources (2013) has plans to open a heavy-mineral sands operation in 2014. The company refers to its proposed development site as the Ranobe mine (fig. 8), a part of their Toliara Sands Project. They report that the initial Ranobe mine plan will focus on an ore reserve of $161 \mathrm{Mt}$ of sands averaging 8.2 percent heavymineral content (World Titanium Resources, 2013). They indicate that approximately 90 percent of the deposit's heavymineral suite is ilmenite; zircon would also be recovered and sold. The company has additional deposits of heavy-mineral sands under investigation within their project area.

\section{Mozambique}

On the northeast coast of Mozambique, Kenmare Resources plc (2013) operates the Moma heavy-minerals mine and processing facilities (fig. 8), using dredge mining techniques in artificial ponds to excavate sands containing ilmenite, rutile, and zircon. The primary orebody reportedly contains proved and probable reserves of $869 \mathrm{Mt}$ of sand with 3.7 percent heavy-mineral content; the heavy minerals comprise 83 percent ilmenite, 2 percent rutile, and 6 percent zircon (Kenmare Resources plc, 2013).

\section{Senegal}

Mineral Deposits Limited commenced mining their Grande Côte heavy-mineral sands deposit in late 2013 (Mineral Deposits Limited, 2013). The permitted mine project area includes a mobile dune field that parallels the shore, beginning about $50 \mathrm{~km}$ northeast of Dakar (fig. 8). The dune system is approximately $100 \mathrm{~km}$ long and $4 \mathrm{~km}$ in width. The company reports a total measured and indicated resource estimate of $1,030 \mathrm{Mt}$ of 1.73 percent heavy mineral at a 1.25 percent cutoff grade; the proved and probable ore reserve estimate is 751 Mt of 1.8 percent heavy mineral (Mineral Deposits Limited, 2013). Principal products are zircon and ilmenite, with smaller amounts of rutile and leucoxene. 


\section{Sierra Leone}

Sierra Rutile Limited (formerly Titanium Resources Group Limited) conducts dredge and dry-land mining of heavy-mineral sands near Mokaba in southwestern Sierra Leone (fig. 8). These deposits are enriched in rutile and may represent the world's largest primary rutile resource. Sierra Rutile Limited reports a measured and indicated resource of $441 \mathrm{Mt}$ of sands containing 6.14 percent heavy minerals; the sands contain 1.48 percent rutile, 0.74 percent ilmenite, and 0.31 percent zircon (Sierra Rutile Limited, 2013).

\section{South Africa}

Titanium mineral recovery from Quaternary heavymineral sands began in 1977 in the Richards Bay area (Richards Bay Minerals, 2013) on the east coast of South Africa. A substantial heavy-minerals producer in the district is Richards Bay Minerals (2013), which recovers zircon, rutile, and ilmenite from dune sands located $30 \mathrm{~km}$ to the north of Richards

Bay (fig. 8). During the early 2000s, this heavy-minerals operation produced about 25 percent of the world's supply of rutile, ilmenite, and zircon (Tyler and Minnitt, 2004).

Also near Richards Bay, Tronox operates the KZN Sands operation (fig. 8), which includes the Hillendale mine about $15 \mathrm{~km}$ southwest of Richards Bay (Tronox, 2013). Their operations focus on recovery and processing of ilmenite, rutile, and leucoxene to produce titanium dioxide feedstock.

On the west coast of South Africa, Tronox also operates the Namakwa Sands project at Hondeklip Bay (fig. 8) (Tronox, 2013). The company mines on dry land by open-pit methods, recovering titanium minerals and zircon.

\section{Sri Lanka}

Modern beach deposits on the northeastern coast of Sri Lanka have some of the highest concentrations of heavy minerals in the world. The beach sands are mined and processed by Lanka Minerals Sands Limited (2013), a company owned by the Government of Sri Lanka. The company's primary mining operations and processing plants are located just east of Pulmoddai on the northeastern coast of Sri Lanka (fig. 7). Products from the beach sands are ilmenite, rutile, and zircon; sillimanite, monazite and garnet are also present. Monazite composes 0.3 percent of the heavy mineral fraction (Herath, 1990). In some locations, the heavy minerals can form as much as 90 percent of the sand deposits; ilmenite forms 65 percent of the heavies, rutile forms 10 percent, and zircon forms 10 percent (Lanka Minerals Sands Limited, 2013). Heavy-mineral-rich beach sands extend along the shore about $8 \mathrm{~km}$ south from Kokkilai Lagoon and they extend inland from the ocean for about $370 \mathrm{~m}$. The $72-\mathrm{km}$-long stretch of beach in northeastern Sri Lanka may represent the richest deposit of heavy-mineral sands in the world (Lanka Minerals Sands Limited, 2013).

Monazite-bearing alluvium in southwestern Sri Lanka, specifically stream sediments of the Bentota Ganga River (fig. 9), have been described as "one of the world's most thorium-rich sediments" (Rupasinghe and others, 1983, p. 1). This river system drains a region whose bedrock is mainly charnockitic gneiss and garnetiferous gneiss. The Bentota Ganga River moves monazite with other heavy minerals, which are deposited in seasonal beach sand deposits extending from Beruwala (fig. 9) south to Kikawala beach, a distance of about $12 \mathrm{~km}$ along the coast. Monazite was once mined on a small scale at Kaikawala beach. Analyses of these monazites by Rupasinghe and others (1983) showed them to be highly enriched in the light REEs relative to the heavy REEs, with a negative Eu anomaly when the analyses were normalized to chondrite values (Rupasinghe and Dissanayake, 1984).

Deposits of ilmenite-rich sands are also known to exist along the northwestern coast of Sri Lanka (Murphy and Frick, 2006). However, published descriptions of these deposits are lacking.

\section{Ukraine}

Velta LLC initiated production in 2012 from the Birzulivske heavy-mineral sands deposit in Kirovohrad oblast (province) of central Ukraine (the exact location is not reported). Ilmenite is the primary product of this operation, which has estimated ilmenite reserves of $5 \mathrm{Mt}$ (Velta LLC, 2013). The deposit is mined by open pit. The heavy-mineral deposit occupies an area $5.5 \mathrm{~km}$ long by $2.5 \mathrm{~km}$ wide; the average thickness of the ore zone is $6.4 \mathrm{~m}$ (Velta LLC, 2013).

The Volchanske heavy-mineral sands deposit is located in Dnipropetrovsk oblast (province), Ukraine (the exact location is not reported). The deposit extends for more than $20 \mathrm{~km}$ and is as wide as $1 \mathrm{~km}$, with an ore zone that averages $7.4 \mathrm{~m}$ in thickness. The sands of this deposit have an average heavymineral content of 9.2 percent provided by ilmenite, rutile, sillimanite, staurolite, and zircon.

\section{United States}

Virginia-North Carolina-South Carolina-Georgia. Berquist (1987) was the first to recognize and report heavymineral-rich sand deposits in southern Virginia. His report prompted exploration for this deposit type in southeastern Virginia, leading to the discovery of the Old Hickory deposits subsequently mined by Iluka Resources. The heavy mineral deposits of this belt developed in the upper Coastal Plain, just east of the Fall Zone (fig. 10) - the contact zone between the basement rocks of the Piedmont region on the west and much younger sediments of the Coastal Plain on the east. Heavymineral sands in the western parts of the Coastal Plain of Virginia and North Carolina, along the Fall Zone, are interpreted 


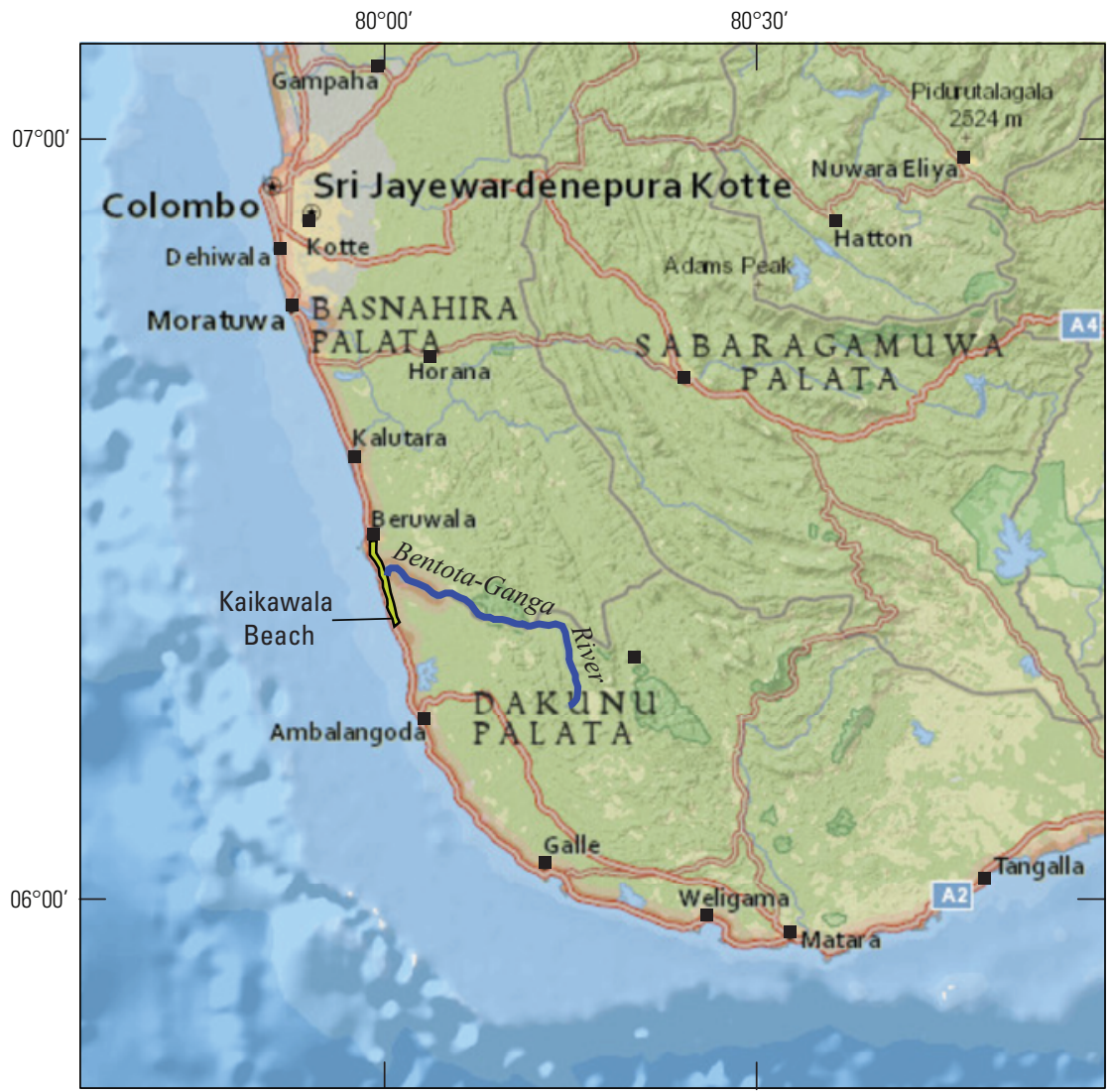

Figure 9. Southwestern Sri Lanka showing the Bentota-Ganga River. The stream sediments of the Bentota-Ganga River have been described as "one of the world's most thorium-rich sediments" (Rupasinghe and others, 1983, p. 1). Monazite and other heavy minerals are transported by this river, which deposits them in seasonal beaches that extend from near Beruwala on the north to Kaikawala Beach on the south (outlined in black).

to be Pliocene sedimentary deposits that formed during worldwide transgression-regression events between 3.5 and 3.0 million years ago (Ma) (Carpenter and Carpenter, 1991). On the basis of heavy-mineral estimates for 19 deposits within this belt, Carpenter and Carpenter (1991) calculated a total regional resource of $22.7 \mathrm{Mt}$ of heavy minerals in $377.8 \mathrm{Mt}$ of sand, with an average heavy-mineral content of 6 percent. Average mineral distribution within the heavy mineral suite was estimated to be 60 percent ilmenite, 2.5 percent rutile, 12.5 percent zircon, 8.5 percent staurolite, 0.7 percent tourmaline, 3.0 percent kyanite, 1.3 percent sillimanite, and 11.5 percent other heavy minerals (mostly limonite) (Carpenter and Carpenter, 1991).

In southeastern Virginia, Iluka Resources actively mines deposits of heavy-minerals sands of Pliocene and possibly Miocene age from the Concord mine in Sussex County and Brink mine in Greensville County (figs. 10 and 11). Along this same Pliocene-Miocene strandline in Virginia, Iluka Resources has selected another proposed mine site called Hickory

(fig. 10), which is located between the city of Richmond to the north and the Concord mine to the south (see Iluka Resources, 2013a). In this same area, Iluka Resources previously mined out the nearby Old Hickory deposit (fig. 10); this mine site is currently being remediated. For their entire holdings of heavymineral deposits in this Atlantic Seaboard region, the company reports proven and probable resources of $34.7 \mathrm{Mt}$ that average 4.4 percent heavy-mineral content; ilmenite composes about
64 percent of the heavy minerals and zircon composes about 16 percent (Iluka Resources, 2013a). The company produces final products of chloride ilmenite, zircon, and staurolite from their Virginia operations.

A northeast-trending zone of heavy-mineral sand deposits, about $160 \mathrm{~km}$ in length, is described by Carpenter and Carpenter (1991) as the "North Carolina-Virginia heavy mineral belt." The northern end of this belt includes the previously described Hickory deposit and the belt's south end includes deposits located west of Wilson, North Carolina (Carpenter and Carpenter, 1991, fig. 1). The Aurelian Springs deposit, midway along this belt in northeastern North Carolina, is another proposed mine site (Iluka Resources, 2013a).

Florida. An elongate, north-south-trending ridge of sand in northeastern Florida named Trail Ridge has been mined by DuPont for heavy-minerals for more than 60 years (fig. 12). DuPont geologists discovered these deposits in 1947, and mining began in 1949 (Carpenter and others, 1953). DuPont began their open-pit mining and heavy-mineral processing facilities on the southern end of Trail Ridge, east of the town of Starke. Subsequent mining has progressed northward along the ridge of sand to the vicinity of MacClenny. Trail Ridge is composed of Pliocene-age bodies of aeolian sand with an average heavymineral content of about 4 percent (Force and Rich, 1989).

The aeolian sand complex that forms the Trail Ridge orebody is 1 to $2 \mathrm{~km}$ wide and about $11 \mathrm{~m}$ thick. Mining and exploration confirm that economic grades of heavy minerals continue 


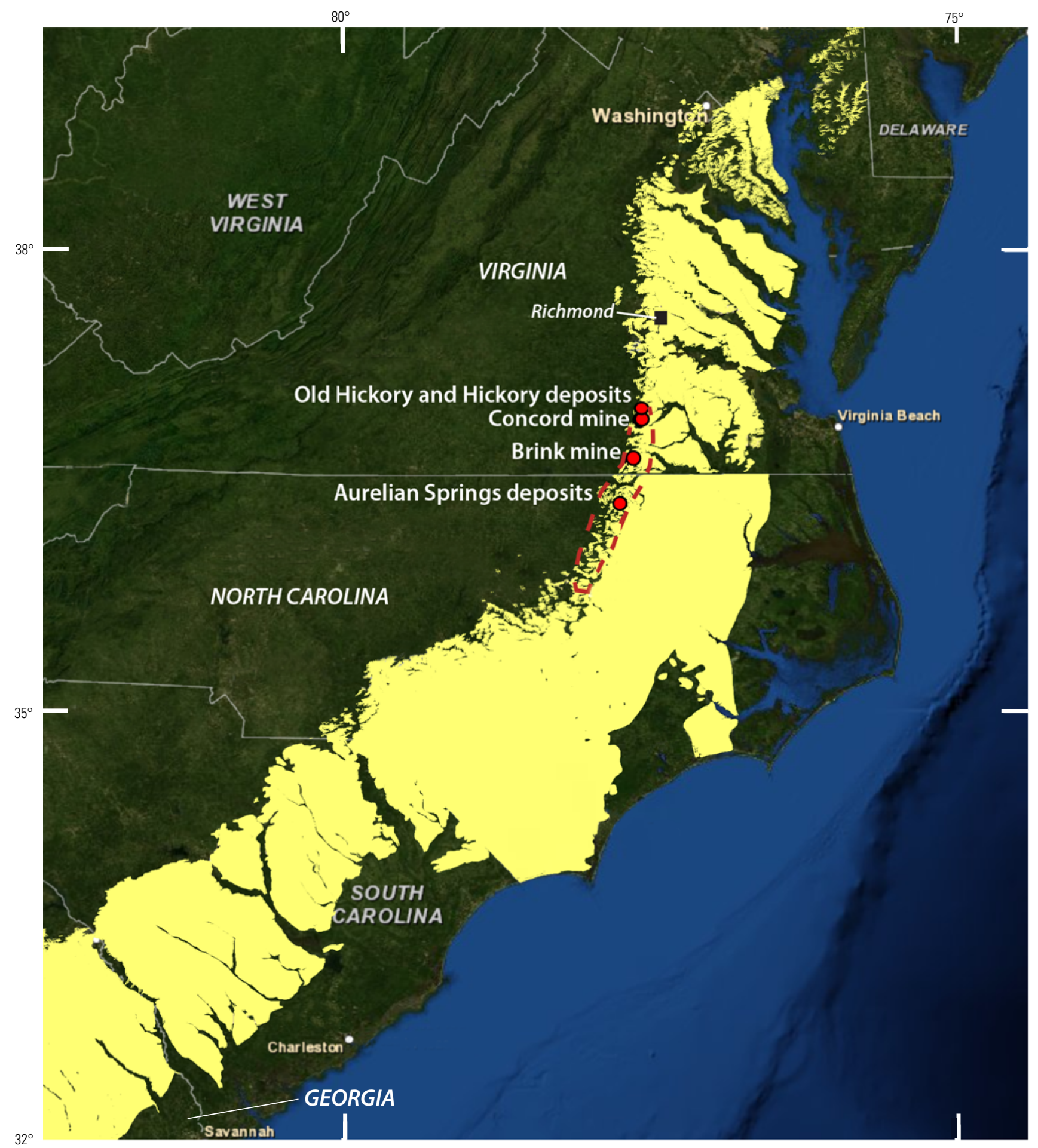

Figure 10. Southeastern United States showing the extent of Late Cretaceous and Tertiary (Paleogene and Neogene) sediments in the coastal plain of this region. These sediments were deposited along and east of the "Fall Zone" in the upper Coastal Plain (yellow band), as explained in the report. Red dots, the two active heavy-mineral sands operations in this region (the Concord and Brink mines of lluka Resources, southern Virginia), and their Hickory deposit (proposed for development). Red dashed outline, the North Carolina-Virginia heavy mineral belt, as described by Carpenter and Carpenter (1991). 


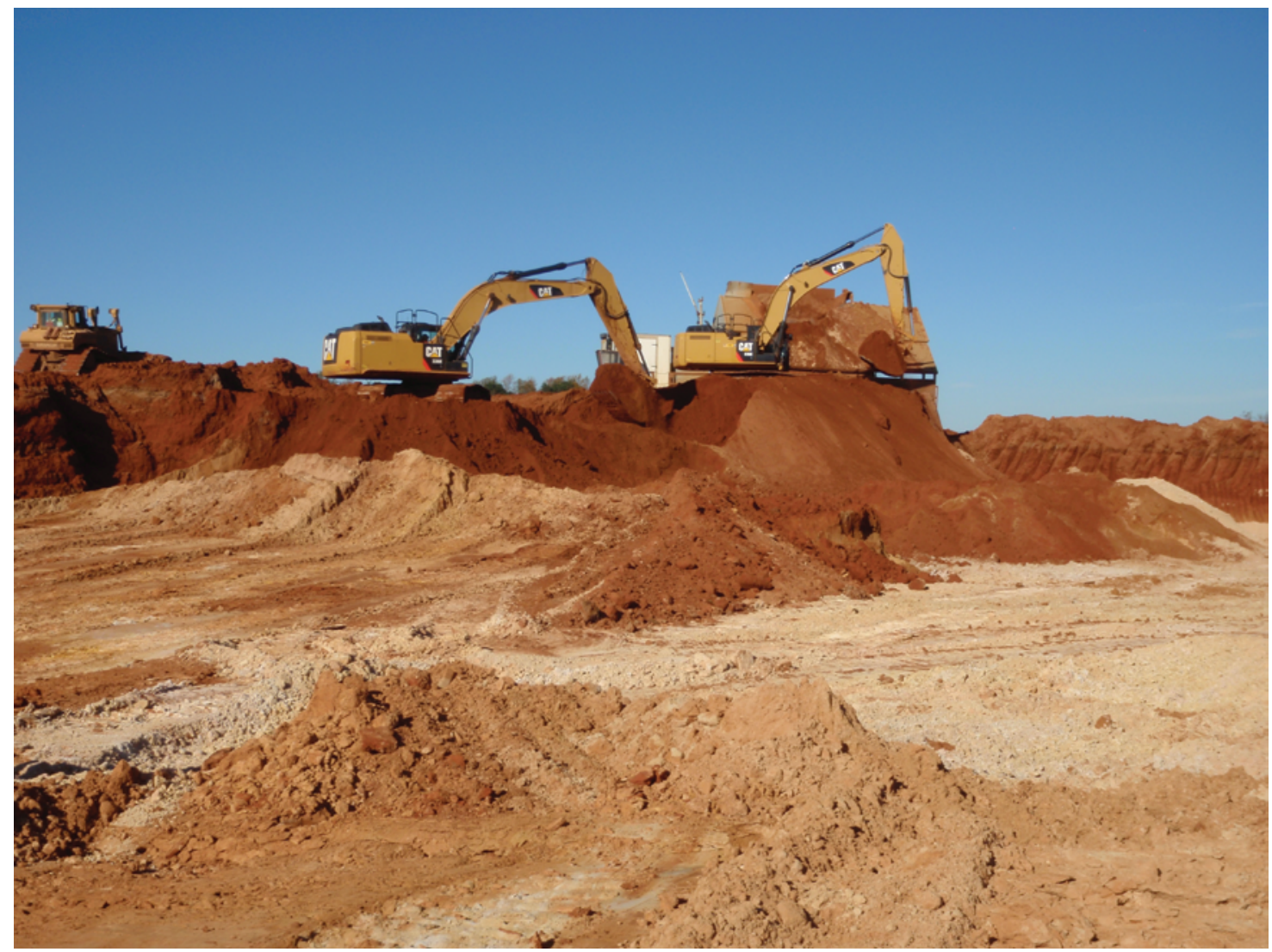

Figure 11. The Concord heavy-mineral-sands mine in south-central Virginia (Iluka Resources, 2013a). The mine excavates weakly consolidated Pliocene-age sand-silt deposits that contain about 4 percent heavy minerals. These ores are processed at nearby separation plants. The principal products are ilmenite, leucoxene, rutile, and zircon; accessory heavy minerals that are not sold are staurolite, kyanite/sillimanite, and monazite.

along Trail Ridge for at least $40 \mathrm{~km}$. DuPont produces titanium minerals, zircon, and staurolite from these deposits.

Whereas Trail Ridge is located about $65 \mathrm{~km}$ inland from the ocean, other heavy-mineral sands mined in the past in northern Florida lie closer to the coast. The historical accounts of early heavy-mineral sands operations in Florida, summarized below, are based on descriptions by Overstreet (1967) and Staatz and others (1980).

Modern beach sands near Mineral City, now known as Ponte Vedra, were mined chiefly for ilmenite from 1916 to 1929 (Staatz and others, 1980), about $1 \mathrm{~km}$ west of the ocean and east of Jacksonville. Reportedly, 1.0 t of monazite was produced in 1925 (Staatz and others, 1980). From 1943 to 1968, the Rutile Mining Co. recovered ilmenite, rutile, zircon, and small amounts of monazite from Pleistocene and Pliocene beach sands just east of Jacksonville.

Beginning in 1940, the Riz Mineral Co. recovered ilmenite, zircon, and rutile from modern beach sands near Melbourne in the central area of Florida's east coast (south of coastline shown in fig. 12). The company also mined dune sands near Vero Beach (also south of coastline shown in fig. 12) from the early 1940 s until 1955 , recovering ilmenite, rutile, zircon, and monazite (Staatz and others, 1980).

From 1972 to 1978, Titanium Enterprises, Inc., mined Pleistocene beach deposits near Green Cove Springs, located south of Jacksonville and west of St. Johns River. Iluka Resources later resumed mining from this deposit, ending their mining activities there in 2005 (Iluka Resources, 2013a); the site is now being reclaimed by the company. The deposit at Green Cove Springs contained an average of 3 percent heavy minerals that included ilmenite, leucoxene, rutile, zircon, and monazite (Staatz and others, 1980).

From 1974 to 1978, Humphrey Minerals mined a Pleistocene shoreline deposit near Boulogne in northeastern Florida. This orebody averaged about 4 percent heavy minerals; titanium minerals, zircon, and monazite were recovered. Reportedly, monazite composes $0.3-0.4$ percent of the heavy-mineral assemblage in this deposit (Staatz and others, 1980). This Pleistocene shoreline facies extends to the north, where this unit was earlier mined by the same company near Folkston, Georgia. 


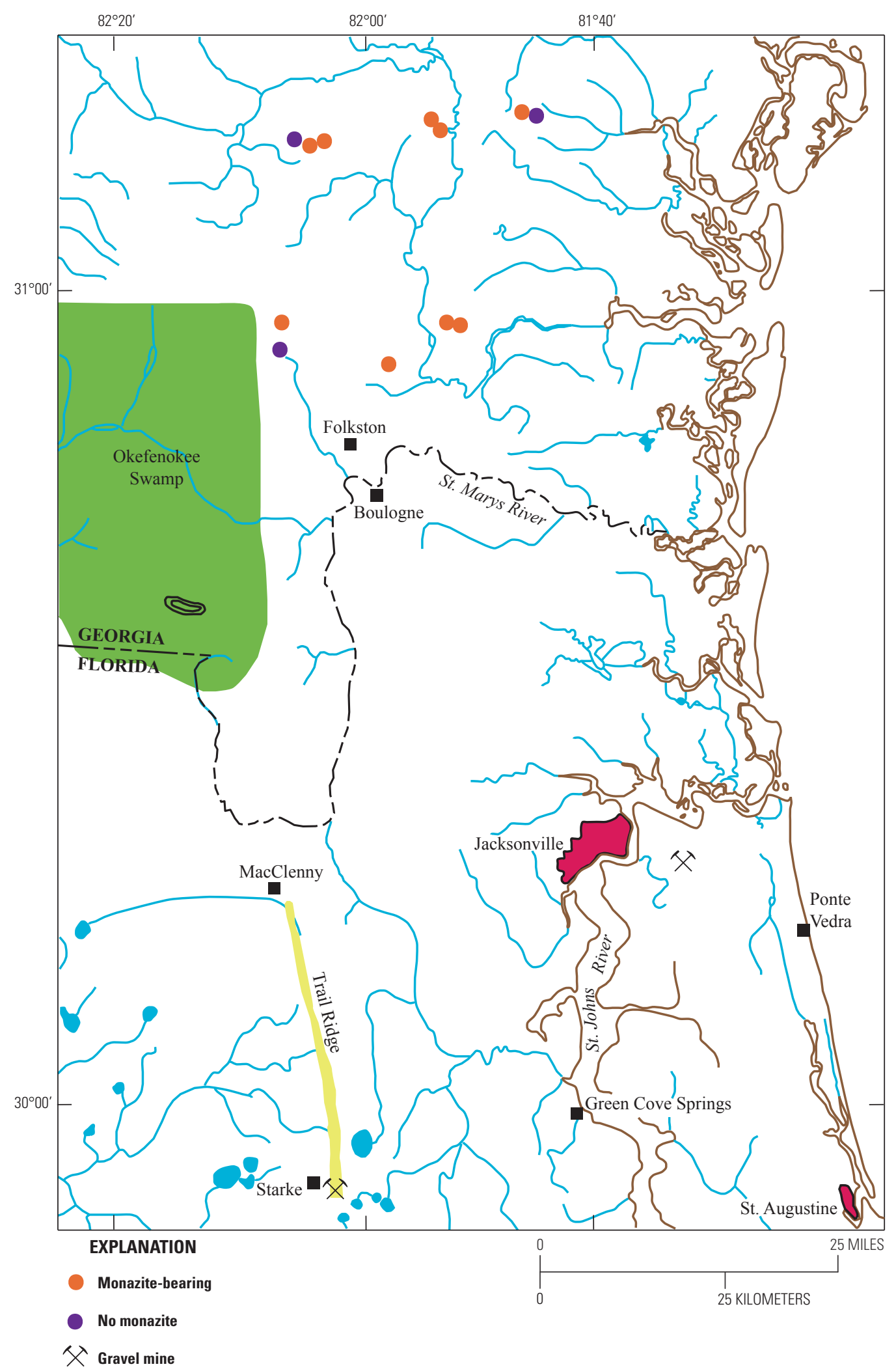

Figure 12. Locations of heavy-mineral-sands samples and mines in southeastern Georgia and northeastern Florida. Modified from Mertie (1975). 
Modern beaches and offshore islands along the east coast of Florida contain deposits of heavy minerals. However, the heavy-mineral resources in the modern beaches along Florida's Atlantic coast are unlikely to be developed in the foreseeable future because the beach-front and adjacent coastal lands are far more valuable as sites for real estate investment than as mining leases, and applications to mine in areas near the seashore would likely face much opposition. Additionally, Overstreet (1967, p. 125) explains that "the ancient inland buried beach and dune deposits [in northern Florida] are preferred to the Recent (Holocene) beach deposits despite their lower tenor, because the ancient deposits are larger, have more uniform distribution of heavy minerals, and are not as vulnerable to severe storms..

New Jersey. From 1962 to 1982, the Lakehurst district of southern New Jersey (fig. 13) was a principal supplier of altered ilmenite, which was produced by two companies that mined from open pits in the Neogene Cohansey Sand. Its highest-grade intervals are about $5 \mathrm{~m}$ thick and contain 5-25 percent heavy minerals (Puffer and Cousminer, 1982; Force, 1991). Carter (1978) interpreted that the Cohansey Sand is most greatly enriched in heavy minerals near the top of the swash zone along the Tertiary beach. Puffer and Cousminer (1982) interpret that the sands were deposited during a period of erosion between the Miocene and Pliocene that

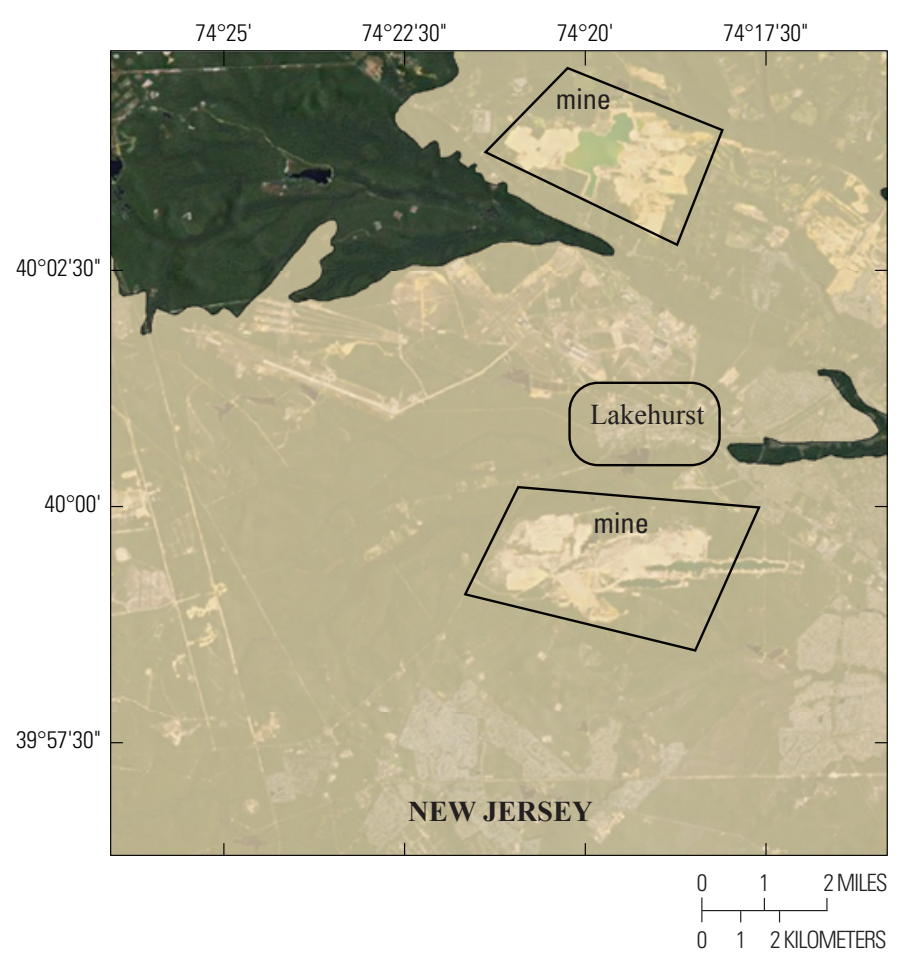

Figure 13. The Lakehurst area, New Jersey, showing locations of former heavy-mineral-sands mines. From 1962 to 1982, these mines exploited intervals with 5-25 percent heavy minerals within the Cohansey Sand (beige color). coincided with a marine regression. The heavy minerals in the unit are dominated by altered ilmenite ( 85 percent), as well as zircon ( 7 percent), sillimanite ( 3 percent), staurolite (1 percent), and tourmaline (1 percent) (Puffer and Cousminer, 1982).

Tennessee. The McNairy Sand, about 50-100 m thick, is the shoreline facies of a Late Cretaceous transgressiveregressive sequence in the Mississippi embayment from Mississippi to southern Illinois (Force, 1991). The basal member of the McNairy Sand, which is as much as $15 \mathrm{~m}$ thick, contains concentrations of heavy minerals that are locally as high as 17 percent (Wilcox, 1971). The heavy mineral suite averages 55 percent ilmenite, 8 percent leucoxene, 2 percent rutile, 10 percent zircon, and 1 percent monazite (Force, 1991); staurolite, kyanite, and tourmaline are also present (Wilcox, 1971).

The McNairy Sand underlies a district from just south of Bruceton, Tennessee, to Natchez Trace State Park, Tennessee, on the south (fig. 14), but the unit is generally poorly exposed. The McNairy Sand is best exposed on bluffs and in several silica sand pits southeast of Bruceton. Other exposures of the McNairy Sand in western Tennessee are described by Wilcox (1971) and Force (1991). Studies by Hunter (1968) indicate that the heavy-mineral contents are only about 1 percent within the McNairy Sand in Kentucky and southern Illinois.

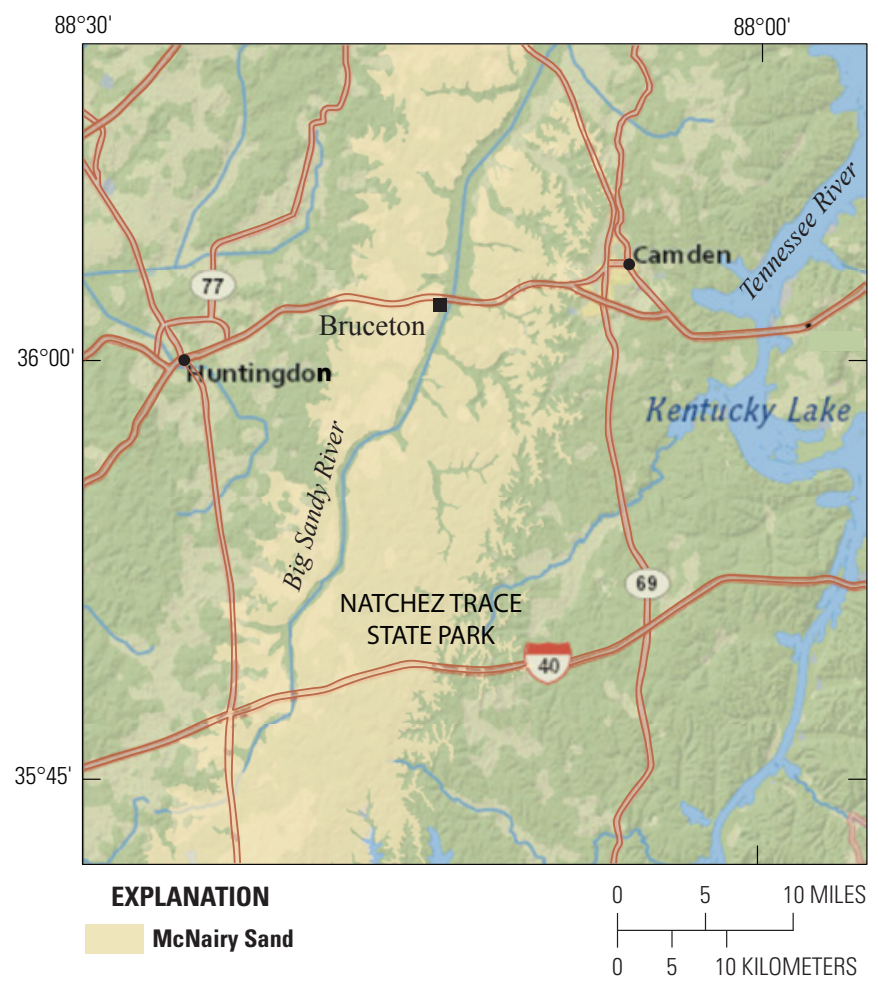

Figure 14. Extent of the Late Cretaceous McNairy Sand in the area surrounding Bruceton, western Tennessee. 


\section{Vietnam}

Deposits of heavy-mineral sands are known at many places along the Vietnam coastline for a distance of more than $1,500 \mathrm{~km}$. The largest heavy-mineral sands deposits are in the Binh Thuan province of southern Vietnam, parallel to the coast (fig. 15). Reportedly, the Binh Thuan province contains about $599 \mathrm{Mt}$ of titanium reserves, which is about
92 percent of Vietnam's known total titanium reserves (GPM Asia, 2013); the province also contains the largest reserves of zircon in Vietnam (Amigo Holdings, 2013). In this area, GPM Asia (2013) produces ilmenite, zircon, rutile, and monazite from coastal heavy-mineral sands. Another heavy-mineral sands operator in the Binh Thuan province is Amigo Minerals, which likewise produces ilmenite, zircon, rutile, and monazite (Amigo Holdings, 2013).

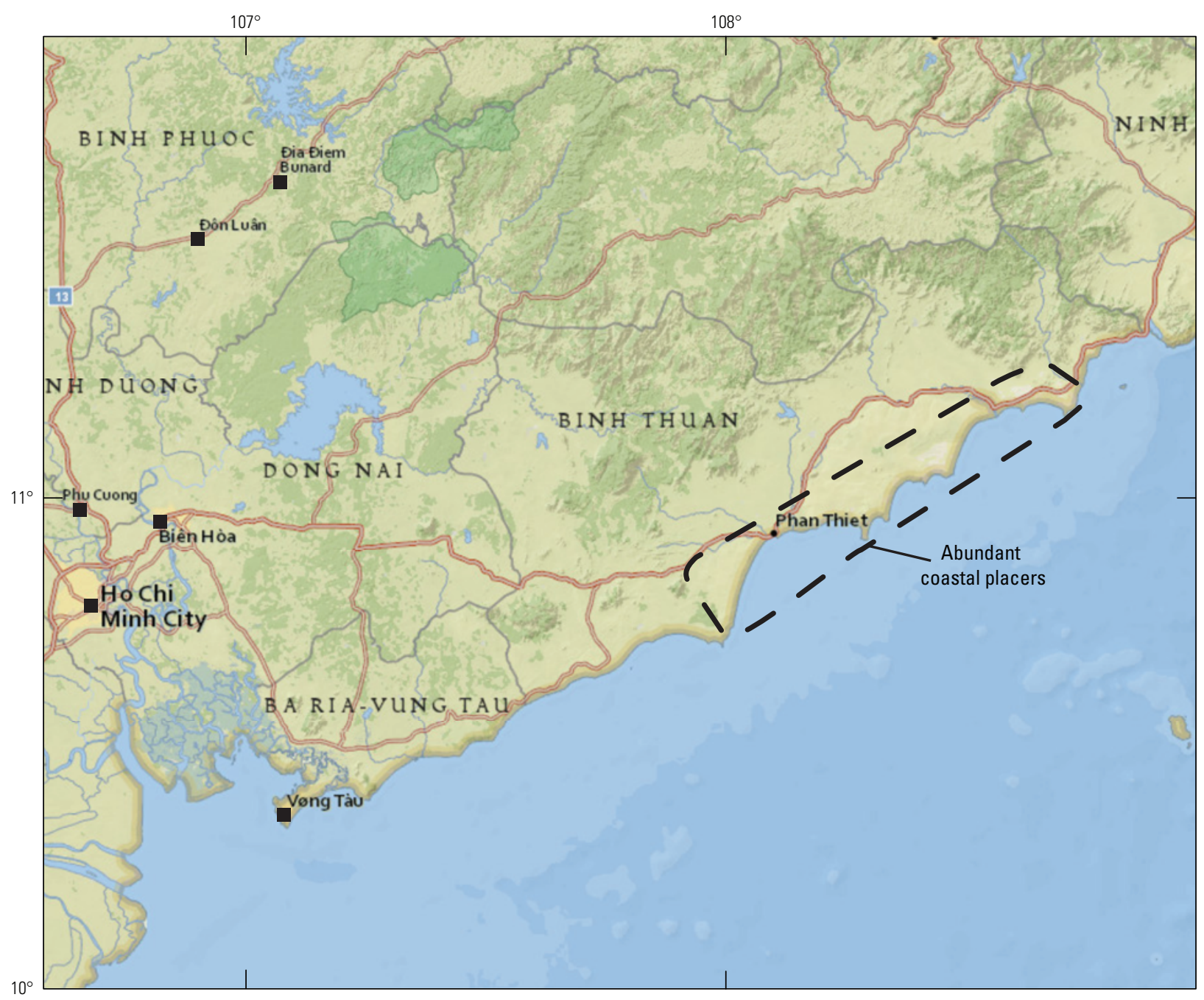

Figure 15. Southeastern Vietnam outlining the general area containing the largest, most productive heavy-mineralsands deposits in Vietnam. 


\section{Historical Evolution of Descriptive and Genetic Knowledge and Concepts}

The history of heavy minerals research from its infancy is best summarized in a book edited by Luepke (1984). Some of the major benchmarks in heavy minerals research, as explained by Luepke (1984, p. 1-12) are briefly noted here.

- "The earliest use of the term minéraux lourds (heavy minerals) appears to be in René Breón's [1880] paper on mineral separation" (Luepke, 1984, p. 1).

- Boswell (1933) credited the first description of the petrography of sands to a 1718 paper by René Antoine Ferchault de Réaumur.

- "Before the invention of thin sections (1849) and heavy liquids (c. 1880), heavy minerals in sizes less than 0.25 millimeters $(\mathrm{mm})$ were not extensively studied" (Luepke, 1984, p. 2). Research on heavy minerals before 1870 was only descriptive; it lacked interpretation of mineral sources and processes of deposition.

- The first insightful report on heavy minerals is often credited as a two-page report published in Nature in 1887 (Dick, 1887), which provided detailed petrologic descriptions, and also postulated on processes of deposition for several heavy-mineral-bearing sand deposits in Great Britain.

- Research published during the 1890 s contributed the most thorough descriptions of heavy-mineral sands that had existed up to that time, including descriptions of the suites of heavy minerals found in river sands, sand dunes, and lithified sedimentary formations.

- During the first three decades of the 20th century, numerous descriptions of heavy minerals in sediments were published. Research began to include analysis of direction of sediment transport and sources, quantitative mineral proportions, and relations that explain variations in heavy-mineral content and possible bedrock sources.

- The Principles that Regulate the Distribution of Particles of Heavy Minerals in Sedimentary Rocks (Mackie, 1923) is recognized as a classic study, which became the basis for subsequent modern studies of heavy minerals in sedimentary environments.

- A classic paper by W.W. Rubey described many factors that control the distribution of heavy minerals within water-laid sandstones (Rubey, 1933). This paper recognized the role of the physical properties of detrital particles as a primary influence on their sorting in natural environments and set the concepts for the study of grain features, such as diameter and settling velocity, that control the transport and deposition of heavy minerals - the principles of hydraulic equivalence.

- From the 1930 s to the present, much research has been devoted to the chemical and physical stability of heavy minerals in sediments; some of this research is summarized in Luepke (1984) and Force (1991). Heavy minerals have been investigated to determine their resistance to weathering in sediments, resistance to wear during transport (particularly water transport), and the possible alteration effects of intrastratal solutions, burial, and climate.

During the past 40 years, research on heavy-mineral sands went beyond local petrologic descriptions and extended to the study of regional- and global-scale factors that affect the formation and preservation of heavy-mineral sands. As examples, influences on the development of heavy-mineral sands can include (1) sea level fluctuations due to climatic changes (McKellar, 1975; Chappell and Shackleton, 1986; Hou and others, 2006, 2008); (2) tectonics (Hou and others, 2008); (3) extended periods of sea transgression, which move heavy minerals from the shelf onto the shoreface (Roy, 1999); (4) storms, which drive energetic wave swell action (fig. 2) (Force, 1991); (5) longshore drift; and (6) coastline morphology. All of these factors influence the sediment flux to the coast, including heavy minerals, and ultimately the character and preservation of the sedimentary deposits.

Recent research has included reconstructions of the paleocoasts that existed when large-volume heavy-mineralsands ores were deposited during the Cenozoic (Carpenter and Carpenter, 1991; Force, 1991; Hou and Warland, 2005; Lees, 2006; Hou and others, 2011; Reid and others, 2013). These reconstructions provide valuable exploration guides.

\section{Regional Environment}

\section{Geotectonic Environment}

In contrast to most types of ore deposits, heavy-mineral sands are not commonly linked to large-scale tectonic features, such as major fault and fold systems. Economic deposits of coastal heavy-mineral sands are typically found on the passive margins of continents, which generally are not subjected to large-scale tectonism. Pre-1970s models of coastal heavy mineral deposit formation generally assumed tectonic stability.

However, some recent studies have interpreted direct links to tectonics within some coastal basins. Hou and others $(2008,2011)$ indicate that the Eucla basin of southern Australia (fig. 4) experienced differential vertical movements and tilting since the Eocene, which they suggest enhanced the sedimentation and reworking of heavy minerals in the coastal basin. Roy and others (2000) interpret that growth faults 
overlying up-faulted blocks in the Murray basin of southeastern Australia (fig. 4) influenced the distribution of heavymineral sands in the basin. Their observations provide criteria for discovering additional prospective heavy mineral deposits in the Murray basin. The Old Hickory heavy minerals deposit in southern Virginia (Carpenter and Carpenter, 1991) experienced widespread small-offset faulting both before and after deposition (Iluka Resources, written commun., 2012). Winkler and Howard (1977) concluded that shorelines of the southern Atlantic Coastal Plain of the United States (fig. 10) deformed during the Pliocene to Pleistocene, coincident with periods of heavy-mineral deposition.

\section{Temporal (Secular) Relations}

Heavy-mineral-bearing sandstones that represent beaches of the Cretaceous Seaway crop out in the western interior of the United States. Some of these Cretaceous sandstones contain high concentrations of heavy minerals. However, these Cretaceous sandstones are typically well lithified, which reduces the economic appeal of mining these rock units for their heavy mineral deposits. The costs associated with blasting and crushing sandstone, used in the early stages of mining and processing, may render the deposits uneconomic.

In some Quaternary coastal systems, heavy-mineral-rich Cretaceous and Tertiary sandstones can serve as intermediate host rocks for heavy minerals deposits. That is, heavy minerals concentrations in ancient strata can be eroded and transported by a fluvial system and brought to the coast (Leonardos, 1974; Ali and others, 2001), thereby recycling, reconcentrating, and redepositing the heavy mineral suite.

The heavy-mineral sands operations worldwide exploit sands that range in age from Tertiary to Quaternary and include some modern deposits. Relative ages of the major depositional events during the Cenozoic are well documented for coastal basins in Australia (McKellar, 1975; Roy, 1999; Roy and others, 2000; Roy and Whitehouse, 2003; Hou and others, 2006, 2008, 2011), Brazil (Leonardos, 1974; Dillenburg and others, 2004), and the southeastern United States (MacNeil, 1950; Winkler and Howard, 1977; Carpenter and Carpenter, 1991; Force, 1991). Deposits representing Pliocene transgressive-regressive events are documented in the southeastern United States and in the Perth and Murray basins of Australia.

Paleostrandline deposits are often correlated to regional sea level events. Sea level was lower than the present level during the majority of the Quaternary (fig. 55 of Force, 1991). Reductions in sea level during the Pleistocene are commonly linked to ice ages (Chappell and Shackleton, 1986). Lowering of sea level (regression) is thought to enhance erosion inland and may be accompanied by erosion of the upper parts of shores, which is the zone most often enriched in heavy minerals (Force, 1991). As a result, regression should promote heavy-mineral deposition on continental shelves (Grosz, 1987).
Pliocene transgression has been linked to heavy-mineral deposition in coastal basins across the globe, common to basins as far apart as the southeastern United States and Australia. Rises in sea level (transgression) during the Pliocene have been attributed to glacial melting and warmer climate. Haq and others (1987) suggest that sea level in the Pliocene was about $60 \mathrm{~m}$ higher than present.

High stands of local sea level can be represented by distinct terraces, which are composed of shoreline and associated facies. Many parts of the terrace or strandline systems can contain heavy minerals (Baxter, 1977; Force and others, 1982; Roy and Whitehouse, 2003; Hou and others, 2008). A coastal sedimentary basin can contain many strandline complexes, each due to separate major changes in sea level. The paleostrandlines represent intermittent transgressions and regressions that can encompass millions of years. For example, the Eucla basin of southern Australia contains dozens of strandline systems that in total span roughly 50 million years of basin history (from the Paleocene to the Quaternary) (Hou and Warland, 2005; Hou and others, 2006, 2008, 2011).

As just described, the mineralizing processes in these deposits are closely linked to transgressions and regressions of the sea, which can oscillate across a coastal basin for tens of millions of years. As an example, studies of the Cenozoic Eucla basin in southern Australia by Hou and others (2008) interpret multiple strandlines representing major depositional events in the basin during the Paleocene-early Miocene, middle to late Eocene, Oligocene-early Miocene, middle Miocene-early Pliocene and Pliocene-Quaternary. Thus, the Eucla basin experienced episodic deposition of heavy minerals for at least 50 million years (Hou and others, 2006, 2008, 2011). In the southeastern United States, heavy-mineral sands of Pliocene, Pleistocene, and Holocene age are well documented, but the continuity of deposition is not known. Cycles of major sea level fluctuations (transgressions-regressions) have intervals of millions of years, but much of the time a basin is adjusting to stillstand conditions.

Because heavy-mineral deposits are most likely to be eroded and destroyed in coastal environments and preserved only rarely, time spans of continuous heavy-mineral deposition are difficult to determine. That is, more time is missing from the sedimentation record than is represented in a sedimentary basin.

Optically stimulated luminescence has been used to date separate sand dune complexes. Lees (2006) used this technique to identify eight separate episodes of dune formation in the Great Sandy region of southern Queensland, Australia; the eight episodes encompass dune emplacements from 730,000 years ago to 500 years ago.

\section{Relations to Structures}

Geologic models of heavy-mineral deposits in coastal settings, particularly the older deposit models, commonly state that the genesis of this deposit type requires a stable tectonic 
environment. However, recent studies have linked faulting to the distribution of heavy-mineral sedimentation within a basin. For example, Roy and others (2000) and Roy and Whitehouse (2003) suggest that in the Murray basin of southeastern Australia, the distribution of heavy-mineral sands was influenced by growth faults, which overlie tilted up-faulted blocks in the basin. Hou and others (2008) suggest that development of the heavy-mineral sands deposits in the Eucla basin of southern Australia was assisted by progressive tilting of the crustal platform beneath the basin. Winkler and Howard (1977) concluded that shorelines of the southern Atlantic Coastal Plain of the United States were deformed during the Pliocene to Pleistocene, which coincided with heavy-mineral deposition in the coastal basins.

\section{Relations to Igneous Rocks}

Igneous rocks are significant sources of the heavy minerals that are ultimately deposited in coastal environments. Proposed igneous sources of the heavy minerals must in particular account for ilmenite and rutile, the most abundant of the economic heavy minerals in heavy-mineral sands.

Force (1991) provides a detailed discussion of the igneous rocks that are most enriched in $\mathrm{TiO}_{2}$ and contain an abundance of Ti oxide minerals. Force (1991) describes several magmatic rock associations as potential sources of ilmenite or rutile, such as anorthosite-ferrodiorite massifs and associated contact-metasomatic rutile deposits; alkaline igneous complexes, particularly pyroxenite units in these complexes; some granitoid rocks; some basaltic rocks; layered mafic intrusions; and kimberlites.

In southern India, charnockites, or orthopyroxene-bearing granites, are commonly considered to be the inland sources for the heavy minerals found in the beach placers (Ali and others, 2001; Panda and others, 2003; Angusamy and others, 2004). In the Orissa district, central eastern coast of India, carbonatites and granites are suggested by Chadhuri and Newesely (1993) as the probable sources of monazite within the beach placers.

\section{Relations to Sedimentary Rocks}

Sedimentary rocks can be intermediate hosts of the heavy minerals that are later deposited in heavy-mineral sands. Sedimentary rocks in coastal regions can contain enrichments in heavy minerals derived from erosion of older igneous and metamorphic rocks. Erosion of the sedimentary rocks ("intermediate host rocks") by fluvial processes, storms, waves, and currents along the coast can liberate the detrital heavy minerals from the consolidated sedimentary rocks; in this way the heavy minerals are remobilized and redeposited, this time in coastal sands. Examples of this type of relationship are described for the Murray basin of southern Australia (Roy and others, 2000; Roy and Whitehouse, 2003), the northern part of the Perth basin in Western Australia (Shepherd, 1990), the central coast of Brazil (Leonardos, 1974), and southern India (Ali and others, 2001).

\section{Relations to Metamorphic Rocks}

High-grade metamorphic rocks are considered the predominant original source of the titanium oxide minerals found in heavy-mineral sands (Force, 1991). Many studies implicate inland complexes of high-grade metamorphic rocks as the primary source of the heavy minerals deposited in a particular coastal basin. Igneous rocks are commonly associated and interspersed with the metamorphic rocks, but igneous rocks are typically considered subordinate sources of heavy minerals in comparison to metamorphic rocks.

As explained by Force (1976) and Goldsmith and Force (1978), titanium substitutes into silicate minerals (sphene, biotite, and hornblende) at lower metamorphic grades, but it transfers to titanium oxide minerals (ilmenite, rutile) at progressively higher metamorphic grades. This partitioning of titanium between silicate and oxide phases also depends on variables of rock composition (Force, 1976). Coastal sands that are rich in ilmenite and rutile are commonly associated with a hinterland composed of high-grade metamorphic rocks. Thus, because of the common regional association of heavy-mineral sands with high-grade metamorphic rocks and the strong relation between metamorphic grade and titanium mineralogy, rocks of sillimanite and higher metamorphic grade are considered the principal source of ilmenite and rutile in coastal sands.

In addition to the titanium oxide minerals, most of the other heavy minerals in the heavy mineral suite are those typical of metamorphic rocks. For example, in addition to ilmenite and rutile, common heavy minerals in coastal sands are garnets, staurolite, monazite, xenotime, and kyanite or sillimanite. These minerals indicate intermediate to high grade (amphibolite to granulite) metamorphic facies.

In the southeastern United States, from Virginia to Florida, ilmenite is ubiquitous in Pliocene and younger heavymineral sands of the Atlantic Coastal Plain. The source of this ilmenite and the associated heavy minerals has been attributed to an extensive area of sillimanite-grade metamorphism within the southern Blue Ridge and inner Piedmont regions that lies west of the coastal plain (Force, 1976).

In southern India, heavy minerals in the coastal sands are often attributed to granitic gneisses, charnockites, and khondalites (Ali and others, 2001; Panda and others, 2003). Khondalite is a regional rock name that refers to quartzfeldspar-sillimanite gneiss with graphite, garnet, and biotite, with or without cordierite. 


\section{Physical Description of Deposit}

\section{Dimensions in Plan View}

Deposits of heavy-mineral sands in coastal settings can be extensive. In terms of aerial extent, heavy-mineral sands can form some of the largest orebodies of all mineral deposit types. The large footprints of this deposit type are logical because they represent shorelines that extend for many kilometers.

Individual bodies of heavy mineral-rich sands are typically $1 \mathrm{~km}$ wide and more than $5 \mathrm{~km}$ long (Force, 1991). However, stating a typical deposit size is somewhat misleading because single deposits are generally developed as part of a district of similar deposits. Many heavy-mineral sands districts extend for more than $10 \mathrm{~km}$, encompassing several individual deposits. Heavy minerals deposits in a basin lie discontinuously along the strike of a strandline and as stratigraphically stacked deposits that represent different sea-level events through time. An example of multiple, economic heavymineral-sands deposits in a single district is the Eneabba mining district in the northern part of the Perth basin of coastal Western Australia (Geoscience Australia, 2012). An example of multiple heavy-mineral deposits aligned along the strike of a paleostrandline system is the 19 known Pliocene deposits within the upper coastal plain of Virginia and North Carolina (Carpenter and Carpenter, 1991).

Some examples of the reported dimensions of heavymineral sands deposits are as follows:

- South Australia, Eucla basin: The Jacinth deposit is approximately $900 \mathrm{~m}$ wide by $5 \mathrm{~km}$ long (Iluka Resources, 2013a).

- New South Wales, Australia, Murray basin: The longest composite deposit in the active mining district is approximately $14.5 \mathrm{~km}$ long; individual deposits are as much as $130 \mathrm{~m}$ wide (Iluka Resources, 2013a).

- Western Australia, northern part of the Perth basin: The Atlas deposit is about $7 \mathrm{~km}$ long and as much as $400 \mathrm{~m}$ wide (Image Resources NL, 2013).

- Western Australia, southeastern part of the Perth basin: An aeolian deposit of zircon and leucoxenerich mineral sands covers about $14 \mathrm{~km}^{2}$ (MZI Resources Limited, 2013).

- Southeastern India, along the Bay of Bengal, about $15 \mathrm{~km}$ southeast of Srikakulam, in the Andhra Pradesh province: The Srikurmam heavy-mineralsands deposit covers an area of $7.2 \mathrm{~km}^{2}$ within the shoreline area (Trimex Industries, 2013).

- Coastline of the State of Odisha, India: An 18-km long deposit of heavy-mineral-rich beach sands and sand dunes lies between the Rushikulya River and the town of Gopalpur; it is referred to as the "Chhatrapur Mineral Sands Deposit."

- Senegal, beginning about $50 \mathrm{~km}$ northeast of Dakar: Mineral Deposits Limited indicates that they will commence mining of their Grande Côte heavymineral sands deposit in late 2013 (Mineral Deposits Limited, 2013). The permitted mine project area is an active, mobile dune field that is in total approximately $100 \mathrm{~km}$ long and $4 \mathrm{~km}$ wide.

- Sri Lanka, northeastern coast: Heavy mineral-rich beach sands extend along the shore about $8 \mathrm{~km}$ from Asirimate to Kokkilai and extend inland from the ocean about $370 \mathrm{~m}$ (Lanka Minerals Sands Limited, 2013).

- Ukraine, Kirovohrad oblast: The Birzulivske heavymineral sands deposit covers an area $5.5 \mathrm{~km}$ long by $2.5 \mathrm{~km}$ wide (Velta LLC, 2013).

- Ukraine, Dnipropetrovsk oblast: The Volchanske heavy-mineral sands deposit is more than $20 \mathrm{~km}$ long by $1 \mathrm{~km}$ wide.

- United States, north-central Florida: The Trail Ridge deposit is a Pliocene aeolian dune complex that contains ore-grade heavy-mineral content for a length of at least $29 \mathrm{~km}$; its average width is about $2 \mathrm{~km}$ (Force and Rich, 1989; Force, 1991).

\section{Vertical Extent}

Although they can be very large in acreage, economic deposits of heavy-mineral sands are not thick. Reported thicknesses of economic deposits range from 3 to $45 \mathrm{~m}$.

\section{Form and Shape}

In plan view, deposits of heavy-mineral sands are elongate, oriented roughly parallel with the strike of the paleoshoreline for fossil deposits. In cross section, the deposits have convex lens-shaped profiles, similar in cross-section form to channel deposits of fluvial systems. Orebodies are lensshaped packages of heavy-mineral-rich sediments that total as much as tens of meters in thickness. Along the length of the strandlines, these lens-shaped ores are stacked and offset in the sedimentary stratigraphy, separated by intervals with low heavy-mineral content (see Geoscience Australia, 2012).

Terraces associated with this deposit type most likely represent major sea level events of paleostrandlines rather than faulting or other structural features. Terraces form during local high stands of the sea, and are now manifested as ridges that are as much as tens of meters high and located inland by as much as several tens of kilometers. Multiple sets of shoreline terraces are documented in the southeastern United States 
(Force, 1991) and Australia (Geoscience Australia, 2012). Each terrace level is interpreted to represent a major transgression event, which can be associated with heavy mineral deposition (Baxter, 1977).

Topographic highs in the coastal plain can represent fossil barrier islands, backshore berms, or sand dunes (fig. 3). An example of a prominent ridge formed by sand dunes is Trail Ridge, a Pliocene dune complex in north-central Florida. Trail Ridge lies $65 \mathrm{~km}$ inland from the ocean in northern Florida and forms a ridge $75 \mathrm{~m}$ above present sea level at its northern end. Trail Ridge has been a source of heavy mineral production since 1949.

Heavy-mineral sands are water- and wind-deposited sediments and, as such, in their newly deposited form the deposits are finely laminated. However, the effects of bioturbation or in-place weathering after deposition can disrupt or obliterate the laminations.

\section{Host Rocks}

Heavy-mineral-sands deposits are unconsolidated to weakly consolidated layers of sediments, and they are thus generally not hosted in bedrock. As a result, these deposits (sediments) are relatively easy to excavate and likewise easy to disaggregate for mineral separation, which greatly reduces the cost of mining and processing these deposits.

Minor production of heavy minerals has occurred in the past from sandstones that are particularly rich in heavy minerals (Force, 1991). Presently, there are no active operations that recover heavy minerals from well-lithified sandstone.

\section{Geophysical Characteristics}

\section{Magnetic Signature}

Magnetic anomalies highlight lateral contrasts in rock magnetic minerals, such as magnetite, titanomagnetite, maghemite, and hematite, integrated over depth. If those or other magnetic minerals are present within a heavy mineral assemblage, they may generate a measurable anomaly, depending specifically on material properties and quantity of those materials. Whereas magnetite, titanomagnetite, and other magnetic minerals are typically found only in trace amounts in placer deposits (partly due to oxidation and other processes that alter magnetite), other minerals such as ilmenite, which has weaker magnetic properties, might contribute to magnetic anomalies if quantities are abundant enough.

Early efforts to use magnetic surveys in the exploration for heavy-mineral placer deposits found that aeromagnetic surveys were less useful for delineation of heavy-mineral concentrations than for characterization of regional and local bedrock types (Henderson and others, 1966; Wynn and others, 1985; Light and others, 1987). For example, Bronshteyn and Karpova (1969) observed that placer deposits in the Kolyma
River basin of eastern Russia were commonly located within a few hundred meters of linear aeromagnetic anomalies, leading them to infer that those anomalies may have delineated source rocks.

More recent high-resolution magnetic surveys, with the sensor maintained closer to potential sources, have had good success in delineating heavy-mineral concentrations. Peterson and others (1986) used ground magnetic surveys to image heavy-mineral concentrations containing ilmenite and to trace magnetite (along with other nonmagnetic minerals) along the Oregon coast; associated anomalies were as high as 25-125 nanotesla (nT). Teakle and Mudge (2003) conducted low-altitude (less than $50 \mathrm{~m}$ ) airborne surveys using cropduster airplanes to image heavy-mineral concentrations near Mindarie, South Australia. Surveys required a relatively high data collection rate (10 hertz for a sample spacing of $5 \mathrm{~m}$ ), but high-pass filtered data showed distinct anomalies of $1 \mathrm{nT}$ amplitude or less. Using shipboard surveys, Siddiquie and others (1984) observed magnetic anomalies that likely represent placer deposits rich in ilmenite and magnetite in offshore Maharashtra, western India. Shah and others (2012) observed 5-10 nT magnetic anomalies in various locales of Chesapeake Bay, Maryland, and Shah and Harris (2012) observed similar anomalies in inlets near Charleston, South Carolina, both of which likely reflect accumulations of heavy minerals.

The likelihood of success from magnetic methods can be enhanced through laboratory studies of magnetic mineralogy. Force and others (2001) and Shah and others (2012) determined a likely contribution of remanent magnetization to observed anomalies (through consideration of the Koenesberger or Q-ratio), which indicates the importance of ferromagnetic minerals such as magnetite or maghemite. Where such minerals are present, even in trace amounts, their contribution to magnetic anomalies may be considerable and, in general, the magnetic response of heavy-mineral concentrations can vary widely from one region to another. Furthermore, such minerals may provide a greater contribution to the magnetic signature than other minerals such as ilmenite which, although considered magnetic, typically has a lower magnetic susceptibility and cannot support remanent magnetization. Thus, ilmenite-rich samples in Chesapeake Bay, Maryland, may exhibit a magnetic signature while others in the southeastern United States may not (Wynn and others, 1985; Shah and others, 2012).

Additional information can be gleaned from laboratory geophysical studies. Analyses of samples from heavy mineral deposits have shown correspondences between grain size and sample magnetic properties. Booth and others (2005) observed correspondences between magnetic properties and particle size, but quantitative relations differed for rivers versus estuarine and marine environments. Badesab and others (2012) observed an association between higher magnetic susceptibilities and coarser magnetic grain size. 


\section{Gravity Signature}

Gravity surveys are not typically used to delineate placer deposits but may assist characterization of surrounding geologic features. Gravity anomalies measure lateral contrasts in rock densities integrated over depth. Heavy-mineral-sediment concentrations should by definition be associated with a local density contrast. For example, for a 10 percent concentrate of heavy minerals having an average density of 4.5 gram per cubic centimeter $\left(\mathrm{g} / \mathrm{cm}^{3}\right)$ and background sediments, such as quartz, with a bulk density of $2.6 \mathrm{~g} / \mathrm{cm}^{3}$, the associated density contrast would be $1.9 \mathrm{~g} / \mathrm{cm}^{3}$. Such density contrasts are commonly measured for bodies that are several hundred meters thick and wide. Placer deposits are often thinner, but basic calculations show that a body close to Earth's surface that is less than $100 \mathrm{~m}$ thick would produce an anomaly of about 0.7 milligals (mgal). Such an anomaly is small but measurable with modern instruments. However, the lateral extent of heavy-mineral concentrations can be limited or quite variable. Because a single ground gravity measurement typically takes several minutes, surveys to delineate heavy-mineral concentrations are likely to be very time-consuming and labor-intensive compared to other approaches such as magnetic and radiometric methods. Additionally, it may be difficult to distinguish anomalies attributable to placer sources from those attributable to deeper or shallower density variations.

\section{Electrical Signature}

Electrical methods measure differences in rock conductivity, such that different methods address properties at different scales. The use of electrical methods to delineate heavymineral sands has been explored most fully through the use of induced polarity (IP), which uses time-varying currents to measure how well charges are retained. Robson and Sampath (1977) found a strong IP response to fluvial ilmenite concentrates near Jerusalem Creek, New South Wales, Australia, but Lawton and Hochstein (1980) did not observe a laboratory IP response to New Zealand titanomagnetite beach and dune sands collected from various beaches of New Zealand's North Island. Wynn and others (1985) and Wynn (1988) reported success in the marine environment, and they attributed the source of chargeability anomalies primarily to ilmenite, and to a lesser degree to leucoxene. These efforts included development of a marine IP system, which uses a towed streamer designed to maintain contact with the seafloor during measurements in order to measure submarine resistivity and chargeability variations.

\section{Radiometric Signature}

Radiometric methods measure instances of natural gamma radiation and use the associated energy spectra to calculated relative amounts of $\mathrm{K}, \mathrm{U}$, and $\mathrm{Th}$. These measurements typically represent rocks within about $1 \mathrm{~m}$ of Earth's surface.
Although gamma particles may be emitted from deeper rocks, scattering against overlying and surrounding rock prevents most gamma particles from reaching the surface and thus an instrument sensor.

Several components of heavy-mineral concentrates can generate a radiometric anomaly. The most prominent is monazite, which is apparent as elevated Th in spectral data (Force and others, 1982; Grosz and others, 1989, 1992; Grosz and Schruben, 1994). Radiometric Th anomalies may be of particular interest because of the potential of monazite to contain REE. Zircons may also generate Th and possibly $\mathrm{U}$ anomalies. Minerals observed outside of heavy mineral assemblages, such as K-feldspar and micas, can also contribute to total-count surveys, but these appear as K highs in the gamma spectra. Similarly, other U-rich phosphates will generate radiometric anomalies, and although they are often of economic interest, they are rarely found in placer deposits (Force and others, 1982; Grosz and others, 1989).

Radiometric methods especially have been used in the southeastern United States for the detection of heavy-mineral concentrations. However, whereas anomalies have indicated the presence of such deposits, many are not of economic interest because of grain size considerations (Force and others, 1982; Grosz and others, 1989). Conversely, heavy-mineral concentrations containing limited amounts of monazite, or those buried several meters below Earth's surface, are unlikely to generate a corresponding radiometric anomaly because signatures will be too weak (for example, Grosz and Schruben, 1994).

\section{Remote Sensing}

Identification and characterization of rocks and minerals by using spectroscopy became well established with the introduction of modern ground-based and airborne spectrometers in the late 20th century (Clark and others, 1990; Green and others, 1990; Salisbury and others, 1991; Cocks and others, 1998). By using high-resolution laboratory and imaging spectrometers that cover several spectral regions, a subset of this information can be used to identify mineral constituents within heavy-mineral sands.

Laboratory spectra of the minerals related to heavymineral sands show a wide range of spectral features in the visible (VIS) to mid-infrared (MIR) region of the electromagnetic spectrum (Hunt, 1982; Salisbury and others, 1991; Clark and others, 2007). Heavy-mineral sands contain 90-99 percent light minerals, which generally include large concentrations of quartz and clay minerals. Quartz sand spectra are transparent in the VIS to near-infrared (NIR) range, but diagnostic features caused by asymmetric stretch fundamentals, bending modes, and symmetric stretch fundamentals occur in the MIR region (7.0-25.0 micrometers $(\mu \mathrm{m})$ ) of the electromagnetic spectrum (fig. 16) (Salisbury and others, 1991; Clark, 1999). Clay vibrational features are typically seen at approximately $2.2 \mu \mathrm{m}$ and are generally associated with kaolinite in heavy-mineral 


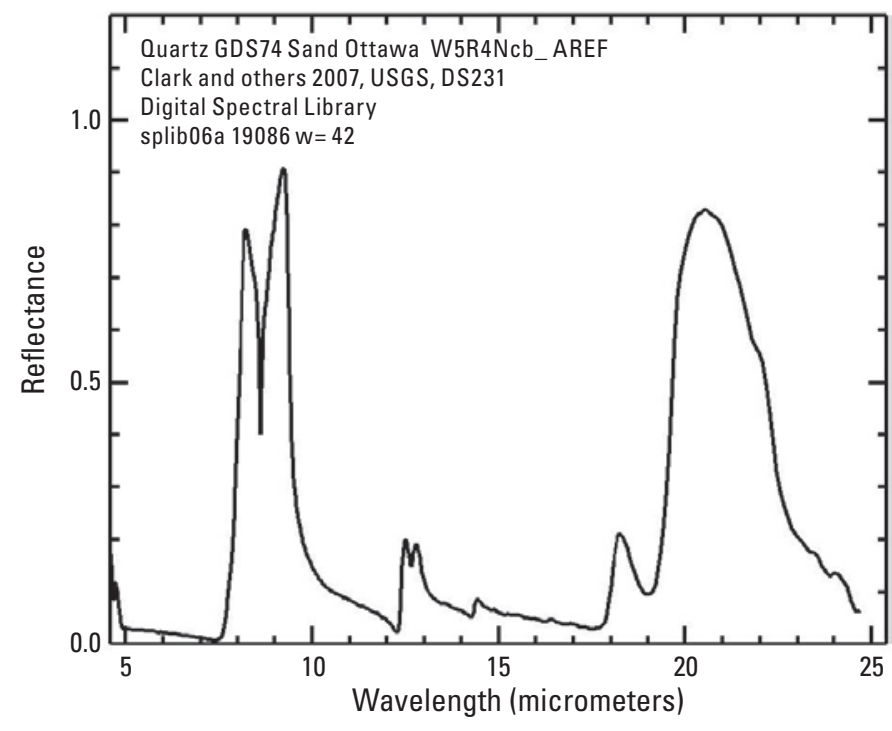

Figure 16. Quartz sand sample GDS74 showing the mid-infrared region of the spectrum (Clark and others, 2007).

sands. Other less abundant light minerals such as amphiboles, biotite, and muscovite also have $\mathrm{Mg}-\mathrm{OH}$ or $\mathrm{Al}-\mathrm{OH}$ vibrational absorption features in the $2.0 \mu \mathrm{m}$ region; these minerals have different diagnostic spectral bands that allow the identification of each mineral within the spectrum.

Approximately 80 percent of the heavy-mineral suite is typically ilmenite, rutile, iron-oxide minerals, and zircon, with lesser amounts of leucoxene, monazite, garnets, sillimanite, and staurolite. The titanium-bearing minerals in the heavy fraction of the mineral sands, such as ilmenite, rutile, and leucoxene, all lack definitive diagnostic features in the VIS to NIR. The $\mathrm{Fe}^{2+}$ ion in ilmenite causes a broad, weak absorption feature near $0.5 \mu \mathrm{m}$, but the overall low reflectance level of ilmenite can make identification of this band difficult when ilmenite is mixed with other minerals in sand (Clark, 1999). The Ti-O stretching bands in the MIR are diagnostic and can be used to identify the Ti-bearing minerals. Spectra of zircon and monazite show fine structure in the VIS to NIR that are caused by crystal field f-f transitions of REE ions present in the minerals (fig. 17). These sharp spectral bands allow accurate identification of the minerals when they are present in large concentrations and can also help identify the REEs within their structure. The remaining heavy minerals, mainly garnet, sillimanite, and staurolite, are aluminum silicates that have their fundamental absorptions in the MIR and lack diagnostic features in the NIR (Salisbury and others, 1991; Clark and others, 2007). Iron-oxide minerals are also common in heavy minerals sands and generally originate from iron that is leached from ilmenite (Force, 1991; Paine, 2005). Iron-oxide has a broad absorption band near $1.0 \mu \mathrm{m}$ caused by an $\mathrm{Fe}^{3+}$ electron transition.

Diagnostic spectral features makes identification of each of these minerals possible with laboratory and imaging spectroscopy; however, there are significant challenges when trying to identify these minerals in poorly sorted sediment. Current VIS to NIR imaging spectrometers generally cover the $0.35-2.5-\mu \mathrm{m}$ spectral range. The VIS to NIR spectra of heavy-mineral sands possess spectral features within the same intervals as clays (in the $2.0 \mu \mathrm{m}$ region) and $\mathrm{Fe}^{3+}$ in iron oxides (in the $1.0 \mu \mathrm{m}$ region) (Clark, 1999). Minerals such as zircon and monazite, which do have unique spectral features in the shorter wavelengths, occur in concentrations that are very difficult to detect by using airborne or spaceborne remote sensing.

Quartz sand and titanium minerals lack sufficient diagnostic absorption features in the VIS to NIR, but their respective $\mathrm{Si}-\mathrm{O}$ and Ti-O fundamental stretches within the MIR wavelength region can be used for identification (Salisbury and others, 1991; Clark and others, 2007). Thermal sensors can detect these absorption features, but mixtures of these minerals as found in natural deposits, also limit the utility of a thermal sensor. For instance, quartz sand is the most abundant mineral in most beach sediments, and its $\mathrm{Si}-\mathrm{O}-\mathrm{Si}$ asymmetric stretch fundamental band near $9.0 \mu \mathrm{m}$ is so strong that it is impossible to detect the weaker features of ilmenite, rutile, or leucoxene.

Indirect detection of heavy-mineral sands using nighttime thermal-infrared sensors combined with digital elevation model (DEM) or airborne electromagnetic (AEM) data may be possible (Fabris, 2002; Hou and others, 2011). Thermal inertia can differ for different materials on the basis of their soil or rock properties (their ability to store heat), water content, porosity, and density. Fabris (2002) suggests that the thermal inertia of water and materials associated with heavy-mineral sands may be used to identify subsurface paleochannels and strandlines.

Laboratory and imaging spectroscopy have become effective tools for mineral exploration, but additional investigations are needed to determine the effectiveness of using this technology to identify the minerals of interest related to heavymineral sands. In particular, additional studies are needed to determine the lower detection limits of the minerals of interest within heavy beach sands and the spectral and spatial resolution needed to accurately identify their spectral bands.

\section{Hypogene Ore Characteristics}

Hypogene processes are not directly associated with the formation of heavy-mineral sands. However, igneous and high-grade metamorphic rocks are the principal sources of the economic heavy minerals that ultimately are deposited in the sands. Crystalline source rocks in the hinterland can be altered by hypogene processes, thereby affecting their mineralogical character, including their heavy-mineral composition. The formation of titanium oxide minerals, such as ilmenite and rutile, under magmatic and metamorphic conditions is discussed by Force $(1976,1991)$ and Goldsmith and Force (1978). 


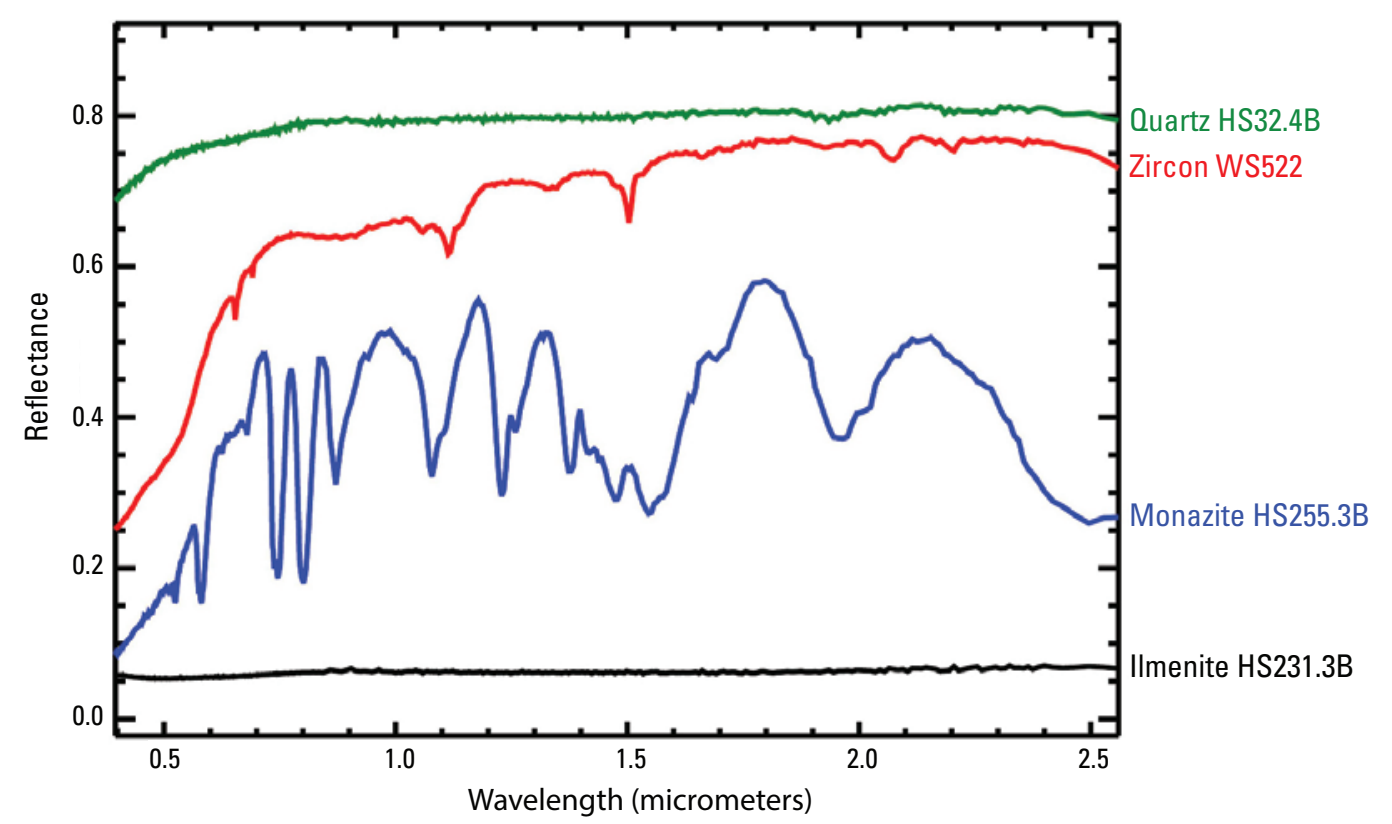

Figure 17. Quartz sand, zircon, monazite, and ilmenite spectra in the visible to near-infrared range possess both electronic and vibrational absorption features (Clark and others, 2007).

\section{Hydrothermal Alteration}

Hydrothermal processes are not related to the formation of heavy-mineral sands. In fact, hydrothermal alteration of either the heavy-mineral sands or the igneous and metamorphic source rocks that supply ilmenite and rutile would likely alter or destroy these minerals, rendering them unusable. In addition, economically productive heavy-mineral sands deposits are found most commonly on the passive margins of continents, which are regions that tend to be quiescent in terms of magmatism and associated hydrothermal processes.

\section{Supergene Ore Characteristics}

Supergene processes are not related to the formation or enrichment of heavy-mineral sands.

\section{Weathering Processes}

\section{Role of Weathering in Deposit Genesis}

Weathering processes are particularly important in the formation and concentration of heavy-mineral sands. For example, weathering at the bedrock source disaggregates the rock, reduces the mass of the rock by destroying the less stable minerals, and liberates the heavy minerals into the fluvial system as mainly monomineralic detrital grains. After deposition in sediments, weathering enhances the $\mathrm{TiO}_{2}$ content of some
Ti-oxide minerals. In particular, iron is leached from ilmenite by weathering, which thereby upgrades the $\mathrm{TiO}_{2}$ content of the ilmenite.

As detailed by Force (1991), heavy minerals weather in four general settings during the formation of heavy-mineral sands. These settings are weathering (1) of the weathered mantle that lies on igneous and metamorphic source rocks, (2) during fluvial transport, (3) within intermediate sedimentary rock hosts, and (4) following the deposition of a heavy mineral in coastal sediments.

It is well documented from studies of Quaternary marine terraces of the southeastern United States that the higher terraces are the older ones, and these older terraces contain heavymineral assemblages that are more weathered and mature (less feldspar) (Neiheisel, 1962; Force and others, 1982; Force, 1991). The most chemically stable minerals, which typically are ilmenite, rutile, zircon, sillimanite, kyanite, staurolite, and monazite, are variably weathered but mainly intact in the oldest terraces, whereas readily leached minerals such as biotite, feldspars, amphiboles, and pyroxenes are scarce or absent. Also, within a basin the $\mathrm{TiO}_{2}$ content is greater in the ilmenite from the higher (older) marine terraces, presumably owing to longer periods of weathering and loss of iron (Force and others, 1982).

Iron oxide minerals are common in heavy-mineral sands and give the sediments hues of red, yellow, and orange. Iron is mostly leached from ilmenite $\left(\mathrm{Fe}^{2+} \mathrm{TiO}_{3}\right)$ (Force, 1991; Paine, 2005).

Clays are very common components of heavy-mineral sands, composing 30 percent or more within some deposits (Carpenter and Carpenter, 1991). Clays within these deposits are informally called "slimes." One unresolved debate concerns the origin of most of the clay in heavy-mineral sands. 
Clays may be abundant because they were deposited with the sandy sediments, formed by weathering in place of minerals after sediment deposition, or were introduced to the sands after deposition.

\section{Geochemical Processes}

Most ilmenite alteration occurs after the ilmenite is deposited in sediment. During most of its transport to the coastal plain, ilmenite and other resistant, stable heavy minerals are subjected more often to mechanical forces, such as tumbling, abrasion, and rounding, rather than to chemical weathering.

Carpenter and Carpenter (1991) compared ilmenite concentrates from drill cuttings above the water table to those below the water table collected from the same drill hole. Ilmenite collected below the water table contained 53 percent $\mathrm{TiO}_{2}$ whereas ilmenite above the water table contained more than 56 percent $\mathrm{TiO}_{2}$ (Carpenter and Carpenter, 1991). The conclusion is that oxidizing conditions play a role in ilmenite alteration, perhaps a major role, which ultimately enriches ilmenite in $\mathrm{TiO}_{2}$.

In concert with the effects of groundwater, the alteration of the heavy-mineral sands can be influenced by organic matter, such as humates and associated humic acids. As explained by Force (1991), iron can go into solution during the humicacid leaching of ilmenite $\left(\mathrm{Fe}^{2+} \mathrm{TiO}_{3}\right)$, and this iron then precipitates as hydroxide phases.

\section{Rates of Reactions, Factors Controlling}

The rates of weathering reactions in heavy-mineral sands are not well studied. The heavy-mineral assemblages within the oldest marine terraces of a basin are more weathered and mature in comparison to the heavies found in younger terraces. Factors that could influence the weathering rates of heavy minerals in these deposits include the following:

- The extent of subaerial exposure of the sediments affects the durations of oxidizing conditions. Transgressions of the sea can cover underlying sediments for potentially millions of years.

- Acting in conjunction with oxidizing conditions, the leaching action of humic acid can alter ilmenite and other heavy minerals.

- Depth of the water table and the character of the groundwater influence oxidation effects and overall weathering conditions in the deposit.

- Grain size has a marked influence on reaction rates of weathering and permeability.
- The degree of compositional uniformity (versus heterogeneity) of detrital grains influences their reactivity.

- Iron hydroxide cement reduces permeability of the sediments and reactivity of individual grains.

\section{Effects of Microclimates and Macroclimates}

Climate, which is directly related to weathering, is partly a function of latitude. Force (1991) noted that Quaternary deposits of heavy-mineral sands are found only at latitudes of $35^{\circ}$ or less; this relationship may also hold true for older deposits. Climate influences the weathering processes directly, first by decomposing the rock matrix and liberating the heavy minerals. Tropical to subtropical climates in particular promote chemical weathering, which disaggregates the crystalline bedrock in the source area, the important preconcentration process in the development of placer deposits.

Macroclimates have a strong influence on the formation of heavy-mineral sand and likewise influence the weathering of these deposits. For example, major transgressions and regressions of sea level during the Quaternary have been linked to cycles of the ice ages (Chappell and Shackleton, 1986; Haq and others, 1987; Force, 1991; Roy and Whitehouse, 2003; Hou and others, 2006, 2008). These major sea level fluctuations, driven by climatic cycles, have a direct influence on the weathering regime of the heavy-mineral sands. During major transgressions earlier-deposited sands would be covered by the sea, thus reducing oxidizing conditions. During major regressions of the sea, the sediments are exposed to erosion and oxidizing conditions.

\section{Effects of Hydrologic Setting}

A variety of hydrologic settings are inherent to this deposit type, extending from bedrock source to their deposition and preservation as sediments at the coast. Hydrologic settings can proceed as follows:

1. Slopewash erosion of the weathered mantle on the surfaces of igneous and metamorphic source rocks

2. Fluvial transport of the detritus

3. Deposition in intermediate sedimentary hosts

4. Erosion of the intermediate sedimentary rocks

5. Retransport of the sedimentary rock detritus by fluvial systems

6. Deposition in coastal sediments, followed by reworking by waves, tides, longshore currents, or wind. 
Despite this complex path of transport, the majority of the chemical weathering of the heavy minerals takes place after deposition in a generally quiescent environment (Force, 1991). Many examples document ilmenite that was carried from a bedrock source for long distances by rivers - and that this ilmenite, which commonly had been carried for tens of kilometers, arrived at the mouth of rivers near the coast still looking relatively fresh (Neiheisel, 1976; Force and others, 1982). Heavy minerals thus weather primarily under the influence of groundwaters, humic acids, and other types of intrabasinal fluids, rather than during earlier fluvial transport.

\section{Geochemical Characteristics}

\section{Trace Elements and Element Associations}

Trace elements associated with heavy-mineral sands primarily include $\mathrm{Ti}, \mathrm{Hg}$, the rare earth elements (such as $\mathrm{La}$, Ce, Pr, Nd, Sm, Eu, Gd, Tb, Dy, No, Er, Tm, Yb, and Lu), Y, Th, and U. Anomalies for these elements in stream sediments have been used to evaluate the presence of heavy-mineral sands on a regional scale (for example, Grosz, 1993). These geochemical pathfinder elements reflect the composition of the potentially economic heavy minerals of this deposit type, including ilmenite, rutile, zircon $\left((\mathrm{Zr}, \mathrm{Hf}, \mathrm{U}) \mathrm{SiO}_{4}\right)$, monazite (( $\left.\mathrm{La}, \mathrm{Ce}, \mathrm{Th},) \mathrm{PO}_{4}\right)$, and xenotime $\left(\mathrm{YPO}_{4}\right)$.

Concentrations of monazite in heavy-mineral sands represent potential sources of thorium and rare earth elements. Monazite is preferentially enriched in the light rare earth elements relative to the heavy rare earth elements, as shown in figure 18 .

\section{Zoning Patterns}

Prominent geochemical zonation is not typical of heavymineral sands. Variation in chemistry at a deposit scale likely indicates the presence or absence of heavy minerals rather than geochemical gradients due to hypogene, hydrothermal, or supergene processes. Hydrothermal alteration and other forms of geochemical diffusions typical of ore deposits are not associated with heavy-mineral sands.

\section{Fluid-Inclusion Thermometry and Geochemistry}

Fluid inclusion analyses are not common in the study of heavy-mineral sands. Fluid inclusions could provide information on the source of the mineral grains, but they would not otherwise reflect the processes that formed a sand deposit.

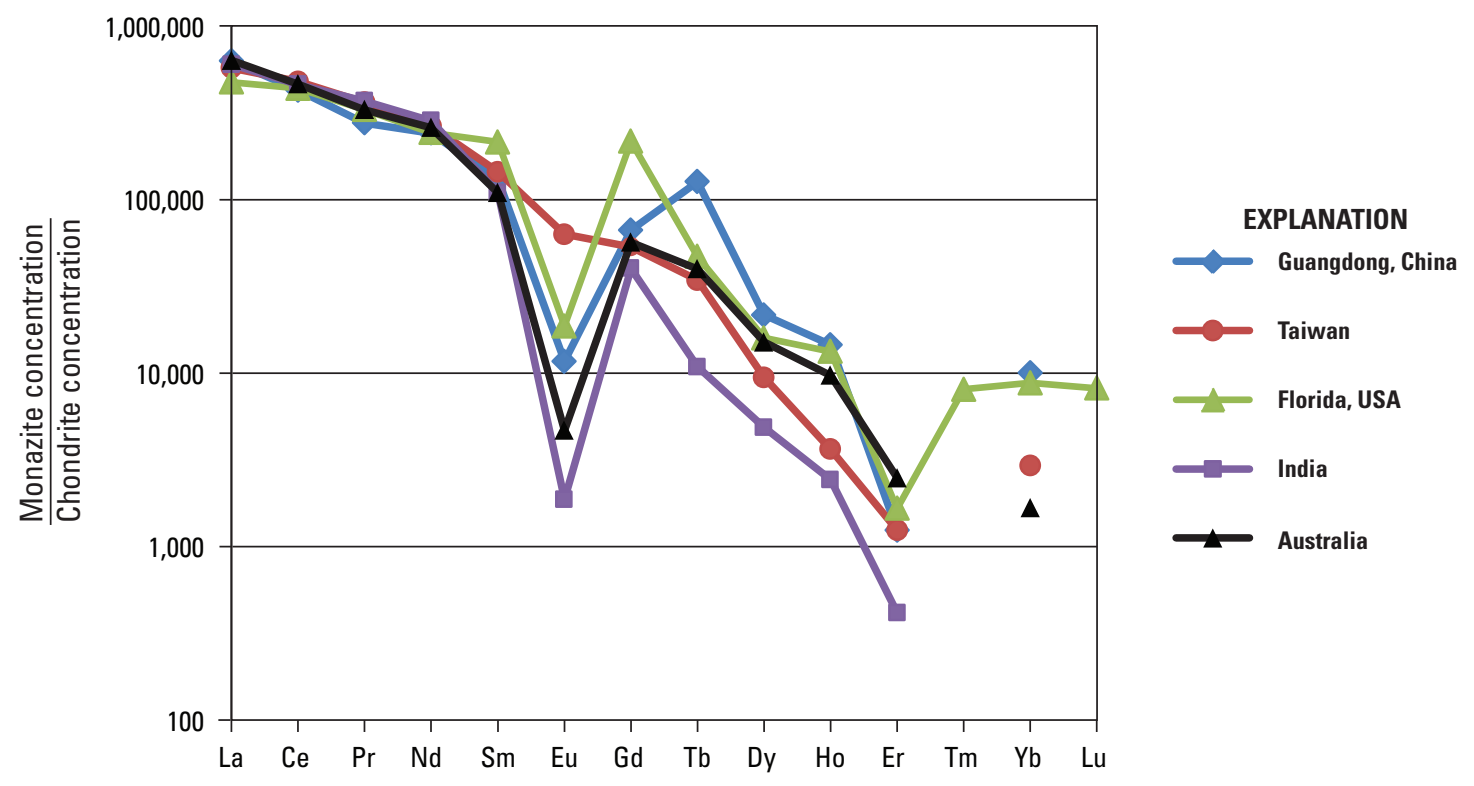

Figure 18. Chondrite-normalized plot showing the rare earth element distribution in selected monazites separated from heavy-mineral-sands deposits in four regions: Asia, North America, India, and Australia. Negative europium anomalies (the depletion in the europium concentration relative to adjacent elements samarium and gadolinium) are typical of monazite but are not universal, as displayed by the monazite sample from a heavy-mineral sand deposit in Taiwan. Monazite data from Mukherjee (2007); chondrite meteorite concentrations of the rare earth elements from Anders and Ebihara (1982). 


\section{Stable Isotope Geochemistry}

Stable isotope techniques have not been applied to the analyses of heavy-mineral sands.

\section{Radiogenic Isotope Geochemistry}

Radiogenic isotopes have been used to determine the provenance of heavy mineral grains in heavy-mineral sands. For example, detrital zircons in sediments of the Eucla basin of southern Australia revealed ages consistent with several Proterozoic and Archean zircon-bearing cratonic sources located inland (Hou and others, 2011; Reid and others, 2013).

Radiocarbon dating has been used to determine the age of Holocene individual heavy-mineral deposits (terraces) in a basin. Dillenburg and others (2004) used ${ }^{14} \mathrm{C}$ methods to date samples of shells and peat embedded in sediments to determine the age of heavy-mineral intervals in deposits at Bujuru, southern Brazil. Lees (2006) used ${ }^{14} \mathrm{C}$ methods to date multiple Holocene dune-forming events at the Newcastle Bight-Myall Lakes area in New South Wales, Australia.

\section{Petrology of Associated Igneous Rocks}

\section{Importance of Igneous Rocks to Deposit Genesis}

As described earlier, igneous rocks are a major source of the heavy minerals and other detritus that form deposits of heavy-mineral sands in coastal settings. The source of economic heavy minerals has been attributed to igneous rocks such as anorthosite-ferrodiorite massifs and associated contact-metasomatic rutile deposits; alkaline igneous complexes, including carbonatites, but particularly pyroxenite units in these complexes; granitoids; basaltic rocks; layered mafic intrusions; kimberlites; and charnockites in southern India. Igneous rocks considered as probable sources of heavy minerals are particularly those enriched in Ti-oxide minerals, such as ilmenite and rutile (Force, 1991). The rock types listed above can meet this requirement; all can contain ilmenite and rutile as well as zircon and other heavy minerals.

\section{Forms of Igneous Rocks and Rock Associations}

The igneous rocks that originally contain heavy minerals are diverse in igneous form. They also have a wide variety of associations with other rock types. However, it may be generalized that plutonic igneous rocks contribute the most detritus to a coastal basin simply because sizeable plutons, when deeply weathered, have the capacity to supply the largest volume of detritus. Nonetheless, heavy-mineral-bearing igneous rocks of all shapes and forms contribute heavy minerals to coastal sands, although in various quantities due to erosional drainage patterns and geomorphology.

\section{Mineralogy}

Igneous rocks of numerous types contribute detritus to coastal heavy-mineral sands deposits, but most relevant are those igneous rocks that contain stable, resistant heavy minerals. In particular, igneous rocks containing ilmenite, rutile, or zircon are important sources for economic sands deposits. Other igneous heavy minerals, sometimes valuable as coproducts, are garnets and monazite, which is a source of rare earth elements and thorium (table 1). The heavy minerals are disaggregated from the igneous rocks by weathering, carried with sediment by fluvial systems to the coast, and ultimately deposited with sands and silt at the coast. Thus, chemically stable, mechanically resistant heavy minerals in igneous source rocks are essential to this deposit type; these are the heavy minerals with the stability to survive the journey from bedrock to coast.

\section{Textures and Structures}

A wide variety of igneous textures are associated with heavy-mineral-bearing igneous rocks. No specific textures or structures are characteristic of the igneous source rocks for this deposit type.

\section{Grain Size}

Grain sizes of heavy-mineral-bearing igneous source rocks range widely from fine grained to very coarse grained (pegmatitic).

\section{Petrochemistry}

High $\mathrm{TiO}_{2}$ content is the principal petrochemical characteristic of the igneous source rocks associated with heavymineral-sands deposits. In mafic intrusions, much of the $\mathrm{TiO}_{2}$ is hosted in magnetite, which is of little interest in economic heavy-mineral sands. Thus, igneous rocks in which the high $\mathrm{TiO}_{2}$ content is primarily due to ilmenite or rutile are the desired rock types (Force, 1991).

\section{Trace-Element Geochemistry}

The literature on the trace-element chemistry of the relevant igneous rocks is enormous and beyond the scope of this model. 


\section{Isotope Geochemistry}

Radiogenic isotopes have been used to trace the heavy mineral assemblages in sediments to their igneous sources (Hou and others, 2011; Reid and others, 2013).

\section{Depth of Emplacement}

Heavy-mineral-bearing igneous rocks emplaced at a wide range of depths have provided heavy minerals to coastal placers. As noted earlier, plutonic rocks, which form deep in the crust, generally serve as a principal igneous host of heavy minerals owing to the large mass of igneous plutons. However, some igneous masses emplaced at or near the surface, such as mafic volcanic rocks, can locally contribute heavy minerals to heavymineral sands. Thus, igneous source rocks have not shown a direct relationship between depth of emplacement, heavymineral content, and contribution to heavy-mineral sands.

\section{Petrology of Associated Sedimentary Rocks}

\section{Importance of Sedimentary Rocks to Deposit Genesis}

Sedimentary rocks can be an intermediate host for heavy minerals that are subsequently deposited in heavy-mineral sands. Sedimentary rocks located inland or near the coastal plain can contain detrital grains of heavy minerals derived from past erosion of igneous and metamorphic rocks. A second period of erosion of these sedimentary rocks by fluvial processes or coastal storms and sea waves can remobilize the heavy minerals, which are then re-deposited in coastal sands (Leonardos, 1974; Shepherd, 1990; Roy and others, 2000; Ali and others, 2001; Roy and Whitehouse, 2003).

\section{Rock Names}

The sedimentary rock types most associated with this deposit type are sandstones and conglomerates. These sedimentary lithologies are the most likely to contain detrital grains of heavy minerals, derived from previous erosion of igneous and metamorphic rocks.

\section{Mineralogy}

Sandstones and conglomerates that serve as intermediate hosts for heavy-mineral sands are most commonly dominated by quartz sand grains, followed by silt and clays. These rocks may be cemented by calcite or silica, and secondarily by iron-oxide minerals. Less mature sandstones and conglomerates may contain grains of feldspars, micas, amphiboles, or pyroxenes, in addition to the heavy minerals typical of heavymineral sands (table 1).

\section{Textures}

Sandstones and conglomerates that are intermediate hosts of heavy-mineral sands display textures and lamination typical of fluvial deposits or water-laid (or both) coastal plain deposits. Aeolian sandstones (cross-bedded) may also act as an intermediate source of heavy minerals.

\section{Grain Size}

Grain sizes can range from fine to coarse but most typically are fine to medium.

\section{Environment of Deposition}

Heavy-mineral-bearing sedimentary rocks that serve as intermediate hosts can form in fluvial, coastal, and aeolian environments. Intermediate sandstone source rocks formed in many of the same depositional settings in which economic heavy-mineral sands are deposited.

\section{Petrology of Associated Metamorphic Rocks}

Certain varieties of metamorphic rocks, especially highgrade metamorphic rocks, are considered the primary source of the heavy minerals found in heavy-mineral sands (Force, 1991). The important role and petrologic characteristics of metamorphic rocks that contribute to the formation of heavymineral sands is discussed in this section.

\section{Importance of Metamorphic Rocks to Deposit Genesis}

As explained in an earlier section (Relations to Metamorphic Rocks), metamorphic rocks, and in particular high-grade metamorphic rocks, are the predominant source of heavy minerals in most heavy-mineral sands (Force, 1991). Rocks of sillimanite and higher metamorphic grade are considered the primary source of ilmenite and rutile, as well as garnets, staurolite, sillimanite/kyanite, and xenotime in coastal heavymineral sands (table 1).

\section{Rock Names}

The metamorphic rock types that provide heavy minerals are principally varieties of gneiss, schist, and amphibolite. When described, these types of metamorphic 
rocks are usually preceded by mineral descriptors (for example, "quartz-feldspar-sillimanite gneiss with graphite, garnet and biotite \pm cordierite," referred to in southern India as "khondalite").

\section{Mineralogy and Assemblages}

The subordinate minerals within metamorphic rocks of higher grade are those that are present in heavy-mineral sands, such as ilmenite, rutile, garnets, staurolite, monazite, xenotime, and kyanite or sillimanite. In addition to quartz, major constituents of the metamorphic rocks can be feldspars, micas, amphiboles, or pyroxenes; these minerals typically weather, alter, disintegrate, and dissolve before reaching the coast.

\section{Mineral Facies}

The heavy minerals of economic interest in heavymineral sands indicate high-grade metamorphism (amphibolite to granulite facies). For example, the source of ilmenite and the associated heavy minerals in the coastal plain of the southeastern United States has been attributed to an adjacent province of sillimanite-grade metamorphic rocks within the southern Blue Ridge and inner Piedmont regions (Force, 1976).

\section{Deformation and Textures}

As noted above, a wide variety of rocks of sillimanite and higher grade metamorphism are sources of heavy minerals for the coastal deposits. Description of the range of metamorphic deformational and textural varieties is beyond the scope of this model.

\section{Grain Size}

Grain sizes in source metamorphic rocks generally ranges from medium to coarse.

\section{Environment of Deposition}

Heavy-mineral-rich metamorphic rocks include types formed by regional metamorphism and contact metamorphism. On the scale of a basin, high-grade metamorphic rocks formed by regional metamorphism are the largest contributors of heavy minerals to coastal sands. Locally, high-grade metamorphic rocks formed by contact metamorphism can also add heavy minerals to sediments. The principal varieties of metamorphic rocks that contribute heavy minerals to heavymineral deposits, the metamorphic processes that form these parent rocks, and the important titanium oxide minerals are described in detail by Force (1991).

\section{Theory of Deposit Formation}

The basic processes involved in the formation of heavymineral sands in coastal areas are straightforward. In the hinterlands, heavy-mineral-bearing metamorphic rocks, igneous rocks, sandstones, and conglomerates weather, disaggregate, and erode, supplying detritus to fluvial systems that includes heavy minerals. Streams and rivers transport this detritus to the coast. The sediments can be ultimately deposited in a variety of coastal settings, such as deltas, the beach face (foreshore), offshore, barrier islands, or tidal lagoons, as well as the channels and floodplains of streams and rivers in the coastal plain. The newly deposited sediments are worked by the actions of waves, tides, longshore currents, and wind, which can effectively sort the mineral grains based on their size and density. As a result, the heavy dense minerals ("heavies") are sorted together, sometimes producing packages of sediments several meters thick with high concentrations of heavy minerals ( 2 to more than 10 percent heavies). The resulting deposits are commonly referred to as "heavy-mineral sands." The majority of the largest economic deposits of heavy-mineral sands embody either deposits of the foreshore, aeolian deposits (sand dunes) behind the beach, or barrier islands.

All of the steps enumerated above apply to both ancient and modern deposits of heavy-mineral sands, with minor modifications. The same processes that formed extensive deposits of heavy-mineral sands during the Tertiary and Quaternary also operate along several coasts today.

Superimposed on the general ore-forming processes are innumerable regional and local factors that can influence the development of heavy-mineral sands, such as the following:

- Wave actions presort heavy minerals that were deposited offshore by rivers. Storm events drive energetic swell action, which moves sand and heavy minerals from the offshore to the foreshore (fig. 2). Whereas waves transport the minerals onshore, mineral grains are sorted on the basis of their size and specific gravity. The heaviest, finest-grained heavy minerals are the most effectively sorted (Komar and Wang, 1984).

- Fine-grained sands mixed with heavy minerals that are brought to the foreshore (beach) can be remobilized again by winds and form heavy-mineral-bearing sand dunes positioned behind the high-tide berm of the beach (fig. 3).

- The direction and strength of coastal currents (longshore drift) and the geomorphology of the coast exert strong influences on the location of the heavymineral sands deposits (Baxter, 1977).

- Sea level fluctuations are a function of climatic changes, such as cycles of ice ages followed by ice melting (McKellar, 1975; Chappell and Shackleton, 1986; Hou and others, 2006, 2008). Rises in regional sea level (transgression) and lowering of sea level 
(regression) have strong influences on the deposition and ultimate preservation of heavy-mineral sands. During extended periods of transgression, seas can flood the mouths of rivers and thereby reduce sedimentation at the shore. At the same time, underlying sediments may become buried and preserved during transgression. During regression, erosion is enhanced inland and near the shore (Roy, 1999), potentially increasing sedimentation along the shore and offshore on the continental shelf (Grosz, 1987).

- Faulting may enhance sedimentation or control the distribution of heavy mineral deposition in a coastal basin (Roy and others, 2000; Hou and others, 2008, 2011). Ridges and troughs produced by faults and folds may serve as barriers and traps for heavy mineral accumulation within near-shore basins.

- Bedrock in the source areas must be particularly enriched in ilmenite or rutile. These minerals are the principal ore minerals in economic deposits of heavy-minerals sands.

- Most of the weathering observed in the heavy minerals is thought to have taken place after their deposition in the coastal plain, rather than at the bedrock source or during fluvial transport. In place weathering of the heavy minerals is due to groundwaters, humic acids, and other types of intrabasinal fluids. This weathering enhances the $\mathrm{TiO}_{2}$ content of ilmenite in particular; iron is leached from ilmenite during weathering, which thereby upgrades the $\mathrm{TiO}_{2}$ content of the ilmenite. Ilmenite from the older marine terraces of a basin has been shown to have a higher $\mathrm{TiO}_{2}$ content than the ilmenite in younger terraces of the same basin, presumably due to longer exposures to weathering and loss of Fe from the ilmenite with time (Force and others, 1982).

- Roy (1999) suggested that development of a mature heavy-mineral suite is enhanced by (1) relatively low rates of sediment supply, (2) long periods of erosion, (3) strong sustained wave action that moves fluxes of sand onshore and along the shore, and (4) fluctuations in sea levels, mainly sea transgressions. The combined effects of these processes result in progradation, a forward building of the shoreline due to thick accumulation of sediments towards the sea.

- The principal zone of mineral sorting is the upper part of the swash zone or the upper foreshore, the highest zone reached by waves on the beach face (fig. 3; Force, 1991). The heaviest grains, which have the highest settling velocities, are deposited at the bottom of the swash zone. Coarse, low-density mineral grains are carried by backwash to the wave zone, whereas heavy minerals tend to settle and accumulate on the upper beach face.
- Fossil heavy-mineral sands deposits, after they are removed from the subaerial environment, are preserved by climate change or epirogenic movements and eustasy.

\section{Exploration and Resource Assessment Guides}

\section{Geological}

The foundation for locating deposits of heavy-mineral sands of considerable size are identification of ancient or modern coastal plains fed by streams and rivers that drain terranes where abundant high-grade metamorphic rocks or igneous rocks crop out. These rock types tend to be particularly enriched in Ti-oxide minerals, specifically ilmenite and rutile.

Economic deposits of heavy-mineral sands are those formed during the Paleogene, Neogene, or Quaternary. Heavymineral deposits of Cretaceous age or older are likely to be hosted by lithified, well cemented sandstones. Thus, restricting the assessment areas to unconsolidated Paleogene, Neogene, and Quaternary sediments deposited in coastal environments is a first-level exploration and assessment guideline.

Detailed geologic mapping that divides sedimentary units by time period, such as epoch, can benefit the search for deposits. For example, during the Pliocene many economic deposits of heavy-mineral sands formed along the cratonic margins of widely separated continents, such as in the southeastern United States (Force and others, 1989; Carpenter and Carpenter, 1991) and coastal basins in Australia (Roy and others, 2000; Roy and Whitehouse, 2003; Hou and others, 2006, 2008, 2011; Geoscience Australia, 2012). Also, within a single coastal basin, time-equivalent sedimentary units can indicate the extent of ancient strandlines and thus the possible locations of related deposits.

\section{Geochemical}

Grosz (1993) described the application of stream sediment surveys to locate deposits of heavy-mineral sands in the Mid-Atlantic Coastal Plain of the United States. His study analyzed concentrations of Ti, Hf, REE, Th, and $\mathrm{U}$ in stream sediments. These pathfinder elements were selected to detect the presence of the heavy minerals typical of this deposit type, such as ilmenite $\left(\mathrm{FeTiO}_{3}\right)$, rutile $\left(\mathrm{TiO}_{2}\right)$, zircon $((\mathrm{Zr}, \mathrm{Hf}, \mathrm{U})$ $\left.\mathrm{SiO}_{4}\right)$, monazite $\left((\mathrm{Ce}, \mathrm{La}, \mathrm{Y}, \mathrm{Th}) \mathrm{PO}_{4}\right)$, and xenotime $\left(\mathrm{YPO}_{4}\right)$. Grosz (1993) concluded that geochemical data may be used to locate deposits of heavy minerals, particularly by indicating areas in the Mid-Atlantic region that merit more detailed sampling and analyses.

The traditional style of field sampling for this deposit type involves shallow drilling by a hand auger or truckmounted rotary drill to collect unconsolidated samples of 
sediments (fig. 19). Commonly, these samples are analyzed only for their heavy-mineral content and heavy-mineral distribution; they are not routinely submitted for geochemical analyses. Several stepwise procedures are required to prepare and analyze sediment samples to determine their heavy-mineral content and identify the individual heavy minerals (Berquist, 1987; Carpenter and Carpenter, 1991). Mineral identification and quantification of the heavy-mineral suite can now utilize automated mineralogical analysis techniques (Rollinson and others, 2011; Nie and others, 2013).

\section{Geophysical}

Geophysical methods used for heavy mineral exploration include radiometric (gamma-ray spectrometry) surveys, magnetic surveys, and induced polarity surveys. These methods are discussed in detail in the previous Geophysics section.

\section{Attributes Required for Inclusion in Permissive Tracts at Various Scales}

Identifying the existence and trends of paleostrandlines is a key attribute in defining permissive areas for undiscovered deposits. Many deposits of heavy minerals, each representing time-equivalent depositional events, can exist along the length of a strandline when it is viewed locally and regionally along a coastal sedimentary basin. For example, at least 19 known heavy-mineral deposits follow Pliocene strandlines in the upper coastal plain of Virginia and North Carolina (Carpenter and Carpenter, 1991).

Permissive tracts for this deposit type, regardless of scale, may be limited only to near-surface, unconsolidated sediments deposited in coastal environments. Economic deposits of this type, regardless of their heavy-mineral content (grade), typically are exploited only if they lie within a few tens of meters of the surface. In contrast to many metallic deposits, thick cover (hundreds of meters thick) of barren or low-grade material overlying these deposits typically renders the deposit uneconomic owing to additional costs of mining and handling thick overburden.

\section{Knowledge That Enables Favorability Zonation of Permissive Tracts}

In regards to heavy-mineral deposits, patterns of mineral distribution are due to depositional processes rather than hydrothermal or magmatic gradients. At the shoreline, arrangements of sediment packages represent the interplay between fluvial systems and shoreline dynamics (waves,

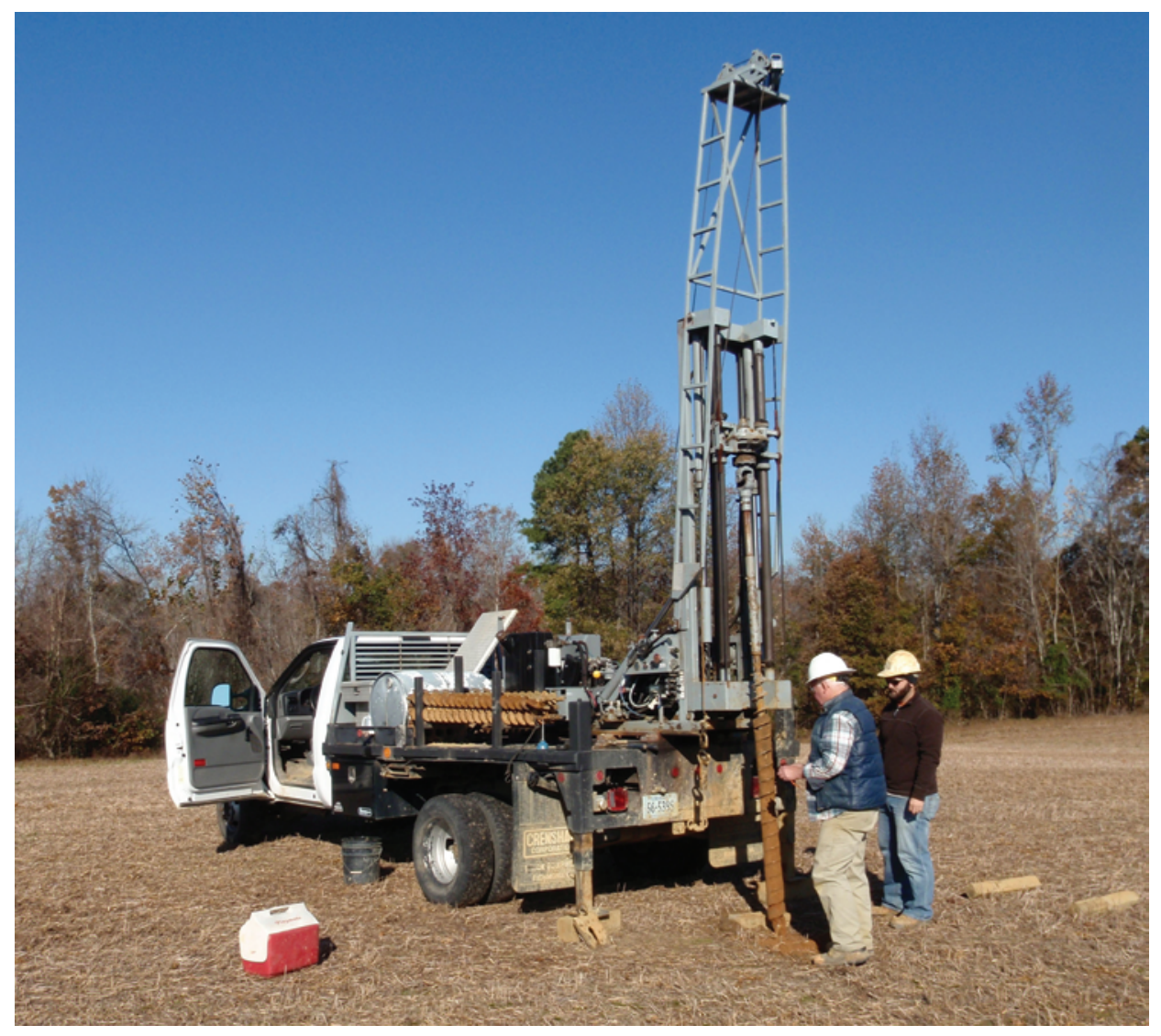

Figure 19. A truck-mounted rotary drill designed to sample unconsolidated sediments. 
long-shore currents, winds, and tides). Thus, identifying areas where streams and rivers entered the coastal area may indicate target zones most likely to contain heavy-mineral deposits.

\section{Factors Influencing Estimates of Size and Density of Undiscovered Deposits}

Heavy-mineral-sands deposits throughout a basin lie discontinuously along the strikes of many strandlines, and the sands are commonly stacked at different stratigraphic horizons that represent different sea-level events through time (transgressions and regressions). Thus, it is difficult to generalize about the typical density of these deposits in a coastal sedimentary basin; the sedimentation dynamics vary considerably from basin to basin and even within a single basin. However, it can be stated that dozens of heavy-mineral-sands deposits of substantial size can exist within a single coastal basin, as is well displayed in Australia (Geoscience Australia, 2012), southern coasts of India (Ali and others, 2001), and the southeastern United States (Carpenter and Carpenter, 1991).

Deposits of heavy-minerals sands are elongate when viewed from above, but not thick. Most deposits are less than $50 \mathrm{~m}$ thick. Because these deposits can be lengthy, their areal extent can aid in their discovery. Individual deposits of heavymineral-rich sands are typically 1 to $2 \mathrm{~km}$ wide and extend for more than $5 \mathrm{~km}$ along strike (Force, 1991). Thus, with a nearsurface footprint of 5-10 $\mathrm{km}^{2}$ or even more, individual deposits of heavy-mineral sands generally cover large areas and are thereby amenable to reconnaissance exploration techniques.

\section{Geoenvironmental Features and Effects of Mining}

\section{Effect of Weathering during the Pre-Mining Era}

Weathering, consisting of physical sorting, mechanical abrasion, and dissolution of source material minerals before or during the creation of mineral sands deposits, can influence their final mineralogical makeup (Morton and Hallsworth, 1999). Relatively unstable minerals, such as feldspar, magnetite, garnet and epidote, typically weather and disaggregate within the source sediments before they reach the coastal environment (Pirkle and others, 1974). Weathering of the deposits in place may transform some or most of the ilmenite into leucoxene by the removal of iron. Pirkle and others (1974) note that heavy-mineral-sand deposits are found only in temperate and tropical climate zones.

\section{Pre-Mining Baseline Signatures in Soil, Sediment, and Water}

Most ancient heavy-mineral sands deposits are buried under as much as 20 or more meters of overburden, and so elevated concentrations of contained trace elements, such as $\mathrm{Mg}, \mathrm{Cr}, \mathrm{V}, \mathrm{Ni}, \mathrm{Mn}$, and $\mathrm{Cu}$ from ilmenite or Th and REEs from monazite, are not likely to be incorporated into surface soil or sediment. In addition, the minerals typically found in heavy-mineral-sands deposits, such as ilmenite, monazite, zircon, rutile, staurolite, sillimanite, and kyanite, are essentially insoluble in neutral or nearly neutral-pH waters. Therefore, the major elements that compose the heavy minerals and the trace elements contained within them are unlikely to be transported in aqueous form as either dissolved or colloidal phases, either at the surface or in the subsurface. Thus, the premining baseline signatures of these buried deposits, from a geochemical perspective, are not likely to show appreciable contrast when compared to similar areas that are not underlain by economic concentrations of heavy minerals. However, the thorium within buried monazite may be detected by radiometric methods.

\section{Past and Potential Future Mining Methods and Ore Treatment}

"Wet" mining methods are commonly used with sizeable, continuous low-clay orebodies. The topsoil is removed and stockpiled; it may be used to create berms around the active mining pit. Later, the topsoil is either mixed with sand tailings and clay slimes and then returned to the mined-out void, or it is replaced on top of the mix of tailings and clay (Daniels, 2003). The pit bottom is typically below the water table, and a floating dredge with a suction cutter or bucket wheel removes the unconsolidated ore and pumps the slurry to a wet primary concentrator floating in the mine pond. The following description of ore processing is mostly from Iluka Resources (2013b).

"Dry" mining is preferred where ground conditions are hard, and orebodies are small, discontinuous, and high grade. Equipment includes scrapers, loaders, bulldozers, and trucks to excavate the ore. The ore is then screened, and material larger than 150 millimeters $(\mathrm{mm})$ is returned to the pit. The remaining ore is transferred by conveyor or as slurry through pipes to the next processing stage, the concentrator stage.

Ore, whether mined by dry or wet methods, is processed in two stages. During the wet stage, differences in particle size and density are employed to separate heavy minerals from quartz sand and clay. Subsequently, during the dry stage, differences in magnetic and electrical properties are used to separate heavy minerals from each other. In the wet stage, hydrocylones remove the clay-sized fraction, and then the underflow (heavy minerals plus quartz sand) is passed through several stages of spiral separators, where the heavy minerals are separated from the sand by using their differences in density. After separation, the clay-silt-sized fraction (slimes) is generally mixed with a flocculent/thickener, mixed with the quartz sand tailings from the spiral separators, and pumped back into the pit void.

Dry processing involves several stages of magnetic and electrostatic separation. Strong magnets remove most of the ilmenite from the feed. In the past, electromagnets were used, 
but currently (2013) permanent rare-earth drum magnets are employed to save on power costs (Tyler and Minnitt, 2004; Murty and others, 2007). The nonmagnetic minerals are then subjected to electrostatic separation that divides the nonconductive minerals (zircon, kyanite, quartz, monazite, and staurolite) from the conductive minerals (rutile and leucoxene).

Two main industrial processes are used to produce titanium dioxide from ilmenite or rutile feedstock - the sulfate process and the chloride process (Mackey, 1994). The sulfate process, developed in 1916, is the older of the two (Korneliussen and others, 2000). In the sulfate process, finely ground ilmenite (or high- $\mathrm{TiO}_{2}$ slag) (Gueguin and Cardarelli, 2007) is digested with concentrated sulfuric acid. Dust control and possible impurities in the coal used for smelting are the primary smelter concerns. After initial heating, an exothermic reaction results in the formation of a porous cake, which is then dissolved in a mixture of dilute acid and water to yield titanyl sulfate and iron sulfate (Chernet, 1999). Iron sulfate is removed as crystallized ferrous heptahydrate, also known as copperas. Environmental concerns with the sulfate process include the neutralization or regeneration of large amounts of sulfuric acid and the disposition of the large quantities of copperas. According to Mackey (1994), about 3.5 t of wastes are produced for each tonne of $\mathrm{TiO}_{2}$ product by using the sulfate process. Although copperas may be used in water treatment operations, soil enhancement, animal feed, and to reduce $\mathrm{Cr}^{+6}$ in cement, its production far outstrips demand, and much of it is either stockpiled or disposed of as landfill (Filippou and Hudon, 2009). Accessory chromium in the waste material can also be of environmental concern (Korneliussen and others, 2000).

The chloride process was developed in the $1950 \mathrm{~s}$ (Mackey, 1994). It requires higher-grade $\mathrm{TiO}_{2}$ feedstock, such as rutile from beach sands or synthetic rutile in titania slag. The feed material is calcined with coke and chlorine to form gaseous titanium tetrachloride, which is then condensed, and impurities are separated as solids. The liquid is reheated to the gaseous state and mixed with hot oxygen to form fine highpurity rutile termed white $\mathrm{TiO}_{2}$ pigment (Sahu and others, 2006). The displaced chlorine gas can be recycled and reused. This process produces only $0.2 \mathrm{t}$ of waste per tonne of $\mathrm{TiO}_{2}$ product (Mackey, 1994). As of 1992, the sulfate and chloride processes produced about equal amounts of product; since then, the chloride process has mainly supplanted the sulfate process (Joseph Gambogi, U.S. Geological Survey, oral commun., 2012). A new process developed by BHP Billiton and purchased by Altair in 1999 dispenses with the filtration step and utilizes a spray hydrolyzer to produce nanoparticles of titanium dioxide (Verhulst and others, 2003).

\section{Volume of Mine Waste and Tailings and Sizes of Operations}

Most of the material excavated or dredged from heavymineral sands deposits is sand and fine silt/slimes, which are separated from the heavy mineral suites and returned to the mine pits, placed in settling ponds, or dispersed and contoured as "replacement" dunes (Lubke and Avis, 1998). On the basis of available data for 26 deposits in the United States, Australia, and Africa, the median percentage of heavy minerals (grade) is about 4 percent. Thus, for a given volume of material mined and the heavy minerals are separated, nearly the same amount is left as waste (96 percent). A production estimate for the Cyclone mine in Australia is $10 \mathrm{Mt}$ mined per year (Diatreme Resources Limited, 2013), which would result in a mass of 9.6 Mt of waste with an approximate volume of 6.0 million cubic meters $\left(\mathrm{m}^{3}\right)$, based on a sand density of 1.6 tonnes per cubic meter $\left(\mathrm{t} / \mathrm{m}^{3}\right)$. Likewise, a production estimate for the Donald and Jackson mines in the Murray basin (Australian Atlas of Mineral Resources, Mines, and Processing Centers, 2013) of Australia is $7.5 \mathrm{Mt}$, which would result in 7.2 Mt of waste with a volume of 4.5 million $\mathrm{m}^{3}$. Total waste produced can be estimated from total mine output values recorded over the life of a mine.

The areal size of mining operations and working pits has a range, but an estimate can be made for a "typical" size. The median size for 33 wet dredging pits, the presumed active working area, obtained from aerial images for mineral sands mines around the world, was 9.7 hectares (ha; 24 acres), with median dimensions of $450 \mathrm{~m}$ long by $230 \mathrm{~m}$ wide. The actual size of each operation is considerably larger than the active pit, ranging from an estimated $2.5 \mathrm{~km} \times 1.8 \mathrm{~km}$ (Ft. Dauphin, Madagascar) to an estimated $12.4 \mathrm{~km} \times 2.3 \mathrm{~km}$ (Trail Ridge, northern Florida). The median size for eight wet mining operations estimated from aerial imagery was about 700 ha, with median dimensions of $4.2 \mathrm{~km} \times 1.8 \mathrm{~km}$.

The size of active working areas for dry mines is not as easily discerned from aerial images. The median dimensions and total size of operations obtained from aerial imagery for nine dry operations were $2.4 \mathrm{~km} \times 0.81 \mathrm{~km}$ and $275 \mathrm{ha}$.

\section{Smelter Signatures}

Literature is limited regarding smelter signatures from processing heavy-mineral-sand titanium ore. The elements $\mathrm{Mg}, \mathrm{Cr}, \mathrm{V}, \mathrm{Ni}, \mathrm{Mn}$, and $\mathrm{Cu}$ occur in ilmenite at low concentrations (Darby, 1984). Ilmenite that is beneficiated by calcining before being processed by the chloride process (described previously) may release these metals during that process. Another concern may be the metals contained in the coke used for calcining. With processing of other metals or deposit types, leaching of smelter slag can be a concern (Plumlee and Nash, 1995), but in the case of ilmenite smelting, the slag contains the $\mathrm{TiO}_{2}$ product that is then used as feedstock for further processing.

\section{Mine Waste Characteristics}

\section{Mineralogy}

The waste stream produced from the wet (primary) processing of heavy-mineral sands consists of quartz sands and slimes, which comprise silt and clay, and locally iron-coated 
kaolinite, as at the Old Hickory deposit in Virginia (Daniels and others, 2003). The dry-separation-process waste stream may include garnet, sillimanite, kyanite, or staurolite. Monazite is also separated from the ilmenite, rutile, leucoxene and zircon. In the past, monazite was partitioned into a separate product stream; for example, Lewis (1980) reported that Australia produced 10,500 $\mathrm{t}$ of monazite in 1978. Currently, most operations consider monazite an undesirable mineral, owing to thorium within the crystal structure and concerns over the storing of it as a technologically enhanced normally occurring radioactive material (TENORM). India has an interest in monazite for its thorium content, which can be used in a ${ }^{232} \mathrm{Th}^{233} \mathrm{U}$ reactor to generate electrical power (Bagla, 2005). Recent heavy-mineral-sands operations from beach and alluvial placers in India (Indian Rare Earths Limited, 2013), Malaysia (Gambogi, 2013), Sri Lanka (Lanka Mineral Sands, 2013), Thailand, Vietnam (GPM Asia, 2013), and Brazil (Indústrias Nucleares do Brasil SA (INB), 2013) report the separation and recovery of monazite as a coproduct. Indian beach placers are the principal source for ongoing production of monazite.

\section{Acid-Base Accounting}

Acid mine drainage is usually a concern when a mineral deposit is developed or mined. The reaction of sulfide minerals, mainly pyrite and pyrrhotite, in an aqueous environment with oxygen, mediated by bacteria, generates sulfuric acid (Nordstrom and Alpers, 1999; Plumlee, 1999; Plumlee and Logsdon, 1999). Pyrite is rarely if ever present in heavymineral sands, and acid mine drainage is not reported as an environmental concern for these deposits. Values of $\mathrm{pH}$ near 5.0 have been reported for freshly dewatered tailings/slimes, but this value is likely a result of the inherent acidity of soils that naturally existed before mining. The $\mathrm{pH}$ values of soil at the Old Hickory site in Virginia were reported as between 4.8 and 5.2 (Daniels and others, 2003).

\section{Geochemical Characteristics}

As discussed in the section on premining baseline signatures, heavy minerals can contain elevated levels of one or more of the elements $\mathrm{Mg}, \mathrm{Cr}, \mathrm{V}, \mathrm{Ni}, \mathrm{Mn}$, and $\mathrm{Cu}$. The ultimate fate of these elements depends on what fraction or phase of the deposit they originally resided, and what happens during processing and waste generation. Mine waste associated with heavy-mineral sands operations typically includes overburden material, sands removed from ore matrix by washing and screening, and clay that is removed by washing and screening and settled in ponds. It may also include monazite removed in the secondary processing and remixed with the sand tailings, unless the monazite is stored for future use, as has been the case in Brazil, India, Malaysia, Sri Lanka, Thailand, and Vietnam. When mixed with the sand tailings, the monazite and its contained thorium are considered below levels of concern. Overburden is stripped and removed and stored in piles, and then replaced in the pits during reclamation, and typically contains little or no contamination by trace elements. Quartz sand is replaced in mined-out pits or hydraulically dispersed and recontoured into artificial hills or dunes (Lubke and Avis, 1998).

\section{Pit Lakes}

Mining of sulfidic ore bodies by open pit (such as the Berkeley Pit, Butte, Montana) can result in a pit filled with acidic $(\mathrm{pH}<3)$, metal-laden water. Acidic pit lakes due to sulfide oxidation are not found in relation to heavy-mineralsands mining. Where wet-mining methods are used, pit lakes may remain owing to shallow water tables, or they may be backfilled as mining proceeds from one tract to another across a deposit. Dry-mined deposits may also develop pit lakes, after areas that have been excavated fill with water or are used as settling ponds for sand/slimes from concentrators. After mine closure, some pit lakes can be converted to other uses, such as water storage, recreation, or constructed wetlands for wildlife (McCullough and Lund, 2006).

Pit lake water may develop lower $\mathrm{pH}$ than surrounding groundwater. Marques and others (2012) found that the average $\mathrm{pH}$ of pit lakes related to sand mining, although not heavy minerals, in the Sepetiba basin in Brazil was 4.3, whereas average groundwater $\mathrm{pH}$ measured from well bores in the same area was 5.5. The cause of the lower $\mathrm{pH}$ in the pit lakes is ascribed to oxidation of reduced material, such as reduced clay and other forms of reduced iron, freshly exposed to the atmosphere by the mining activity. Reducing conditions in the deposit body may produce low concentrations of authigenic pyrite from iron and sulfate, which would then produce acidity upon oxidation (Marques and others, 2012). For comparison, the $\mathrm{pH}$ of unbuffered surface water equilibrated with the atmosphere is 5.6 (Lisa Stillings, U.S. Geological Survey, oral commun., 2013).

\section{Ecosystem Issues}

Any mine operation will affect the environment and ecosystem in which it is located. Although heavy-mineral-sands mine operations tend to have less effect than other mine or deposit types, potential harmful effects must be acknowledged and accounted for. Environmental effects have not always been considered in past mineral sands operations; environmental requirements and legislation have been imposed only in the past 30 years and are still not present in some parts of Africa (Tyler and Minnitt, 2004). In the past 30 years, numerous studies show the need for studies before mining (such as Lewis, 1980; Lubke and Avis, 1998; Finucane and others, 2006; Saviour, 2012) and after mining recovery (for example, Buckney and Morrison, 1992; Moll, 1992; van Aarde and others, 1996; Brewer and Whelan, 2003; Daniels, 2003; Van Etten and others, 2011) at some heavy-mineral-sand locales. 
Environmental issues of concern include effects on hydrogeology, particularly the depth to the water table, which may have increased owing to mine dewatering and water extraction required for mineral separation processes. When deep water is used for makeup water for dredging above the water table, as at the proposed Donald Mineral Sands Project, Australia (Victoria Department of Sustainability and Environment, 2006), the deep water may be more saline than nearsurface groundwater, and so the pathway for surface water to shallow groundwater is important.

Other areas of concern include (1) effects on indigenous floral and faunal species due to vegetation removal in habitat and wildlife corridors, respectively; (2) effects on wetlands, if present; (3) effects of slimes tailings or leachate from acid sulfate soils or subsoils after they are replaced in mined-out pits; (4) effects on soil biota, because seeds and microbes in stored topsoil can degrade if not used within several months; (5) the potential for effects from radiation from $\mathrm{U}$ and Th in monazite; (6) the potential in Australia to spread "dieback disease," which is caused by a fungus transportable through infected soil or roots; and (7) effects of air emissions from vehicles, machinery, and burning of coal used for drying. Vegetation after mining tends to be less diverse than the natural mix that existed beforehand, and new vegetation tends to be dominated by colonizer plants or weeds, even when seeded with the original type of vegetation (van Aarde and others, 1996; Brewer and Whelan, 2003). Soil in newly rehabilitated tracts tends to be compacted by the heavy equipment used, and this compaction reduces soil porosity, permeability, and productivity (Daniels, 2003).

Effects on the human environment include noise and light pollution, dust, increased heavy transport traffic, disruption of and increased burden on the local infrastructure, air quality, property values, and radiation concerns from monazite. Possible human health issues are discussed below.

\section{Human Health Issues}

Human health risks can be associated with exposure to dust created during mining, transport, and processing operations, and to the acids and other chemicals used in ore beneficiation, such as in the chloride or sulfate $\mathrm{TiO}_{2}$ conversion processes. More important, exposure to Th-bearing monazite dust is a serious concern for workers performing the separation processes. Monazite typically contains from 5 to 8 percent thorium and between 0.1 and 0.3 percent uranium. Monazite is commonly present in mineral sands at about only 0.5 percent, but because it is softer than the other heavy minerals, it is concentrated in dust by an estimated factor of 20:1 during the physical processes of screening, and of magnetic, electrostatic, and gravity separation (Hewson, 1997). Thorium and uranium produce ${ }^{220} \mathrm{Rn}$ (so-called "thoron") and ${ }^{222} \mathrm{Rn}$ (radon) gas from their decay chains, respectively. These two isotopes of radon emit alpha particles in their subsequent decay, and these are of concern when inhaled monazite-bearing dust becomes resident in the lungs. ${ }^{222} \mathrm{Rn}$ and its alpha dose rates have received considerable attention (Environmental Protection Agency, 2014), but the alpha activity dose rate of the much less prevalent thoron $\left({ }^{220} \mathrm{Rn}\right)$ is less widely known. However, thoron's activity rate has been shown to be approximately 0.3 to 0.5 of that of ${ }^{222} \mathrm{Rn}$, and thus thoron is also a prominent alpha emitter (Guo and others, 2005).

Other radiation hazards are external exposure to highenergy beta and gamma rays from isotopes of both the Th and $U$ decay series (Pillai, 2008). Although the presence of radioactivity and concern over external exposure in the heavysands industry has long been known, prior to the early 1980s, the hazard of internal radiation from aspirated dust was not acknowledged as it is today. Hewson (1997) reported how the estimated and measured airborne "alpha activity" in Western Australia mineral sands separation plants declined from about 2 becquerel per cubic meter $\left(\mathrm{Bq} / \mathrm{m}^{3}\right)$ prior to 1986 to about $0.2 \mathrm{~Bq} / \mathrm{m}^{3}$ by $1991-1995(\mathrm{~Bq}=$ becquerel $=1$ disintegration per second) (Hewson, 1997). Monazite is considered to be a "normally occurring radioactive material" (NORM), but if it is stored as product after its separation from other heavy-sands minerals, it is considered to be a "technologically enhanced normally occurring radioactive material" (TENORM) (Paschoa and Steinhäusler, 2013), and additional health, environmental, and safety requirements become an issue.

\section{Climate Effects on Geoenvironmental Signatures}

The study of climate effects on the environmental geology and geochemistry of mineral deposits is a relatively new field (Plumlee, 1999). In general, three factors have the most effect: temperature, humidity, and precipitation. A cold climate tends to inhibit weathering, as does a dry climate and low precipitation. A wet climate leads to a shallow water table, which tends to preclude deep weathering (Plumlee, 1999). Heavymineral-sands deposits are found in temperate and tropical climate zones, which can be either humid or arid. In hot, arid locales, tailings impoundments or pit lakes may dry and be susceptible to wind erosion.

As discussed previously in the section on premining soil and sediment signatures, the ore and gangue minerals contained in heavy-mineral-sands deposits are essentially insoluble in the surface environment, and the deposits contain essentially no sulfides; thus, element transport by hydromorphic processes is minimal, regardless of climate context.

\section{Knowledge Gaps and Future Research Directions}

A field of research that benefits the search for heavymineral sands is the development of exploration techniques, particularly techniques that can be applied at regional scales. Ideally, the techniques could also be scaled down to local scales 
to identify and delineate individual deposits that may cover less than $1 \mathrm{~km}^{2}$. Techniques that have promise to meet both goals are geophysical methods, which are described in the section Geophysical Characteristics. The application of regional geochemical surveys, using stream sediments, also requires further evaluation (Grosz, 1993).

The search for heavy-mineral sands and an understanding of their genesis are both greatly assisted by detailed geologic mapping. Detailed mapping of unconsolidated sediments is typically more difficult and time consuming than it is of lithified rock units owing to the paucity of outcrop. As a result, geologic maps of ancient coastal plains often show less detail or subdivision and only broadly defined map units. Detailed mapping of ancient coastal sedimentary units is available for some areas, but not consistently. More refined geologic mapping of coastal sedimentary units, even by epoch, benefits exploration and aids research on the origins of this deposit type.

\section{Acknowlegments}

The authors appreciate the opportunity provided by Iluka Resources to visit and become educated on their heavymineral sands deposits and operations in southern Virginia. Two noted experts in the geology of heavy-mineral sands, Baohong Hou and Carl (Rick) Berquist, provided helpful editorial reviews of the manuscript and assured its accuracy, for which we are grateful.

\section{References}

Adams, Reg, 2102, Titanium: Mining Engineering, v. 64, no. 6, p. 96-100.

Ali, M.A., Krishnan, S., and Banerjee, D.C., 2001, Beach and inland heavy mineral sand investigations and deposits in India-An overview: Exploration and Research for Atomic Minerals, v. 13, p. 1-21.

Amigo Holdings, 2013, Amigo Minerals: Amigo Holdings company Web site, accessed April 4, 2013, at http://amigo.vn/index.php?option $=$ com content\&view $=$ article\&id=61: amigo-minerals\&catid $=$ 16: companies\&Itemid $=71$.

Anders, Edward, and Ebihara, Mitsuru, 1982, Solar-system abundances of the elements: Geochimica et Cosmochimica Acta, v. 46, p. 2362-2380.

Angusamy, N., Loveson, V.J., and Rajamanickam, G. V., 2004, Zircon and ilmenite from the beach placers of southern coast of Tamil Nadu, east coast of India: Indian Journal of Marine Sciences, v. 33, no. 2, p. 138-149.
Astron Limited, 2013, Our business: Astron Limited company Web site, accessed March 25, 2013, at $h t t p: / / w w w$. astronlimited.com/our-business/index.html.

Australian Atlas of Mineral Resources, Mines, and Processing Centers, 2013, Mineral sands: Accessed May 31, 2013, at http://www.australianminesatlas.gov.au/aimr/commodity/ mineral_sands.html\#mineral_sands.

Australian Zircon NL, 2013, The WIM 150 Minerals Sand Project: Australia Zircon NL company Web site, accessed November 22, 2013, at http://www.auzircon.com.au/ wim150-project/.

Badesab, Firoz, von Dobenek, Tilo, Bryan, K.R., Müller, Hendrick, Briggs, R.M., Frederichs, Thomas, and Kwoll, Eva, 2012, Formation of magnetite-enriched zones in and offshore of a mesotidal estuarine lagoon-An environmental magnetic study of Tauranga Harbour and Bay of Plenty, New Zealand: Geochemistry, Geophysics, Geosystems, v. 13 , no. 6,20 p.

Bagla, Pallava, 2005, Rethinking nuclear power-India's homegrown thorium reactor: Science, v. 309, p. 1174-1175.

Base Resources Limited, 2013, Mineral resources: Base Resources Limited company Web site, accessed March 28, 2013, at http://www.baseresources.com.au/projects/kwalemineral-sands-project/mineral-resources/.

Baxter, J.L., 1977, Heavy mineral sand deposits of Western Australia: Geological Survey of Western Australia, Mineral Resources Bulletin 10, 148 p.

Bedinger, G.M., 2013, Titanium mineral concentrates, in Mineral commodity summaries 2013: U.S. Geological Survey, p. 174-175. Available at http://minerals.usgs.gov/minerals/ pubs/commodity/titanium/.

Behera, P., 2003, Heavy minerals in beach sands of Gopalpur and Paradeep along Orissa coastline, east coast of India: Indian Journal of Marine Sciences, v. 32, no. 2, p. 172-174.

Berquist, C.R., 1987, Minerals in high-level gravel deposits along the Fall Zone of Virginia: Virginia Minerals, v. 33, no. 4 , p. $37-40$.

Bhola, K.L., Chatterji, B.D., Dar, K.K., Mahadevan, C., Mahedvan, V., Mehta, N.R., Handi, Nagarajarao, Nanhi, H., Narayandas, G.R., Sahasrabudhe, G.H., Shirke, V.G., and Udas, G.R., 1958, A survey of uranium and thorium occurrences in India, in United Nations International Conference on the Peaceful Uses of Atomic Energy, 2d, Geneva, September 1-13, 1958 - v. 2, Survey of raw material resources, Proceedings: Geneva, United Nations Publication, p. 100-102. 
Booth, C.A., Walden, J., Neal, A., and Smith, J.P., 2005, Use of mineral magnetic concentration data as a particle size proxy - A case study using marine, estuarine and fluvial sediments in the Carmarthen Bay area, South Wales, U.K.: Science of the Total Environment, v. 347, nos. 1-3, p. 241-253.

Boswell, P.G.H., 1933, On the mineralogy of sedimentary rocks: London, Thomas Murby and Company, 393 p.

Breón, René, 1880, Séparation des minéraux microscopiques lourds: Bulletin de la Société Minéralogique de France, v. 3 , p. $45-56$.

Brewer, I.M., and Whelan, R.J., 2003, Changes in dune vegetation over 60 years in a sand-mined area of the New South Wales lower North Coast: Cunninghamia, v. 8, p. 85-92.

Bronshteyn, B.M., and Karpova, A.S., 1969, Relationship between magnetic anomalies and occurrence of gold (Kolyma river basin): International Geology Review, v. 11, no. 1, p. 21-23.

Buckney, R.T., and Morrison, D.A., 1992, Temporal trends in plant species composition on mined sand dunes in Myall Lakes National Park, Australia: Australian Journal of Ecology, v. 17, p. 254-254.

Carpenter, J.H., Detweiler, J.C., Gillson, J.L., Weichel, E.C., Jr., and Wood, J.P., 1953, Mining and concentration of ilmenite and associated minerals at Trail Ridge, Fla.: Mining Engineering, v. 5, no. 8, p. 789-795.

Carpenter, R.H., and Carpenter, S.F., 1991, Heavy mineral deposits in the Upper Coastal Plain of North Carolina and Virginia: Economic Geology, v. 86, no. 8, p. 1657-1671.

Carter, C.H., 1978, A regressive barrier and barrier-protected deposit-Depositional environments and geographic setting of the late Tertiary Cohansey Sand: Journal of Sedimentary Petrology, v. 48, no. 3, p. 933-949.

Castor, S.B., and Hedrick, J.B., 2006, Rare earth elements, in Kogel, J.E., Trivedi, N.C., Barker, J.M., and Krukowski, S.T., eds., Industrial minerals and rocks - Commodities, markets, and uses (7th ed.): Littleton, Colo., Society for Mining, Metallurgy, and Exploration, Inc. (SME), p. 769-792.

Chadhuri, J.N.B., and Newesely, H., 1993, On the REEbearing minerals in the beach placers of Puri, Orissa district: Journal of Southeast Asian Earth Sciences, v. 8, nos. 1-4, p. 287-291.

Chappell, J., and Shackleton, N.J., 1986, Oxygen isotopes and sea level: Nature, v. 324, p. 137-140.

Chernet, T., 1999, Effect of mineralogy and texture in the $\mathrm{TiO}_{2}$ pigment production process of the Tellnes ilmenite concentrate: Mineralogy and Petrology, v. 67, p. 21-32.
Clark, R.N., 1999, Spectroscopy of rocks and minerals, and principles of spectroscopy, chap. 1 in Rencz, A.N., ed., Manual of remote sensing, v. 3-Remote sensing for the earth sciences: New York, N.Y., John Wiley, p. 3-58.

Clark, R.N., King, T.V.V., Klejwa, Matthew, Swayze, G.A., and Vergo, Norma, 1990, High spectral resolution reflectance spectroscopy of minerals: Journal of Geophysical Research-Solid Earth, v. 95, issue B8, p. 12,653-12,680.

Clark, R.N., Swayze, G.A., Wise, R., Livo, E., Hoefen, T., Kokaly, R., and Sutley, S.J., 2007, USGS digital spectral library splib06a: U.S. Geological Survey Digital Data Series 231 .

Cocks, T.D., Jenssen, R., Stewart, A., Wilson, I., and Shields, T., 1998, The HyMap Airborne hyperspectral sensor-The system, calibration and performance, in Schaepman, M.E., Schlapfer, Daniel, and Itten, K.I., eds., EARSeL Workshop on Imaging Spectroscopy, 1st, 6-8 October 1998, Zurich, Switzerland, Proceedings: Paris, France, EARSeL, p. $37-43$.

Daniels, W.L., 2003, Strategies for the return of heavy mineral sands mines to productive agricultural uses, in Agioutantis, Z., ed., Conference on Sustainable Indicators in the Minerals Industry (SDIMI), 3d, May 13-17, 2003, Milos Conference Center, Milos, Greece, Proceedings.

Daniels, W.L., Orndorff, Z.W., and Schroeder, P.D., 2003, Chemical and physical properties of mineral sands mine soils in southeastern Virginia, in Joint Conference of the Billings Land Reclamation Symposium and the 2003 National Meeting of the American Society of Mining and Reclamation, Billings, Montana, June 3-6, 2003, Proceedings: p. 209-228.

Darby, D.A., 1984, Trace elements in ilmenite-A way to discriminate provenance or age in coastal sands: Geological Society of America Bulletin 95, no. 10, p. 1208-1218.

Diatreme Resources Limited, 2013, Diatreme Resources Limited company Web site, accessed May 31, 2013, at http://www.diatreme.com.au/.

Dick, A.B., 1887, On zircons and other minerals contained in sand: Nature, v. 36, p. 91-92.

Dillenburg, S.R., Tomazelli, L.J., and Barboza, E.G., 2004, Barrier evolution and placer formation at Bujuru, southern Brazil: Marine Geology, v. 203, p. 43-56.

Environmental Protection Agency, 2014, Radon (Rn): Web site accessed July 10, 2014, at http://www.epa.gov/radon/.

Fabris, A., 2002, Thermal satellite imagery-An aid to heavy mineral sand discoveries: MESA Journal, v. 24, p. 24-26. 
Ferreira, K.R.S., Sabedot, Sydney, and Sampaio, C.H., 2007, Avaliacao da presenca de monazita em concentrado de ilmenita produzido na mina do Guaju (PB): Revista da Escola de Minas (Ouro-Preto), v. 60, no. 4, p. 669-673.

Filippou, Dimitrios, and Hudon, Guillaume, 2009, Iron removal and recovery in the titanium dioxide and pigment industries: Journal of the Minerals, Metals and Materials Society, v. 61, no. 10, p. 36-42.

Finucane, Sonia, Hardman, Blair, and Harley, David, 2006, Planning for rehabilitation and closure of the Coburn Mineral Sand Mine at Shark Bay, Western Australia, in Fourie, Andy, and Tibbett, Mark, eds., International Seminar on Mine Closure, 1st, 13-15 September 2006, Perth, Australia: Australia Centre for Geomechanics, Proceedings, p. 359-370.

Force, E.R., 1976, Metamorphic source rocks of titanium placer deposits-A geochemical cycle: U.S. Geological Survey Professional Paper 959-B, 16 p.

Force, E.R., 1991, Geology of titanium-mineral deposits: Geological Society of America Special Paper 259, 112 p.

Force, E.R., and Rich, F.J., 1989, Geologic evolution of Trail Ridge eolian heavy-mineral sand and underlying peat, northern Florida: U.S. Geological Survey Professional Paper 1499, 16 p.

Force, E.R., Butler, R.F., Reynolds, R.L. and Houston, R.S., 2001, Magnetic ilmenite-hematite detritus in MesozoicTertiary placer and sandstone-hosted uranium deposits of the Rocky Mountains: Economic Geology, v. 96, no. 6, p. $1445-1453$.

Force, E.R., Grosz, A.E., Loferski, P.J., and Maybin, A.H., 1982, Aeroradioactivity maps in heavy-mineral exploration - Charleston, South Carolina, area: U.S. Geological Survey Professional Paper 1218, 19 p., 2 plates.

Frihy, O.E., 1994, Discrimination of accreted and eroded coasts using heavy mineral compositions of the Nile Delta beach sands, Egypt: Sedimentology, v. 41, p. 905-912.

Gambogi, Joseph, 2012, Titanium [advance release], in 2010 minerals yearbook: U.S. Geological Survey, p. 78.1-78.17. Available at http://minerals.usgs.gov/minerals/pubs/ commodity/titanium/.

Gambogi, Joseph, 2013, Rare earths: U.S. Geological Survey mineral commodity summaries, 2013. Available at http:// minerals.usgs.gov/minerals/pubs/commodity/rare_earths/.

Geoscience Australia, 2012, Australia's identified mineral resources 2011: Canberra, Geoscience Australia, 123 p.

Goldsmith, Richard, and Force, E.R., 1978, Distribution of rutile in metamorphic rocks and implications for placer deposits: Mineralium Deposita, v. 13, no. 3, p. 329-343.
GPM Asia, 2013, More about GPM Asia: GPM Asia company Web site, accessed April 4, 2013, at http://www.gpm.asia/.

Green, R.O., Conel, J.E., Carrere, Veronique, Bruegge, C.J., Margolis, J.S., Rast, Michael, and Hoover, Gordon, 1990, Determination of the in-flight spectral and radiometric characteristics of the airborne visible/infrared imaging spectrometer (AVIRIS), in Airborne Visible/Infrared Imaging Spectrometer (AVIRIS) Workshop, 2nd, Proceedings: JPL Publication 90-54, Pasadena, Calif., p. 15-22.

Grosz, A.E., 1987, Nature and distribution of potential heavymineral resources offshore of the Atlantic coast of the United States: Marine Mining, v. 6, p. 339-357.

Grosz, A.E., 1993, Use of geochemical surveys in Ti-Hf-REETh-U placer exploration-A Mid-Atlantic-States example, chap. R of Scott, R.W., Jr., Detra, P.S., and Berger, B.R., eds., Advances related to United States and international mineral resources-Developing frameworks and exploration technologies: U.S. Geological Survey Bulletin 2039, p. $181-188$.

Grosz, A.E., Cathcart, J.B., Macke, D.L., Knapp, M.S., Schmidt, Walter, and Scott, T.M., 1989, Geologic interpretation of the gamma-ray aeroradiometric maps of central and northern Florida: U.S. Geological Survey Professional Paper 1461, 48 p., 5 plates.

Grosz, A.E., San Juan, F.C., Jr., and Reid, J.C., 1992, Heavymineral concentrations associated with some gamma-ray aeroradiometric anomalies over Cretaceous sediments in North Carolina-Implications for locating placer mineral deposits near the Fall Zone: U.S. Geological Survey OpenFile Report 92-396, 27 p.

Grosz, A.E., and Schruben, P.G., 1994, NURE geochemical and geophysical surveys-Defining prospective terranes for United States placer exploration: U.S. Geological Survey Bulletin 2097, 9 p., 2 plates.

Guégin, Michel, and Cardarelli, François, 2007, Chemistry and mineralogy of titania-rich slags, Part 1- Hemoilmenite, sulfate, and upgraded titania slags: Mineral Processing and Extractive Metallurgy Review, v. 28, p. 1-58.

Gunson Resources Limited, 2013, Coburn project (mineral sand) - Western Australia: Gunson Resources Limited company Web site, accessed March 25, 2013, at http://www.gunson.com.au.

Guo, Quiju, Cheng, Jianping, and Chen, Yong, 2005, Dose evaluation of indoor thoron progeny in some areas in China, in McLaughlin, J.P., Simopoulus, S.E., and Steinhäusler, F., eds., The Natural Radiation Environment VII, Proceedings of an International Symposium, Rhodes, Greece, 20-24 May 2002: Amsterdam, Elsevier, p. 506-511. 
Haq, B.U., Hardenbol, Jan, and Vail, P.R., 1987, Chronology of fluctuating sea levels since the Triassic: Science, v. 235, no. 4793, p. 1156-1167.

Hedrick, J.B., 1997, Rare-earth metals: U.S. Geological Survey Minerals Yearbook, p. 61.1-61.6.

Henderson, J.R., Stromquist, A.A., and Jespersen, Anna, 1966, Aeromagnetic map of parts of the Mother Lode gold and Sierra Foothills copper mining districts, California, and its geologic interpretation: U.S. Geological Survey Geophysical Investigations Map GP-561, 4 p. pamphlet, 1 sheet, scale 1:62,500.

Herath, J.W., 1990, Sri Lanka’s minerals and national development: Industrial Minerals, no. 270, p. 133-135.

Hewson, G.S., 1997, Inhalation and retention of thorium dusts by mineral sands workers: Annals of Occupational Hygiene, v. 41, Supplement 1, p. 92-98.

Hoatson, D.M., Jaireth, Subhash, and Miezitis, Yanis, 2011, The major rare-earth-element deposits of AustraliaGeological setting, exploration, and resources: Geoscience Australia, 204 p.

Hou, Baohong, Alley, N.F., Frakes, L.A., Stoian, L., and Crowley, W.M., 2006, Eocene stratigraphic succession in the Eucla basin of South Australia and correlation to major regional sea-level events: Sedimentary Geology, v. 183, nos. 3-4, p. 297-319.

Hou, Baohong, Frakes, L.A., Sandiford, M., Worrall, L., Keeling, J., Alley, N.F., 2008, Cenozoic Eucla basin and associated paleovalleys, southern Australia-Climatic and tectonic influences on landscape evolution, sedimentation and heavy mineral accumulation: Sedimentary Geology, v. 203, nos. 1-2, p. 112-130.

Hou, Baohong, Keeling, John, Reid, Anthony, Fairclough, Martin, Warland, Ian, Belousova, Elena, Frakes, Larry, and Hocking, Roger, 2011, Heavy mineral sands in the Eucla basin, southern Australia-Deposition and province-scale prospectivity: Economic Geology, v. 106, no. 4, p. 687-712.

Hou, Baohong, and Warland, Ian, 2005, Heavy mineral sands potential of the Eucla basin in South Australia: MESA Journal, v. 37, p. 4-12.

Hunt, G.R., 1982, Spectroscopic properties of rocks and minerals, in Carmichael, R.S., ed., Handbook of physical properties of rocks, v. I: Boca Raton, Fla., CRC Press, p. 295-385.

Hunter, R.E., 1968, Heavy minerals of the Cretaceous and Tertiary sands of extreme southern Illinois: Illinois Geological Survey Circular 428, 22 p.
Iluka Resources, 2013a, Operations: Iluka Resources company Web site, accessed March 13, 2013, at http://www.iluka. com/company-overview/operations.

Iluka Resources, 2013b, Mining and processing: Iluka Resources company Web site, accessed March 31, 2013, at http://www.iluka.com/company-overview/mineral-sandsindustry-overview/mining-processing.

Image Resources NL, 2013, Image Resources: Image Resources company Web site, accessed March 25, 2013, at http://www.imageres.com.au/.

Indian Rare Earths Limited, 2013, Unit profile: Indian Rare Earths Limited company Web site, accessed April 8, 2013, at http://www.irel.gov.in/scripts/unit.asp.

Indústrias Nucleares do Brasil SA (INB), 2013, INB BuenaMineral treatment unit: Indústrias Nucleares do Brasil SA Web site, accessed September 16, 2014, at http://www.inb. gov.br/pt-br/WebForms/default.aspx.

Jackson, W.D., and Christiansen, Grey, 1993, International strategic minerals inventory summary report-Rare-earth oxides: U.S. Geological Survey Circular 930-N, 68 p.

Kenmare Resources plc, 2013, Welcome to Kenmare Resources plc: Kenmare Resources plc company Web site, accessed March 28, 2013, at http://www.kenmareresources.com/.

The Kerala Minerals \& Metals Limited, 2013, KMML: The Kerala Minerals \& Metals Limited company Web site, accessed March 28, 2013, at http://www.kmml.com/.

Komar, P.D., and Wang, Chi, 1984, Processes of selective grain transport and the formation of placers on beaches: Journal of Geology, v. 92, no. 6, p. 637-655.

Korneliussen, Are, McEnroe, S.A., Nilsson, L.P., Schiellerup, Henrik, Gautneb, Hårvard, Meyer, G.B., and Størseth, L.R., 2000, An overview of titanium deposits in Norway: Norges Geologiske Underskøleske Bulletin 436, p. 27-38.

Lanka Minerals Sands Limited, 2013, Welcome to Lanka Mineral Sands: Lanka Mineral Sands Limited company Web site, accessed April 10, 2013, at http://www. lankamineralsands.com/.

Lawton, D.C, and Hochstein, M.P., 1980, Physical properties of titanomagnetite sands: Geophysics, v. 45, no. 3, p. 394-402.

Lees, Brian, 2006, Timing and formation of coastal dunes in northern and eastern Australia: Journal of Coastal Research, v. 22, no.1, p. 78-89.

Leonardos, O.H., Jr., 1974, Origin and provenance of fossil and Recent monazite deposits in Brazil: Economic Geology, v. 69 , no. 7 , p. 1126-1128. 
Lewis, J.W., 1980, Environmental aspects of mineral sand mining in Australia: Minerals and the Environment, v. 2, p. 145-158.

Light, T.D., Cady, J.W., Weber, F.R., McCammon, R.B., and Rinehart, C.D., 1987, Sources of placer gold in the southern part of the White Mountains Recreation Area, east-central Alaska, in Hamilton, T.D., and Galloway, J.P., eds., Geologic studies in Alaska by the U.S. Geological Survey during 1986: U.S. Geological Survey Circular 998, p. 67-69.

Loferski, P.J., 2013a, Zirconium and hafnium, in 2011 minerals yearbook: U.S. Geological Survey, p. 85.1-85.8. Available at http://minerals.usgs.gov/minerals/pubs/ commodity/zirconium/.

Loferski, P.J., 2013b, Zirconium and hafnium, in Mineral commodity summaries 2013: U.S. Geological Survey, p. 190-191. Available at http://minerals.usgs.gov/minerals/ pubs/commodity/zirconium/.

Lubke, R.A., and Avis, A.M., 1998, A review of the concepts and application of rehabilitation following heavy mineral dune mining: Marine Pollution Bulletin, v. 37, p. 546-557.

Luepke, Gretchen, 1984, Stability of heavy minerals in sediments: New York, N.Y., Van Nostrand Reinhold Company, Scientific and Academic Editions, 306 p.

Mackey, T.S., 1994, Upgrading ilmenite into a high-grade synthetic rutile: Journal of Metals, v. 46, p. 59-64.

Mackie, William, 1923, The principles that regulate the distribution of particles of heavy minerals in sedimentary rocks, as illustrated by the sandstones of north-east of Scotland: Edinburgh Geological Society Transactions, v. 11, p. 138-164.

MacNeil, F.S., 1950, Pleistocene shore lines in Florida and Georgia: U.S. Geological Survey Professional Paper 221-F, p. $95-107,7$ plates.

Mahadevan, V., Narayana Das, G.R., and Nagaraja, N.N., 1958, Prospecting and evaluation of beach placers along the Coastal Belt of India, in United Nations International Conference on the Peaceful Uses of Atomic Energy, 2d, Geneva, September 1-13, 1958-Volume 2, Survey of raw material resources, Proceedings: Geneva, United Nations Publication, p. 103-106.

Malhotra, S.K., 2012, Press release no. 10/2012-Export of monazite from India, the facts: Government of India, Department of Atomic Energy, Public Awareness Division, 2 p. Accessed May 1, 2012, at https://dae.nic.in/ writereaddata/pr070512.pdf.
Marques, E.D., Tubbscv, D., Gomes, O.V.O., and Silva-Filho, E.V., 2012, Influence of acid sand pit lakes in surrounding groundwater chemistry, Sepetiba sedimentary basin, Rio de Janeiro, Brazil: Journal of Geochemical Exploration, v. 112, p. 306-321.

Martin, Richard, 2012, Super fuel-Thorium, the green energy source for the future: New York, N.Y., Palgrave Macmillan, $262 \mathrm{p}$.

McCullough, C.D., and Lund, M.A., 2006, Opportunities for sustainable mining pit lakes in Australia: Mine Water and the Environment, v. 25, p. 220-226.

McKellar, J.B., 1975, The eastern Australian rutile province, in Knight, C.I., ed., Economic geology of Australia and Papau New Guinea: Australian Institute of Mining and Metallurgy, Volume 1-Metals, p. 1055-1062.

Mertie, J.B., Jr., 1975, Monazite placers in the southeastern Atlantic States: U.S. Geological Survey Bulletin 1390, 41 p.

Mineral Deposits Limited, 2013, Grand Côte: Mineral Deposits Limited company Web site, accessed March 14, 2013, at http://www.mineraldeposits.com.au/grande-cote-mineralsands/.

Moll, J.B., 1992, Studies on dune rehabilitation techniques for mined areas at Richards Bay, Natal: Grahamstown, South Africa, Rhodes University, Master's thesis, 128 p.

Morton, A.C., and Hallsworth, C.R., 1999, Processes controlling the composition of heavy mineral assemblages in sandstones: Sedimentary Geology, v. 124, p. 3-29.

Mukherjee, T.K., 2007, Thorium resources in India, its mining, separation and chemical processing: International Atomic Energy Agency (IAEA) technical meeting on "Thorium based fuels and fuel cycle options for pressurized heavy water cooled reactors, light water reactors and high temperature gas-cooled reactors," October 22-25, 2007, Istanbul, Turkey.

Murphy, Philip, and Frick, Louise, 2006, Titanium, in Kogel, J.E., Trivedi, N.C., Barker, J.M., and Krukowski, S.T., eds., Industrial minerals \& rocks - Commodities, markets, and uses (7th ed.): Littleton, Colo., Society for Mining, Metallurgy, and Exploration, Inc. (SME), p. 987-1003.

Murty, V.G.K., Gurung, R., Upadhyay, R., and Asokan, S., 2007, Tata Steel's Titania project-Challenges in slimes disposal, in International Heavy Minerals Conference "Back to Basics," 6th: The Southern African Institute of Mining and Metallurgy, p. 111-118.

MZI Resources Limited, 2013, Welcome to MZI Resources Limited: MZI Resources Web site, accessed March 25, 2013, at http://mzi.com.au/. 
Neiheisel, James, 1962, Heavy-mineral investigations of Recent and Pleistocene sands of the lower coastal plain of Georgia: Geological Society of America Bulletin, v. 73, no. 3, p. 365-374.

Neiheisel, James, 1976, Heavy minerals in aeroradioactive high areas of the Savannah River flood plain and deltaic plain: South Carolina Division of Geology Geologic Notes, v. 20 , no. 2 , p. $45-51$.

Nie, Junsheng, Peng, Wenbin, Pfaff, Katharina, Möeller, Andreas, Garzanti, Eduardo, Andò, Sergio, Stevens, Thomas, Bird, Anna, Chang, Hong, Song, Yougui, Liu, Hanpin, Ji, Shunchuan, 2013, Controlling factors on heavy mineral assemblages in Chinese loess and Red Clay: Palaeogeography, Palaeoclimatology, Palaeoecology, v. 381-382, p. 110-118.

Nordstrom, D.K., and Alpers, C.N., 1999, Geochemistry of acid mine waters, in Plumlee, G.S., and Logsdon, M.J., eds., The environmental geochemistry of mineral deposits, part A. Processes, techniques, and health issues: Reviews in Economic Geology, vol. 6A, p. 133-160.

O'Driscoll, Mike, 1988, Rare earths-Enter the dragon: Industrial Minerals, v. 254, p. 21-55.

Olson, J.C., and Overstreet, W.C., 1964, Geologic distribution and resources of thorium: U.S. Geological Survey Bulletin 1204, $61 \mathrm{p}$.

Oresome Australia Pty. Limited, 2013, Welcome: Oresome Australia Party Limited Web site, accessed March 25, 2013, at http://www.oresome.com.au/main/page_home.html.

Orris, G.J., and Grauch, R.I., 2002, Rare earth element mines, deposits, and occurrences: U.S. Geological Survey OpenFile Report 02-189, version 1. Available at http://pubs.usgs. gov/of/2002/of02-189/.

Overstreet, W.C., 1967, The geologic occurrence of monazite: U.S. Geological Survey Professional Paper 530, 327 p., 2 plates.

Overstreet, W.C., White, A.M., Whitlow, J.W., Theobald, P.K., Jr., Caldwell, D.W., and Cuppels, N.P., 1968, Fluvial monazite deposits in the southeastern United States: U.S. Geological Survey Professional Paper 568, 85 p., 9 plates.

Paine, Mark, 2005, Sedimentology of the Bondi Main heavy mineral beach placer deposit, Murray basin, southeastern Australia: Sedimentary Geology, v. 174, nos. 3-4, p. 177-195.

Panda, N.K., Rajagopalan, V., and Ravi, G.S., 2003, Rareearth-element geochemistry of placer monazites from Kalingapatnam Coast, Srikakulam district, Andhra Pradesh: Journal of the Geological Society of India, v. 62, no. 4, p. 429-438.
Paschoa, A.S., and Steinhäusler, F., 2013, Terrestrial, atmospheric, and aquatic natural radioactivity, in Paschoa, A.S, and Steinhäusler, F., eds., Radioactivity in the environment: Technologically Enhanced Natural Radiation, v. 17, p. 29-85.

Peterson, C.D., Komar, P.D., and Scheidegger, K.F., 1986, Distribution, geometry, and origin of heavy mineral placer deposits on Oregon beaches: Journal of Sedimentary Petrology, v. 56, no. 1, p. 67-77.

Pillai, P.M.B., 2008, Naturally occurring radioactive material (NORM) in the extraction and processing of rare earths, in International Symposium on Naturally Occurring Radioactive Material (NORM V), Seville, Spain, March 19 - 22, 2007, Proceedings: p. 197-219.

Pirkle, E.C., Pirkle, W.A., and Yoho, W.H., 1974, The Green Cove Springs Boulougne heavy-mineral sand deposits of Florida: Economic Geology, v. 69, p. 1129-1137.

Plumlee, G.S., 1999, The environmental geology of mineral deposits, in Plumlee, G.S., and Logsdon, M. J., eds., The environmental geochemistry of mineral deposits, part A. Processes, techniques, and health issues: Society of Economic Geologists, Reviews in Economic Geology, vol. 6A, p. 71-116.

Plumlee, G.S., and Logsdon, M.J., 1999, An earth-system science toolkit for environmentally friendly mineral resource development, in Plumlee, G.S., and Logsdon, M. J., eds., The environmental geochemistry of mineral deposits, part A. Processes, Techniques, and health issues: Society of Economic Geologists, Reviews in Economic Geology, vol. $6 \mathrm{~A}$, p. 1-27.

Plumlee, G.S., and Nash, J.T., 1995, Geoenvironmental models of mineral deposits-Fundamentals and applications, in du Bray, E.A., ed., Preliminary compilation of descriptive geoenvironmental mineral deposit models: U.S. Geological Survey Open-File Report 95-831, p. 1-9.

Puffer, J.H., and Cousminer, H.L., 1982, Factors controlling the accumulation of titanium-iron oxide-rich sands in the Cohansey Formation, Lakehurst area, New Jersey: Economic Geology, v. 77, no. 2, p. 379-391.

Reid, Anthony, Keeling, John, Boyd, Doug, Belousova, Elena, and Hou, Baohong, 2013, Source of zircon in world class heavy mineral placer deposits of the Cenozoic Eucla basin, southern Australia from LA-ICPMC U/Pb geochronology: Sedimentary Geology, v. 286-287, p. 1-19.

Richards Bay Minerals, 2013, History: Richards Bay Minerals company Web site, accessed April 4, 2013, at http://www.rbm.co.zalabout/rbm_history.php. 
Rio Tinto, 2013, About QMM: Rio Tinto company Web site, accessed March 28, 2013, at http://www. riotintomadagascar.com/english/aboutQMM.asp.

Robson, D.F., and Sampath, N., 1977, Geophysical response of heavy-mineral sand deposits at Jerusalem Creek, New South Wales: BMR Journal of Australian Geology and Geophysics, v. 2, no. 2, p. 149-154.

Rollinson, G.K., Andersen, J.C.O., Stickland, R.J., Boni, Maria, and Fairhurst, Rob, 2011, Characterization of non-sulphide zinc deposits using QEMSCAN ${ }^{\circledR}$ : Minerals Engineering, v. 24, no. 8, p. 778-787.

Roy, P.S., 1999, Heavy mineral beach placers in southeastern Australia-Their nature and genesis: Economic Geology, v. 94 , no. 4 , p. $567-588$.

Roy, P.S., and Whitehouse, John, 2003, Changing Pliocene sea levels and formation of heavy mineral beach placers in the Murray basin, southeastern Australia: Economic Geology, v. 98 , no. 5, p. $975-983$.

Roy, P.S., Whitehouse, John, Cowell, P.J., and Oakes, Geoff, 2000, Mineral sands occurrences in the Murray basin, southeastern Australia: Economic Geology, v. 95, no. 5, p. $1107-1128$.

Rubey, W.W., 1933, The size distribution of heavy minerals within a water-laid sandstone: Journal of Sedimentary Petrology, v. 3, p. 3-29.

Rupasinghe, M.S., and Dissanayake, C.B., 1984, The rareearth element abundance in the sedimentary gem deposits of Sri Lanka: Lithos, v. 17, no. 4, p. 329-342.

Rupasinghe, M.S., Gocht, W., and Dissanayake, C.B., 1983, The genesis of thorium-rich monazite placer deposits in Sri Lanka: Journal of the National Science Council of Sri Lanka, v. 11, no. 1, p. 99-110.

Sabedot, Sydney, and Sampaio, C.H., 2006, Remoção de inclusões minerais em zircões: Revista da Escola de Minas (Ouro-Preto), v. 59, no. 2, p. 153-158.

Sabha, Lok, 2011, Deposits of rare earths: Government of India Department of Atomic Energy, Parliament Questions, Lok Sabha Winter Session 2011 Questions and Answers, Question 300, accessed December 3, 2012, at http://www. dae.nic.in/?q=node/466.

Sahu, K.K., Alex, T.C., Mishra, D., and Agrawal, A., 2006, An overview on the production of pigment grade titania from titania-rich slag: Waste Management and Research, v. 24, p. 74-79.

Salisbury, J.W., Walter, L.S., Vergo, N., and D'Aria, D.M., 1991, Infrared (2.1-25 $\mu \mathrm{m})$ spectra of minerals: Baltimore, Md., The Johns Hopkins University Press, 267 p.
Saviour, M.N., 2012, Environmental impact of soil and sand mining - A review: International Journal of Science, Environment and Technology, v. 1, p. 125-134.

Shah, A.K., and Harris, M.S., 2012, Shipboard surveys track magnetic sources in marine sediments-Geophysical studies of the Stono and North Edisto Inlets near Charleston, South Carolina: U.S. Geological Survey Open-File Report 2012-1112.

Shah, A.K., Vogt, P.R., Rosenbaum, J.G., Newell, Wayne, Cronin, T.M., Willard, D.A., Hagen, R.A., Brozena, John, and Hofstra, Albert, 2012, Shipboard magnetic field "noise" reveals shallow heavy mineral sediment concentrations in Chesapeake Bay: Marine Geology, v. 303-306, p. 26-41.

Sheffield Resources Limited, 2013, Projects overview: Sheffield Resources Limited company Web site, accessed March 25, 2013, at http://www.sheffieldresources.com.au.

Shepherd, M.S., 1990, Eneabba heavy mineral sand placers, in Hughes, F.E., ed., Geology and mineral deposits of Australia and Papua New Guinea: Parkville, Victoria, Australasian Institute of Mining and Metallurgy, p. 1591-1594.

Sibelco Australia, 2013, Mining operations: Sibelco Australia company Web site, accessed March 25, 2013, at http://www. sibelco.com.au/crl/index.html.

Siddiquie, H.N., Gujar, A.R., Hashimi, N.H., and Valsangkar, A.B., 1984, Superficial mineral resources of the Indian Ocean: Deep Sea Research Part A. Oceanographic Research Papers, v. 31, nos. 6-8, p. 763-812.

Sierra Rutile Limited, 2013, The deposit-World class deposit: Sierra Rutile Limited company Web site, accessed April 4, 2013, at http://www.sierra-rutile.com/the-deposit.aspx.

Staatz, M.H., Armbrustmacher, T.J., Olson, J.C., Brownfield, I.K., Brock, M.R., Lemons, J.F., Jr., Coppa, L.V., and Clingan, B.V., 1979, Principal thorium resources in the United States: U.S. Geological Survey Circular 805, 42 p.

Staatz, M.H., Hall, R.B., Macke, D.L., Armbrustmacher, T.J., and Brownfield, I.K., 1980, Thorium resources of selected regions in the United States: U.S. Geological Survey Circular 824, $32 \mathrm{p}$.

Teakle, Mark, and Mudge, Stephen, 2003, Geophysical exploration for heavy-mineral sands near Mindarie, South Australia: Australian Society of Exploration Geophysicists (ASEG) Extended Abstracts 2003, no. 3, p. 249-255.

Trimex Industries, 2013, Trimex Industries operations: Trimex Industries company Web site, accessed March 28, 2013, at http://www.trimexgroup.com/operations.asp.

Tronox, 2013, Our company: Tronox Company Web site, accessed April 4, 2013, at http://www.tronox.com/ourcompany/. 
Tse, P.K., 2011, China's rare-earth industry: U.S. Geological Survey Open-File Report 2011-1042, 11 p. Available only on-line at http://pubs.usgs.gov/of/2011/1042/.

Tyler, R.M., and Minnitt, R.C.A., 2004, A review of subSaharan heavy mineral sand deposits-Implications for new projects in southern Africa: The Journal of The South African Institute of Mining and Metallurgy, v. 104, no. 2, p. 89-99.

van Aarde, R.J., Ferreira, S.M., Kritzinger, J.J., van Dyk, P.J., Vogt, M., and Wassenarr, T.D., 1996, An evaluation of habitat rehabilitation on coastal dune forests in northern Kwazulu-Natal, South Africa: Restoration Ecology, v. 4, p. 334-345.

Van Etten, E.J.B., McCullough, C.D., and Lund, M.A., 2011, Sand mining restoration on the Swan Coastal Plain using topsoil-Learning from monitoring of previous rehabilitation attempts, in International Heavy Minerals Conference 2011, 8th, Perth, Australia, 5-6 October, Carlton South, Victoria, Australia, Australasian Institute for Mining and Metallurgy (AusIMM), Proceedings: p. 323-338.

Velta LLC, 2013, The company: Velta LLC company Web site, accessed April 4, 2013, at http://www.velta-ua.com/velta/ index_gb.cfm.

Verhulst, Dirk, Sabacky, B.J., Spitler, T.M., and Prochazka, J.A., 2003, New process for the production of nano-sized $\mathrm{TiO}_{2}$ and other ceramic oxides by spray hydrolysis: Reno, Nevada, Altair Nanomaterials Inc.

Victoria Department of Sustainability and Development, 2006, Assessment guidelines for the Donald Mineral Sands Project Environment Effects Statement (EES): Accessed May 31, 2013, at http://www.dpcd.vic.gov.au/ planning/environment-assessment/projects/donald-mineralsands\#main_content.

Wilcox, J.T., 1971, Preliminary investigation of heavy minerals in the McNairy Sand of west Tennessee: Nashville, Tenn., Tennessee Department of Conservation Division of Geology, Report of Investigations 31, 11 p.

Williams, Lloyd, 1967, Heavy minerals in South Carolina: Columbia, S.C., South Carolina State Development Board, Division of Geology, Bulletin 35, 35 p.

Winkler, C.D., and Howard, J.D., 1977, Correlation of deformed shorelines on the southern Atlantic Coastal Plain: Geology, v. 5, no. 2, p. 123-127.

Woodruff, L.G., Nicholson, S.W., and Fey, D.L., 2013, A deposit model for magmatic iron-titanium-oxide deposits related to Proterozoic massif anorthosite plutonic suites: U.S. Geological Survey Scientific Investigations Report 2013-5091, 47 p.
World Titanium Resources, 2013, Creating a tier one mineral sands company: World Titanium Resources company Web site, accessed March 14, 2013, at http://www.worldtitaniumresources.com/.

Wynn, J.C., 1988, Titanium geophysics - The application of induced polarization to sea-floor mineral exploration: Geophysics, v. 53, no. 3, p. 386-401.

Wynn, J.C., Grosz, A.E., and Foscz, V.M., 1985, Induced polarization and magnetic response of titanium-bearing placer deposits in the southeastern United States: U.S. Geological Survey Open-File Report 85-756, 41 p.

Publishing support provided by:

Denver Publishing Service Center

For more information concerning this publication, contact:

Center Director, USGS Central Mineral and

Environmental Resources Science Center

Box 25046, Mail Stop 973

Denver, CO 80225

(303) 236-1562

Or visit the Central Mineral and Environmental Resources Science Center Web site at: http://minerals.cr.usgs.gov/ 


\section{$\frac{\mathbb{3}}{3}$}

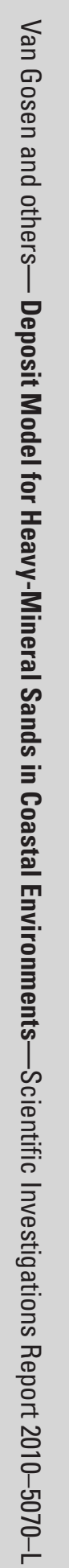

